\title{
Understanding process controls on groundwater recharge variability across Africa through Recharge Landscapes
}

Charles West ${ }^{1}$, Rafael Rosolem ${ }^{1,2}$, Alan M. MacDonald ${ }^{3}$, Mark O. Cuthbert ${ }^{4,5}$ and Thorsten Wagener ${ }^{1,6}$

1 Civil Engineering, University of Bristol, Bristol, United Kingdom

2 Cabot Institute for the Environment, University of Bristol, Bristol, United Kingdom

3 British Geological Survey, Lyell Centre, Edinburgh EH14 4AP, United Kingdom

4 School of Earth and Environmental Sciences, Cardiff University, Park Place, Cardiff, CF10 3AT, United Kingdom

5 School of Civil and Environmental Engineering, The University of New South Wales, Sydney, Australia

6 Institute for Environmental Science and Geography, University of Potsdam, 14476 Potsdam, Germany

This is a non-peer reviewed preprint submitted to EarthArXiv. This article has recently been submitted to Journal of Hydrology for peer review. 
24 Groundwater is critical in supporting current and future reliable water supply throughout Africa. Although continental maps of groundwater storage and recharge have been developed, we currently lack a clear understanding on how the controls on groundwater recharge vary across the entire continent. Reviewing the existing literature, we synthesize information on reported groundwater recharge controls in Africa. We find that 15 out of 22 of these controls can be characterised using global datasets. We develop 11 descriptors of climatic, topographic, vegetation, soil and geologic properties using global datasets, to characterise groundwater recharge controls in Africa. These descriptors cluster Africa into 15 Recharge Landscape Units for which we expect recharge controls to be similar. Over $80 \%$ of the continents land area is organized by just nine of these units. We also find that aggregating the Units by similarity into four broader Recharge Landscapes (Desert, Dryland, Wet tropical and Wet tropical forest) provides a suitable level of landscape organisation to explain differences in ground-based long-term mean annual recharge and recharge ratio estimates. Furthermore, wetter Recharge Landscapes are more efficient in converting rainfall to recharge than drier Recharge Landscapes as well as having higher annual recharge rates. In Dryland Recharge Landscapes, we found that annual recharge rates largely varied according to mean annual precipitation, whereas recharge ratio estimates increase with increasing monthly variability in P-PET. However, we were unable to explain why ground-based estimates of recharge signatures vary across other Recharge Landscapes, in which there are fewer ground-based recharge estimates, using global datasets alone. Even in dryland regions, there is still considerable unexplained variability in the estimates of annual recharge and recharge ratio, stressing the limitations of global datasets for investigating ground-based information. 
47 Keywords: Groundwater recharge, Africa, recharge controls, ground-based estimates, landscapes, comparative hydrology

51 With an estimated storage of 0.66 million $\mathrm{km}^{3}$, groundwater is the largest store of freshwater in Africa and its development is fundamental for securing current and future water supply (MacDonald et al., 2012). With such volume, groundwater in Africa exceeds the estimated annual volumes of streamflow by a factor of 100 (MacDonald et al., 2012). High inter-annual variability of streamflow in dryland river basins s the challenges of securing water supply solely from surface water sources (Conway et al. 2009; Siam and Eltahir 2017; Sidibe et al. 2019). For example, in the Sahel and Southern Africa, standard deviations in annual river flows can be up to $100 \%$ of the long term mean flow (Dettinger and Diaz 2000), and Siam and Eltahir, (2017) have already shown that inter-annual streamflow variability has increased with climate change in the Nile basin. In agriculture-dependent economies such as those in rural Africa, economic growth is hampered by such uncertain water supply due to the strong inter-annual variability in rainfall; for example Ethiopia may have 38\% less economic growth than it would have under average rainfall conditions (Hall et al. 2014). Poor investments in reservoir infrastructure in much of Africa mean that per capita storage is low and does not sufficiently alleviate the problem of variability (Hall et al. 2014). Furthermore, in regions where streamflow predominantly varies at decadal timescales, such as in the Sahel, persistent dry periods can lead to long-term shortages in surface water supply (Conway et al. 2009; Sidibe et al. 2019). Increased use of groundwater could therefore reduce vulnerability to climate driven surface water shortages, particularly in rural communities (Calow et al., 1997; 
Lapworth et al., 2013; MacDonald \& Calow, 2009) and generally improve water accessibility (Robins et al., 2006).

Yet, our understanding of the spatial variability of groundwater recharge processes across Africa remains limited, constraining our ability to plan for the sustainable use of this resource (MacDonald et al., 2021). Recent studies have tried to overcome this problem in multiple ways: [1] Scaling up knowledge from a limited number of detailed local studies. Cuthbert et al. (2019b) used multi-decadal groundwater level timeseries in conjunction with local knowledge to develop site specific conceptual models which allowed the authors to highlight a relationship between climate and recharge frequency, sensitivity to precipitation and dominant recharge mechanisms. However, this approach relies heavily upon rare long-term data as well as local knowledge and therefore it is challenging to transfer findings to larger scales or different regions. [2] Most studies have based their continental scale estimates on process-based models. Global scale hydrological models and land surface models can estimate groundwater recharge rates across large spatial domains (Reinecke et al. 2021). However, these models largely rely upon global datasets for their parameterisation with only very limited levels of evaluation against hydrologic fluxes - especially fluxes rarely estimated locally such as groundwater recharge (Bierkens, 2015; Telteu et al., 2021; Wagener et al., 2021). Global models thus far also include only a limited number of process representations and neglect regionally dominant controls, such as karst (Hartmann et al., 2015; Hartmann et al., 2014) or dryland-specific hydrological processes (Quichimbo et al. 2021). [3] Most recently, MacDonald et al. (2021) used 134 ground-based annual recharge estimates compiled from the literature along with global datasets to develop a continental statistical model. This model enabled them to estimate long-term groundwater recharge rates across Africa using mean annual precipitation without qualitative inclusion of different recharge processes. 
Here, we want to improve our understanding of the hydrologic controls governing the spatial variability of groundwater recharge (MacDonald et al., 2021) across Africa, utilizing the wider knowledge on controlling processes gained throughout the literature. We specifically aim to answer three questions: (i) What are the dominant controls on groundwater recharge already identified across Africa in previous studies? (ii) Using global datasets only, what descriptors of controlling processes can we define, and which regions of Africa should have similar recharge controls when clustered using these descriptors? (iii) How do these regions for which we expect similar controls compare to ground-based recharge observations? Due to the limited amount of ground-based data on groundwater recharge in Africa, we adopt an approach which builds strongly on our a priori understanding of recharge controls in Africa identified from the literature. In doing so we build on previous efforts by Scanlon et al. (2006) who synthesized qualitative local knowledge of recharge processes for the world's dry regions. In keeping with the database compiled by (MacDonald et al., 2021), we only review the controls on recharge which is distributed throughout the landscape and exclude recharge from large discrete features such as rivers or lakes. We follow the ideas of Winter's concept of hydrological landscapes (Winter 2001) and define Recharge Landscape Units to represent areas for which we expect similar recharge controls. We then compare these areas against an openly available, comprehensive and thoroughly quality assured dataset of ground-based recharge estimates in Africa, recently published by MacDonald et al. (2021).

\section{Review of process controls on groundwater recharge across Africa}

Most of the existing knowledge base on groundwater recharge processes, controls and rates in Africa comes from a relatively small number of case studies investigating recharge at the field, catchment, or sometimes regional scale. These studies use a wide range of methods to 
understand recharge processes throughout the continent, with approaches often varying according to environmental setting, data availability and the objective of the individual studies (MacDonald et al. 2021). Details of the strengths and weaknesses of the different methods can be found in Scanlon et al. (2002) and Healy (2010). We organize the review of controls into four domains: climate and weather, topography, landcover/use, and soils and geology. The aim of this review is firstly to identify dominant controls on groundwater recharge, and secondly to understand whether these controls have clear positive or negative relationships with groundwater recharge, or if their relationship with recharge is ambiguous.

We are considering processes that govern the potential recharge of an aquifer, which can be less than the actual recharge since some potential recharge is rejected if the aquifer is full. We show a summary of this review in Figure 1. An extended version of the review can be found in the supplemental information.

\section{Climate and weather}

Annual scale components of the water-energy balance are a first order control on the spatial variability of groundwater recharge (Kim and Jackson, 2012; Mohan et al., 2018; Cuthbert et al., 2019b; MacDonald et al., 2021), as they control the quantity of water available to be partitioned into groundwater recharge, as well as the energy available to partially control atmospheric losses (Budyko, 1974). Hence studies in Africa show variability of annual recharge rates along a climate gradient, largely defined by precipitation due to the generally high levels of energy available (MacDonald et al. 2021). In an upland catchment of Cameroon where rainfall exceeds $3000 \mathrm{~mm} /$ year, estimated recharge rates exceed 900 $\mathrm{mm} /$ year (Kamtchueng et al. 2015), in comparison to recharge rates between $160 \mathrm{~mm} / \mathrm{year}$ and $330 \mathrm{~mm} /$ year in the Ethiopian Highlands where annual rainfall is approximately 1300 mm/year (Azagegn et al. 2015; Banks et al. 2021; Demlie 2015). Groundwater resources throughout the deserts, which receive very little annual rainfall (Nicholson 2000), are 
recharged at rates below $5 \mathrm{~mm} /$ year (Foster et al., 1982; Dabous and Osmond, 2001; Zouari et al., 2011), or may not even be actively recharged (Befus et al. 2017). In these regions deep 'fossil' groundwaters recharged prior to the Holocene dominate aquifer stores (Sturchio et al., 2004; Guendouz et al., 2006; Abotalib et al., 2016; Jasechko et al., 2017).

Groundwater recharge volumes are often biased towards the rainy season as elevated rainfall is required to overcome high rates of evapotranspiration (Bromley et al., 1997; Demlie et al., 2007; Walraevens et al., 2009; Mechal et al., 2015), and greater monthly and daily precipitation intensity leads to a more efficient conversion of rainfall to recharge (Jasechko and Taylor 2015; Owor et al. 2009; Taylor and Howard 1996). Groundwater level observations in the Makutapora wellfield, Tanzania, suggest that recharge is dependent upon months with the most extreme $\left(>95^{\text {th }}\right.$ percentile) rainfall (Taylor et al. 2013) often enhanced by the El Nino Southern Oscillation and the Indian Ocean Dipole. However, the multiple climate oscillations known to affect climate patterns in Africa (Brown et al., 2010) can have opposing effects in different parts of the continent (Nicholson and Kim 1997). Nonetheless, wetting and drying cycles are being reflected in observed groundwater hydrographs throughout Africa (Taylor et al., 2013; Cuthbert et al., 2019b; Kolusu et al., 2019), showing both seasonally extreme recharge events as well as recharge events which are more episodic in nature.

Episodic rainfall events are particularly important in arid landscapes where recharge often depends upon a small number of days of intense rainfall (Vogel and Van Urk, 1975; Mazor et al., 1977; Van Tonder and Kirchner, 1990; Nkotagu, 1996; De Vries et al., 2000; Xu and Beekman, 2003; Wanke et al., 2008). Döll and Fiedler (2008) stressed the importance of heavy rainfall events in semi-arid and arid regions as they modelled groundwater recharge globally, applying a rainfall threshold of $10 \mathrm{~mm} /$ day to drylands, below which they assumed recharge would not occur. They identified this threshold via an independent analysis of 25 
chloride profile estimates of annual recharge distributed throughout the world as well as regional model estimates of recharge in Death Valley, California.

In summary, annual and seasonal precipitation as well as heavy rainfall events have a positive relationship with groundwater recharge in Africa - largely driving inter- and intra-annual recharge variability, while the amount of energy available from radiation has a negative relationship with groundwater recharge. However, the influence of large-scale climate oscillations on groundwater recharge in Africa is less clear as their effect on climate patterns vary regionally.

\section{Topography}

Topographic slope controls the movement of water across the land surface and therefore controls water infiltration into the subsurface and groundwater recharge, with gentler slopes promoting more recharge than steeper slopes (Simmers 1990). The role of slope in controlling groundwater recharge has been discussed throughout many different regions of Africa, including Ethiopia (Gebreyohannes et al. 2013), Nigeria (Abdullateef et al. 2021; Fashae et al. 2014), Botswana (Lentswe and Molwalefhe 2020) and Algeria (Boufekane et al., 2020). Yet interestingly, McKenna and Sala (2018) found that recharge beneath flat playas in the south-western United States is greater when they are surrounded by steeper slopes which promote greater run-on onto the playa.

In dry regions, intense rainfall events are important drivers of focused recharge through flash flooding (Sultan et al. 2000) and the formation of ephemeral water bodies and depression storage (Lehner and Döll, 2004), i.e. in areas where water accumulates on the land surface. In Africa's dry regions, alluvial aquifers underlying dry riverbeds are recharged episodically or perhaps seasonally by river transmission losses following heavy rainfall (Tantawi, ElSayed and Awad, 1998; Sultan et al., 2000; Gheith and Sultan, 2002; Benito et al., 2010; 
Walker et al., 2019; Seddon et al., 2021). These storms can activate focused recharge mechanisms despite negligible diffuse recharge in interfluve regions due to high evaporation (Favreau et al. 2009). In endoreic arid basins, surface water can also accumulate in salt pans which typically occupy topographic depressions (Lehner and Döll 2004). (De Vries et al., 2000) use chloride profiles to show that in the eastern fringes of the Kalahari Desert, recharge is enhanced under these pans, with estimated annual rates of $50 \mathrm{~mm}$ in comparison to $7 \mathrm{~mm}$ for the surrounding landscape.

Therefore, slope generally has a negative relationship with groundwater recharge since it will provide an easier flow path for water to move downhill, whereas topographic depressions have a positive relationship with (focused) groundwater recharge because they allow water to accumulate.

\section{Landcover/use}

Landcover and use varies considerably across the African continent. Bare soils (33\% of Africa's land area) occupy most of northern Africa as well as parts of southern and eastern Africa, whilst grasslands (15.4\%), shrublands (13.4\%) and agriculture (11.6\%) are largely distributed throughout the Sahel and Southern and Eastern Africa, and forests and woodland (26\%) spread across western, central and south-eastern regions (Mayaux et al., 2004;

Tsendbazar et al., 2017; Xiong et al., 2017). These vegetation patterns influence the spatial variability of groundwater recharge (Kim and Jackson 2012) through their control over transpiration, interception and soil evaporation fluxes (Gordon et al., 2005; Schlesinger and Jasechko, 2014; Good et al., 2015).

An estimated $7 \%$ of the continent's precipitation returns to the atmosphere via interception evaporation, mostly occurring in the densely forested regions of Central Africa where this flux can exceed 10\% of the precipitation input (Miralles et al. 2010; Zhang et al. 2016; Zheng 
et al. 2017). Globally, we could not find any studies directly discussing the relationship between rainfall interception and groundwater recharge. However, it seems reasonable to assume that by limiting the amount of precipitation reaching the land surface, interception consequently reduces groundwater recharge.

An estimated $49 \%$ and $21 \%$ of precipitation over Africa returns to the atmosphere via transpiration and bare soil evaporation, respectively (Zhang et al. 2016). The bulk of continental transpiration is associated with the tropical forests (Gordon et al., 2005; Good et al., 2015), where tall vegetation with deep rooting systems increases the capacity of root-zone moisture storage (Nijzink et al. 2016) and the access to deeper groundwater (Barbeta and Peñuelas 2017). When investigating groundwater recharge at regional and catchment scales, studies often find that recharge rates are lower in areas which are forested than in areas which are unforested or have bare soils (Gebreyohannes et al. 2013; Houston 1982; Howard and Karundu 1992; Stone and Edmunds 2012). Furthermore, the presence of woodland or forest can restrict groundwater recharge to years of particularly high rainfall, even when recharge in grass, crop or unvegetated parts of the catchment occurs annually (Houston 1982; Howard and Karundu 1992). In the Kalahari Desert, dense bush and tree savannah is believed to transpire much of the annual rainfall during the long dry season, leading to very little recharge (De Vries et al., 2000; Sibanda et al., 2009). Similarly, chloride profiles in Senegal, suggest that groundwater recharge rates decline as vegetation density increases (Edmunds and Gaye 1994). Land clearing, often for agricultural expansion, can also enhance groundwater recharge rates by reducing evapotranspiration (Taylor and Howard 1996; Været et al. 2009).

Land clearing for agriculture does not only affect recharge through changes to evapotranspiration, it can also alter the mechanisms through which recharge occurs, by altering soil surface properties (Wirmvem et al. 2015) as well as runoff run-on processes 
242 (Leduc et al., 2001; Leblanc et al., 2008; Favreau et al., 2009; Ibrahim et al., 2014; Wirmvem et al., 2015). Agricultural land adjacent to many of Africa's largest lakes and rivers is regularly equipped for irrigation (Siebert et al. 2015). Excess irrigation water can infiltrate into the soil and percolate to the aquifer, increasing groundwater recharge rates (Bouimouass et al. 2020; Scanlon et al. 2007). Nonetheless, as irrigation technologies become more efficient, recharge via irrigation excesses is expected to decline (Scanlon et al. 2007).

Urban settings only account for less than $0.01 \%$ of the African landscape (Zhou et al. 2015). Although, urbanisation is typically perceived as reducing groundwater recharge by reducing the permeable surface area, recharge rates in urban areas can be as high as or even higher than nearby rural areas (Lerner 2002; Sharp 2010). Urbanization can dampen existing recharge mechanisms, but it can also introduce new mechanisms such as localised recharge where there is little drainage infrastructure (Lerner 2002; Sharp 2010), as well as leakages from on-site sanitation (Foster et al., 1999; Diouf, 2012; Lapworth et al., 2017) and piped distribution networks if such water supply is available.

In short, we find that the transpiration and canopy storage controls of different landcovers show a negative relationship with groundwater recharge, whereas the additional supply of water to agricultural land through irrigation has a positive relationship with recharge. Effects of urbanisation on groundwater recharge on the other hand are more ambiguous.

Soils with larger sand fractions are more permeable and support higher recharge rates than finer clay soils. In a global scale meta-analysis of recharge estimates, Kim and Jackson (2012) show that on average sandy soils are 50\% more efficient in converting water input into groundwater recharge. Similar results are found at regional and catchment scales in 
the sand fraction is a more dominant component of the soil (Abdalla 2009; Butterworth et al. 1999; Edmunds and Gaye 1994). Lower recharge rates are found in clayey soils as the vertical percolation of water through the soil profile is restricted (Attandoh et al. 2013; Edmunds et al. 1992) and soil moisture is more exposed to evapotranspiration (Mensah et al, 2014; Yidana and Koffie, 2014; Kotchoni et al., 2018).

However, soil texture alone fails to recognise structural soil properties which enable infiltration via preferential flow paths which bypass the soil matrix (Beven and Germann 1982). Macropores in the soil structure allow infiltration to bypass vegetation rooting zones and impermeable soil layers (De Vries et al., 2000; Mazor, 1982; Van Tonder \& Kirchner, 1990; Xu \& Beekman, 2003) and facilitate recharge in conditions which would otherwise be prohibitive. These preferential flow paths are an important mechanism for groundwater recharge across a range of contrasting environmental settings. In the Botswanan Kalahari Desert, semi-arid Tanzania and the tropical highlands of Ethiopia, the contribution of preferential flows to groundwater recharge is approximately $24 \%, 60 \%$ and $36 \%$, respectively (Demlie et al. 2007; Nkotagu 1996; de Vries and Gieske 1990).

Rock fracturing (Nkotagu, 1996; Xu and Beekman, 2003; Adams et al., 2004; Kebede et al., 2005; Kamtchueng et al., 2015) and vertical conduits in karstic rock (Farid et al., 2014; Hartmann et al., 2014, 2017; Chemseddine et al., 2015; Ayadi et al., 2018; Leketa et al., 2019) also provide preferential flow paths for groundwater recharge. In dry landscapes such as the Kalahari Desert, rock fracturing at bedrock outcrops and isolated rock formations called inselbergs (Burke 2003) can locally enhance groundwater rates (Mazor, 1982; Butterworth et al., 1999; Brunner et al., 2004; Wanke et al., 2008). The distribution and geometry of the superficial geology can also have a marked impact on recharge pathways and rates in conjunction with the underlying bedrock and distribution of stream networks (Zarate 
et al. 2021). Similar observations have been made regarding focused recharge opportunities for water in karstic regions (Hartmann et al. 2017).

292 Soil perturbations such as crusting, cementation, compaction, weathering, and tillage can also 293 have a significant impact on recharge rates. Whilst studies mostly find that soil crusting 294 (Favreau et al. 2009; Jacks and Traoré 2014; Wakindiki and Ben-Hur 2002), cementation (Nash et al., 1994; De Vries et al., 2000; Xu and Beekman, 2003; Francis et al., 2007) and compaction (Hamza and Anderson, 2005; du Toit et al., 2009) reduce the permeability of soil layers and hence reduce groundwater recharge, the effects of deeply weathered soils known as laterites (Bromley et al., 1997; Rueedi et al., 2005; Cuthbert and Tindimugaya, 2010; Bonsor et al., 2014) and agricultural tilling practices (Abu-Hamdeh, 2004; Osunbitan et al., 2005; Spaan et al., 2005; Strudley et al., 2008; Thierfelder and Wall, 2009; Abidela Hussein et al., 2019) on recharge are much less clear.

Therefore, in summation we find that, soil grain sizes, bedrock outcrops and properties which promote preferential flow paths, such as soil macropores, rock fractures and karst geology, have a positive relationship with groundwater recharge. Some soil perturbations such as compaction, cementation and crusting have a negative relationship with groundwater recharge, whereas others, including tilling and soil laterization, have a less clear relationship with recharge.

Interactions between controls

Up to now we have largely looked at landscape properties and their control over recharge processes independently, in reality, groundwater recharge is a function of the interactions between these controls. Hence at the continental scale, we would typically expect to find some of the lowest recharge rates in areas with the most freely draining soils, as these regions also have the lowest precipitation volumes. By identifying patterns in the landscape, i.e. 
climate, topography, vegetation, soils and geology, we can begin to conceptualise recharge processes of different environmental settings found in Africa. We can find these patterns as landscapes are continuously co-evolving (Troch et al. 2013) via an array of physical and biological processes which effect the uplift and deformation of bedrock and the erosion, transportation and deposition of sediments (Dietrich and Perron 2006; Reinhardt et al. 2010). This co-evolution, explains why we typically expect to find certain landscapes throughout the continent, including rainforests, tropical woodlands and savannas and deserts.

We often regard climate as an external force driving the hydrological system, but it also controls the spatial and temporal patterns of landcover (Zhou et al., 2014; Hawinkel et al., 2016; Bouvet et al., 2018; Measho et al., 2019; Ndehedehe et al., 2019) and soils (Jenny 1941; Towett et al. 2015). Climate and vegetation patterns as well as soil properties are also strongly affected by local topography. In mountainous areas we see vegetation becoming shorter and less dense above the treeline, as temperatures decline and thinning soils make ground conditions less stable (Harsch et al., 2009; Egli and Poulenard, 2016). Increased 2009; Steward et al., 2012; Ndehedehe et al., 2019; Grodek et al., 2020). 


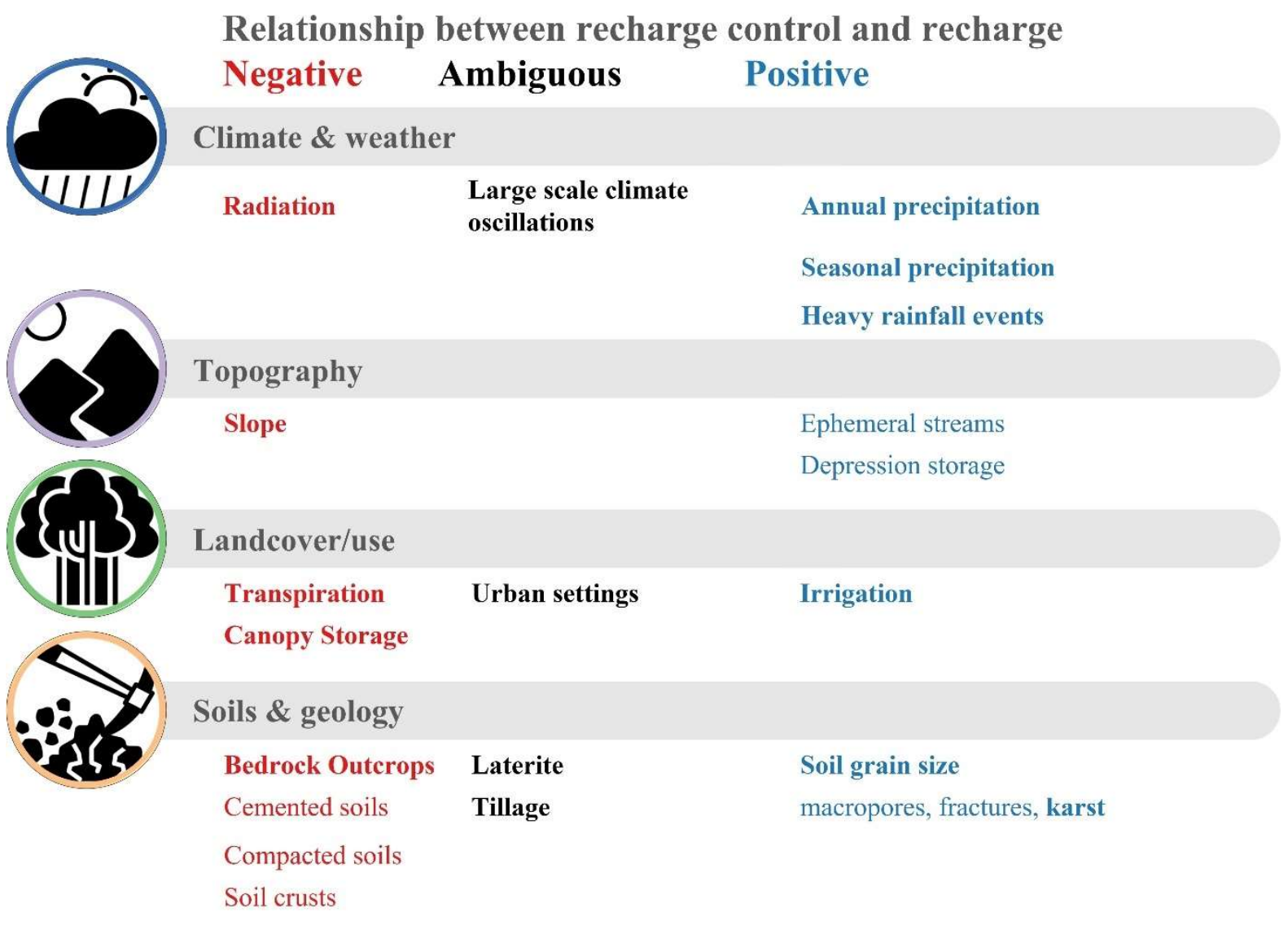

Figure 1. Summary of groundwater recharge controls for Africa identified in the literature. Controls are colour coded according to their relationship with recharge with red and blue representing negative and positive relationships, respectively. Bold font highlights controls which we can characterise using global datasets.

\section{Materials and methods}

\subsection{Global Datasets}

We used nine global datasets to characterize the previously identified groundwater recharge

controls. Furthermore, controls were only integrated into our classification if the literature indicated it had a clear positive or negative relationship with groundwater recharge and it could be characterized using global datasets. The datasets used and the indices calculated are summarized in Table 1.

Indices describing annual and seasonal climate attributes mostly characterise first-order estimates of the water potentially available for groundwater recharge (P-PET) annually and 
seasonally as well as its variability. This also builds on previous work by Wolock et al. (2004) who used P-PET as the climatic index to delineate hydrological landscapes in the

United States. We characterised heavy rainfall across Africa using a threshold of $10 \mathrm{~mm} /$ day.

Several studies in Africa (Döll and Fiedler 2008; Owor et al. 2009; Taylor and Howard 1996)

357

have found annual recharge has a stronger correlation with the average volume of rainfall per year on days with at least $10 \mathrm{~mm}$ of rain, than with mean annual precipitation and hence we selected this as threshold for heavy rainfall in Africa. Though we acknowledge the rainfall threshold for recharge occurrence likely varies across the continent. We characterized the influence of landcover on groundwater recharge via transpiration and canopy storage processes, by attributing vegetation specific transpiration coefficients to a landcover dataset and by looking at the Leaf Area Index, respectively. This approach is also often taken when parameterizing these processes in continental scale hydrological modelling (Telteu et al., 2021). To avoid having multiple indices to describe soil textures we instead calculated the ratio of soils which promote infiltration (i.e., sand) to those which restrict infiltration (i.e., silt and clay) (Saxton et al., 1986; Wösten et al., 2001). We used the depth to bedrock dataset of (Pelletier et al. 2016) to highlight bedrock outcrop regions and the world map of carbonate rock outcrops (Williams and Ford 2006) to highlight the extent of carbonate rock outcrops.

Table 1. Details of the recharge control indices we defined to characterise recharge controls across Africa and the global datasets we used to calculate them.

\begin{tabular}{|c|c|c|c|c|c|}
\hline Attribute & Description & Units & Period & Data source & Reference \\
\hline \multicolumn{6}{|c|}{ Climate attributes } \\
\hline P-PET & $\begin{array}{l}\text { Mean annual } \\
\text { precipitation minus } \\
\text { mean annual PET. }\end{array}$ & $\mathrm{mm} /$ year & $1979-2015$ & $\begin{array}{l}\text { 1. MSWEP } \\
\text { v1.2 } \\
\text { (Precipitation) }\end{array}$ & $\begin{array}{l}\text { 1. (Beck et al. } \\
2017)\end{array}$ \\
\hline $\begin{array}{l}\text { P-PET in } \\
\text { season }\end{array}$ & $\begin{array}{l}\text { Mean annual volume } \\
\text { of precipitation in } \\
\text { excess to PET in } \\
\text { months considered } \\
\text { in-season. A month is } \\
\text { considered in-season } \\
\text { when P exceeds PET. }\end{array}$ & $\mathrm{mm} /$ year & $1979-2015$ & $\begin{array}{l}\text { Spatial res.: } \\
0.25^{\circ} \\
\text { Temporal res.: } \\
\text { Daily } \\
\text { 2. CRU v4 } \\
\text { (PET) }\end{array}$ & $\begin{array}{l}\text { 2. (Harris et al., } \\
\text { 2020) }\end{array}$ \\
\hline
\end{tabular}




\begin{tabular}{|c|c|c|c|c|c|}
\hline$\sigma(\mathrm{P}-\mathrm{PET})$ & $\begin{array}{l}\text { The standard } \\
\text { deviation of monthly } \\
\text { P-PET }\end{array}$ & $\mathrm{mm} / \mathrm{month}$ & $1979-2015$ & \multirow{2}{*}{$\begin{array}{l}\text { Spatial res.: } \\
0.5^{\circ} \\
\text { Temporal res.: } \\
\text { Monthly }\end{array}$} & \\
\hline P10 & $\begin{array}{l}\text { The average volume } \\
\text { of rainfall per year on } \\
\text { days with at least } 10 \\
\text { mm of rain. }\end{array}$ & $\mathrm{mm} /$ year & $1979-2015$ & & \\
\hline \multicolumn{6}{|c|}{ Topography attributes } \\
\hline Slope & $\begin{array}{l}\text { Geodesic slope of the } \\
\text { DEM using a } 3 \text { by } 3 \\
\text { moving window. }\end{array}$ & Degrees & $\begin{array}{c}\text {-(Lehner, } \\
\text { Verdin, and } \\
\text { Jarvis } \\
2013) \\
\end{array}$ & $\begin{array}{l}\text { HydroSHEDS } \\
\text { Spatial res.: } \\
15 \text { arc seconds }\end{array}$ & $\begin{array}{l}\text { (Lehner et al., } \\
\text { 2013) }\end{array}$ \\
\hline \multicolumn{6}{|l|}{ Landcover/use } \\
\hline Kveg & $\begin{array}{l}\text { Vegetation } \\
\text { coefficient related to } \\
\text { transpiration. } \\
\text { Vegetation-specific } \\
\text { annual values (L. J. } \\
\text { Gordon et al. 2005) } \\
\text { applied to a } \\
\text { landcover } \\
\text { classification. Mean } \\
\text { value from 1992- } \\
2005 \text {. }\end{array}$ & - & $1992-2015$ & $\begin{array}{l}\text { ESA-CCI } \\
\text { v2.0.7 } \\
\text { Spatial res.: } \\
\text { 300m } \\
\text { Temporal res.: } \\
\text { Yearly }\end{array}$ & $\begin{array}{l}\text { (Defourny et al. } \\
\text { 2017) }\end{array}$ \\
\hline LAI & $\begin{array}{l}\text { Mean leaf area index } \\
\text { (based on } 12 \text { monthly } \\
\text { means from 1981- } \\
\text { 2015) }\end{array}$ & - & $1981-2015$ & $\begin{array}{l}\text { GIMMS- } \\
\text { LAI3g v2 } \\
\text { Spatial res.: } \\
0.25^{\circ} \\
\text { Temporal res.: } \\
\text { Monthly }\end{array}$ & $\begin{array}{l}\text { (Mao and Yan. } \\
\text { 2019) }\end{array}$ \\
\hline Irrigation & $\begin{array}{l}\text { Area equipped for } \\
\text { irrigation multiplied } \\
\text { by the fractional area } \\
\text { actually irrigated. }\end{array}$ & $\mathrm{km}^{2}$ & 2005 & $\begin{array}{l}\text { Global Map of } \\
\text { Irrigation } \\
\text { Areas } \\
\text { Spatial res.: } 5 \\
\text { arc minutes }\end{array}$ & $\begin{array}{l}\text { (Siebert et al., } \\
\text { 2013) }\end{array}$ \\
\hline \multicolumn{6}{|l|}{ Soil attributes } \\
\hline $\begin{array}{l}\text { Sand / (Clay + } \\
\text { Silt) }\end{array}$ & $\begin{array}{l}\text { The ratio of sand } \\
(>0.05 \mathrm{~mm}) \text { to silt } \\
(0.002-0.05 \mathrm{~mm}) \text { and } \\
\text { clay }(<0.002 \mathrm{~mm}) \text { in } \\
\text { the fine earth fraction } \\
\text { of the top } 2 \mathrm{~m} \text { of the } \\
\text { soil profile. } \\
\text { Proportions of each } \\
\text { soil texture are by } \\
\text { weight. Take the } \\
\text { depth weighted } \\
\text { harmonic mean } \\
\text { across intervals of } 0- \\
5 \mathrm{~cm}, 5-15 \mathrm{~cm}, 15- \\
30 \mathrm{~cm}, 30 \mathrm{~cm}-60 \mathrm{~cm}, \\
60-100 \mathrm{~cm}, 100- \\
200 \mathrm{~cm} .\end{array}$ & - & - & $\begin{array}{l}\text { SoilGrids } 250 \mathrm{~m} \\
\text { Spatial res.: } \\
250 \mathrm{~m}\end{array}$ & $\begin{array}{l}\text { (Hengl et al. } \\
\text { 2017) }\end{array}$ \\
\hline \multicolumn{6}{|c|}{ Geology attributes } \\
\hline $\begin{array}{l}\text { Depth to } \\
\text { bedrock }\end{array}$ & $\begin{array}{l}\text { Average soil and } \\
\text { sedimentary deposit } \\
\text { thickness. Maximum } \\
\text { of } 50 \mathrm{~m} \text {. }\end{array}$ & $\mathrm{m}$ & - & $\begin{array}{l}\text { Gridded } \\
\text { Thickness of } \\
\text { Soil, Regolith } \\
\text { and }\end{array}$ & $\begin{array}{l}\text { (Pelletier et al. } \\
\text { 2016) }\end{array}$ \\
\hline
\end{tabular}




\begin{tabular}{|c|c|c|c|c|c|}
\hline & & & & $\begin{array}{l}\text { Sedimentary } \\
\text { Deposit Layers } \\
\text { Spatial res.: } 30 \\
\text { arc seconds }\end{array}$ & \\
\hline Karst & $\begin{array}{l}\text { Extent of carbonate } \\
\text { rock outcrop areas. }\end{array}$ & - & - & $\begin{array}{l}\text { World Map of } \\
\text { Carbonate } \\
\text { Rock Outcrops } \\
\text { V3.0 }\end{array}$ & $\begin{array}{l}\text { (Williams and } \\
\text { Ford 2006) }\end{array}$ \\
\hline
\end{tabular}

\subsection{Ground-based annual recharge and recharge ratio estimates}

375 We used the database compiled by MacDonald et al. (2021) of long-term mean annual recharge estimates compiled from case studies in the literature. We selected this database

377 above other meta-datasets (Moeck et al. 2020; Mohan et al. 2018) because of its focus on

378 Africa, the thorough quality assurance conducted throughout its compilation, and the

379 additional meta-data provided. Additional screening removed data points where the site co-

380 ordinates and date of the study period were not provided. Finally, we removed estimates dated prior to 1979 or after 2015, as they would not correspond to the timing of the climate datasets we used. Ultimately, we were left with 129 ground-based estimates of annual groundwater recharge distributed across Africa. 111 of these sites/studies also reported corresponding mean annual precipitation rates, so we could estimate long-term mean recharge ratios at these locations (Figure 2). 

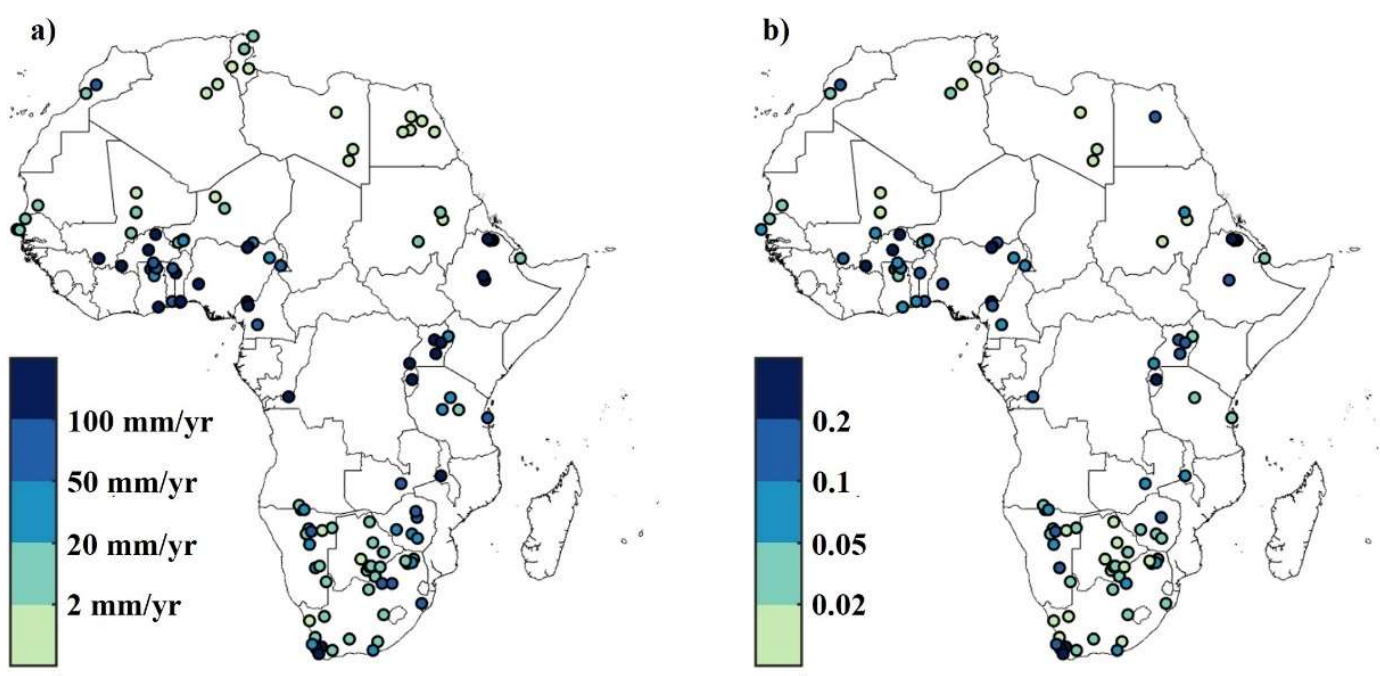

Figure 2. The remaining annual recharge and recharge ratio estimates collected from case studies in the literature by

388 MacDonald et al. (2021), after initial screening of the data. The recharge ratio is defined as the fraction of precipitation being converted to recharge (recharge / precipitation).

\subsection{Fuzzy Clustering}

To delineate regions with expected similar recharge control indices (i.e., Recharge Landscape Units) we use a fuzzy c-means clustering algorithm (Bezdec 1981). This fuzzy clustering algorithm allows for pixels to belong to multiple units simultaneously, albeit with varying degrees of membership, thus enabling us to study the gradual transition between units (e.g., reflecting different landscapes). The degree of overlap in membership allowed us to determine the uniqueness of each delineated Recharge Landscape Unit. The degree of membership is dependent upon how close in value each pixel's recharge control indices are to the centroid of each unit, which is regarded as being representative for a unit. Membership scores vary from 0 to 1 , with 0 representing no similarity and 1 suggesting the pixel's recharge control indices are equal to the values of the unit's centroid. Further details on the algorithm and on application details are provided in the supplemental material. Ultimately, we attributed each pixel to the unit with which it has the highest degree of membership, which we refer to as its primary unit.

\subsection{Random Forests}


We used classification-based Random Forests to expand our classification for recharge controls in Africa to the rest of the world. Random Forests is a machine learning algorithm which combines multiple trees to produce an ensemble of predictions (Breiman 2001; Breiman et al. 1984), which link predictor variables (recharge control indices) to a response (Recharge Landscape Units). Each individual tree develops rules for predicting responses which are structured as a binary decision tree composing of nodes and branches. At each node a conditional binary split is applied to one of the predictor variables. The split forms two branches which link to nodes in the overlying stratum. This splitting continues until the terminal node (the leaf) is met and the outcome is predicted. Each classification tree in the ensemble model is trained on observations (Pixels of classification for recharge controls in Africa) which were randomly selected with replacement from a sub-sample of $70 \%$ of the total observations ('in-bag' observations). The random forest model consists of 25 trees each with a maximum of 400 decision splits. Increasing the number of trees or decision splits did not significantly improve model performance. Addor et al., (2018) previously used Random Forests to predict observed streamflow signatures across the USA and Stein et al., (2021) used random forests to explore how climate and catchment attributes influence flood generating processes.

\section{Results}

\subsection{Recharge Landscape Units outline regions with similar recharge}

\section{controls in Africa}

Based on our review in section 2, we defined and calculated 11 indices to characterise the different controls on distributed groundwater recharge we identified in our review (Figure 1). To avoid using redundant information for each control, we checked the correlations between each of the indices initially considered and removed indices such that none of the indices for 
a given control had Pearson correlation coefficients greater than or equal to 0.7 with one

430 another (see supplemental information) (Dormann et al. 2013). 
a)

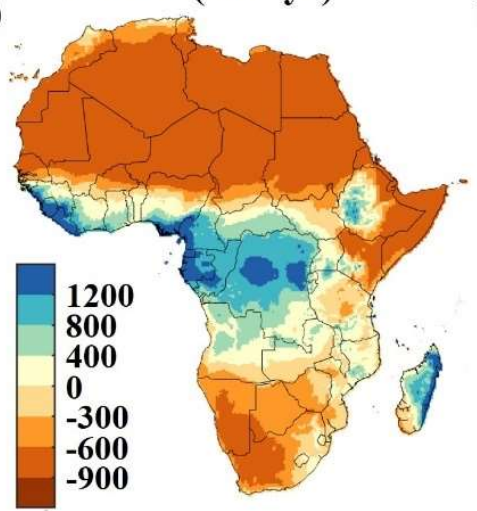

b)

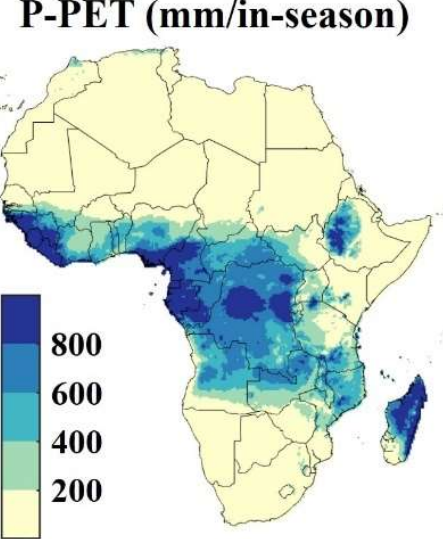

c)

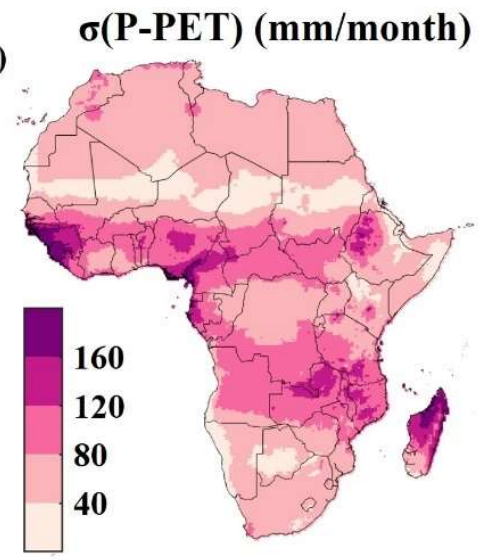

f)

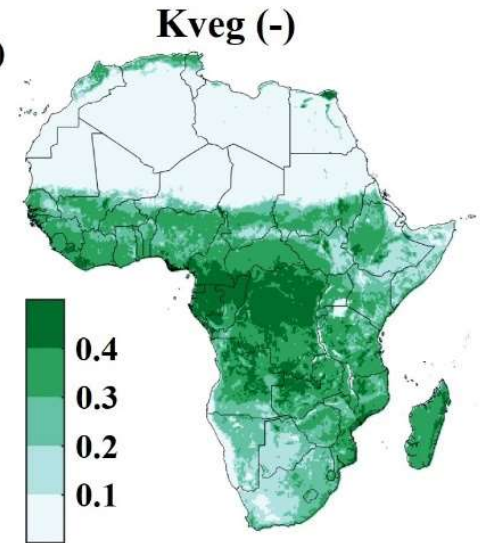

i)

$$
\text { Sand / (Clay + Silt) }
$$

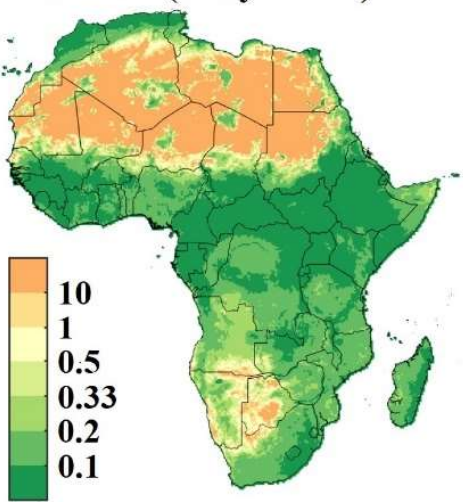

g)

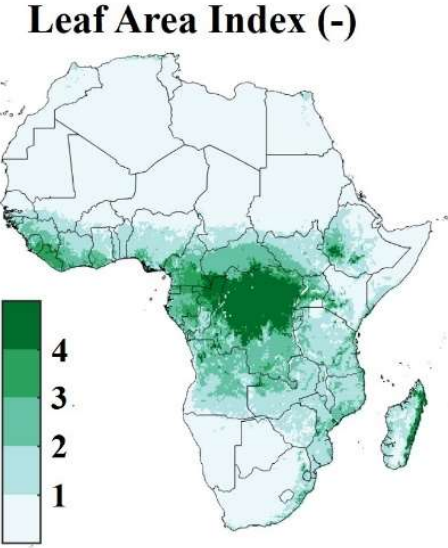

Depth to Bedrock (m)

j)

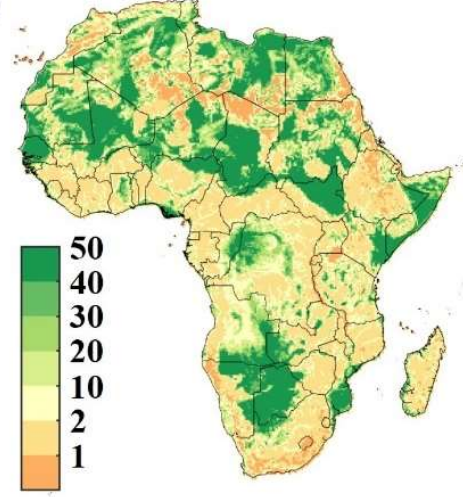

h)

Karst

)
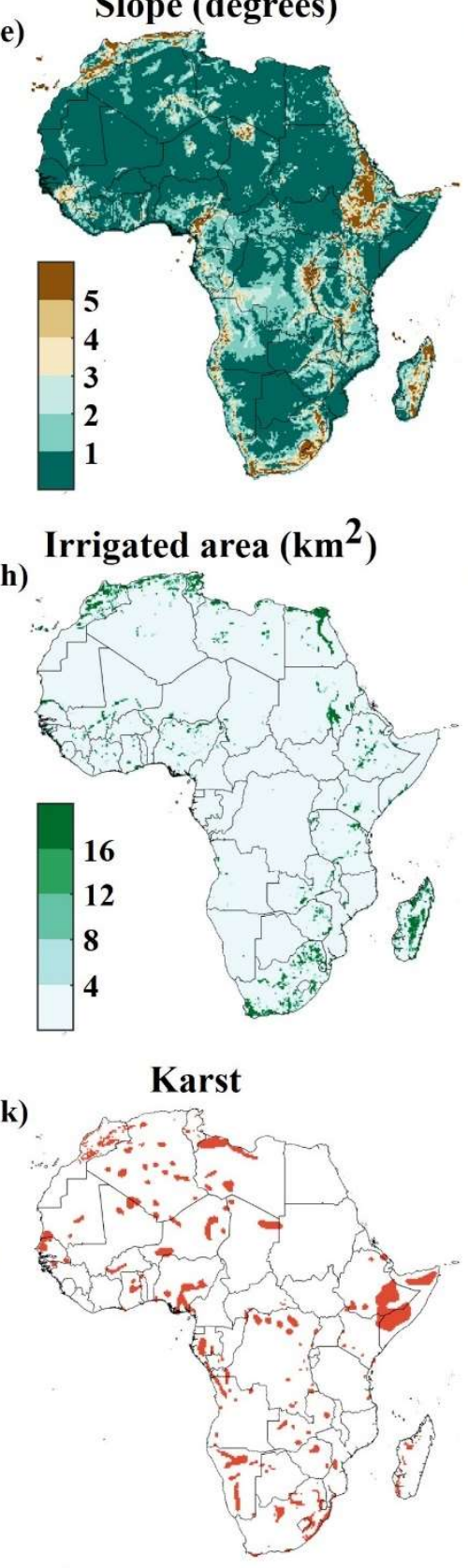

Irrigated area $\left(\mathrm{km}^{2}\right)$ 
Figure 3. 11 recharge control indices characterising controls identified in the literature using global datasets. a) P-PET; b) PPET in-season; c) б(P-PET); d) P10; e) Slope; f) Kveg; e) Leaf Area Index; h) Irrigated area; i) Sand / (Clay + Silt); j) Depth to bedrock; k) Karst. The definitions of each index the datasets used for their characterisation are stated in Table 1.

The cluster analysis combines the 11 indices into 15 Recharge Landscape Units with similar recharge control indices of which 9 cover over $80 \%$ of the African land area (Figure 4$)$. We initially identified 14 units using fuzzy clustering, as additional units did not greatly reduce the dissimilarity within individual units. The $15^{\text {th }}$ unit which delineates potential karst regions was manually superimposed. Even though we expect recharge to vary significantly between the different settings in which karst is found, we delineate the group as a whole, because we expect the recharge mechanism associated to karst environments to be a dominant control on recharge processes. We can see the continent has been roughly organised into very dry regions in the north and south of the continent and wetter regions spanning from West Africa down through Central Africa towards Mozambique and Madagascar. Even though the spatial organisation of the units suggest proximity is a reasonable indicator for similarity, we do find regions with similar recharge control indices which are also far away from each other. For example, hyper arid regions with shallow soils can be found along Namibia's coastline as well as the coastlines of Egypt and Sudan and throughout the Sahara Desert (unit 5) and extremely wet regions can be found on the coast of West Africa and eastern Madagascar (unit 7). Likewise dry highland regions with high slope can be found in South Africa, the East African Rift, Ethiopian Highlands and in the Atlas Mountains (unit 4) and flat regions with thick soil profiles can be found throughout the Sahel, South Sudan and the Kalahari basin (unit 13). In contrast, we also find Recharge Landscape Units which appear to represent unique and spatially concentrated areas, such as the Congo Basin Rainforest (units 9 and 14), as well as regions where properties appear more diverse with multiple units appearing within smaller areas, such as Madagascar and Ethiopia. 


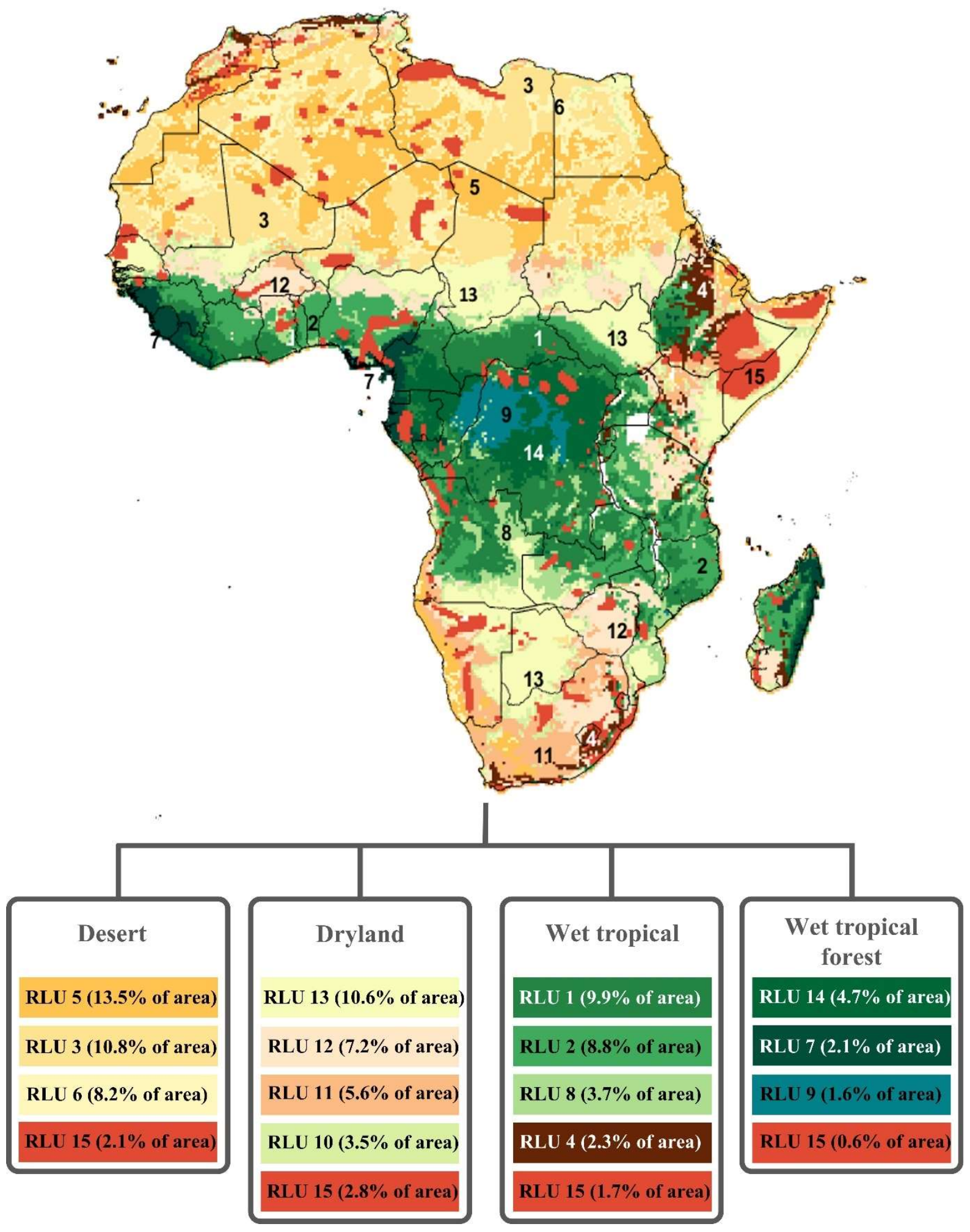

Figure 4. Map of the 15 Recharge Landscape Units of our classification for a priori understanding of recharge controls in Africa. We group the Recharge Landscape Units into broader groups of similar units which we call Recharge Landscapes. 
We found that grouping Recharge Landscape Units into broader Recharge Landscapes

462

463

464

465

466

467

468

469

470

471

472

473

474

475

476

477

478

479

480

481

482

483

484

485

suitably organises the African landscape into regions with noticeably different distributions of long-term average annual recharge and recharge ratio (Figure 6). These broader Recharge Landscapes also aggregate Recharge Landscape Units with similar recharge control indices, as shown by the boxplots in Figure 5. For each index, boxplots are organized by the median values of each unit, ordered from left to right in descending order. In Dryland and Wet tropical Recharge Landscapes, we see that climate and weather, landcover and soil texture indices transition smoothly across all units. Units within Wet tropical forest Recharge Landscape are typically associated to high Kveg and Leaf Area index values and fine soil textures, whilst units of the Desert Recharge Landscape have low Kveg and Leaf Area values as well as predominantly sandy soils. Similarly, most units have similar topographic slopes except for unit 3, 4 and 13 which represent highland and flat plain regions. There is a clear divide in the depth of soils in each of the units, with six of the units showing deeper soil profiles and 8 showing a tendency towards shallow soils. We can see that unit 15 which represents karst regions occurs in a wide range of different climate, topographical, landcover and soil settings. Irrigated areas do not contribute to large areas of any of our Recharge Landscape Units.

Desert Recharge Landscapes could only be further differentiated by their depth to bedrock, while other landscape types were dis-aggregated by climate seasonality, slope, landcover and slope, as well as the depth to bedrock. Desert Recharge Landscape Units are differentiated according to depth to bedrock is less than $13.5 \mathrm{~m}$ (unit 5), where the bedrock depth is between $13.5 \mathrm{~m}$ and $33.9 \mathrm{~m}$ (unit 6) and where the depth to bedrock is greater than $33.9 \mathrm{~m}$ (unit 3). This reflects differences in topography throughout Desert Recharge Landscapes, as mountainous Desert Recharge Landscapes with greater slopes also have smaller bedrock depths. Dryland Recharge Landscapes are also largely dis-aggregated according to the depth 


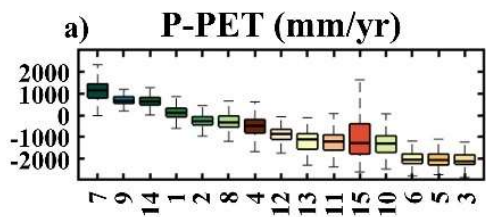

b) P-PET (mm/In-season)
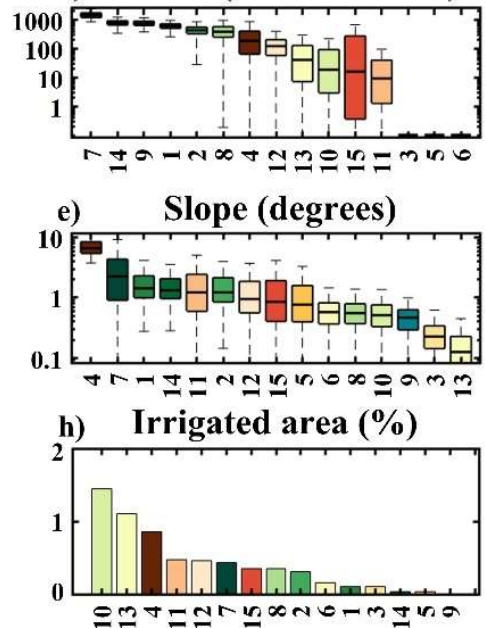

k) Depth to Bedrock (m)

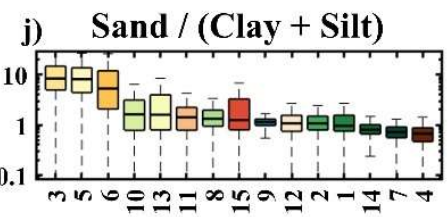

Recharge Landscape Units

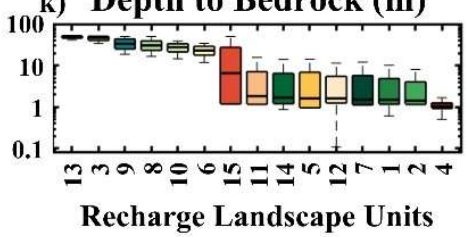

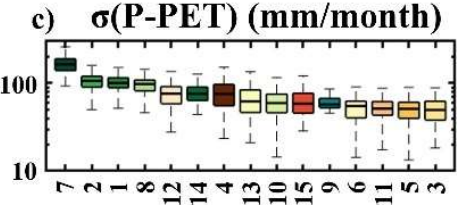
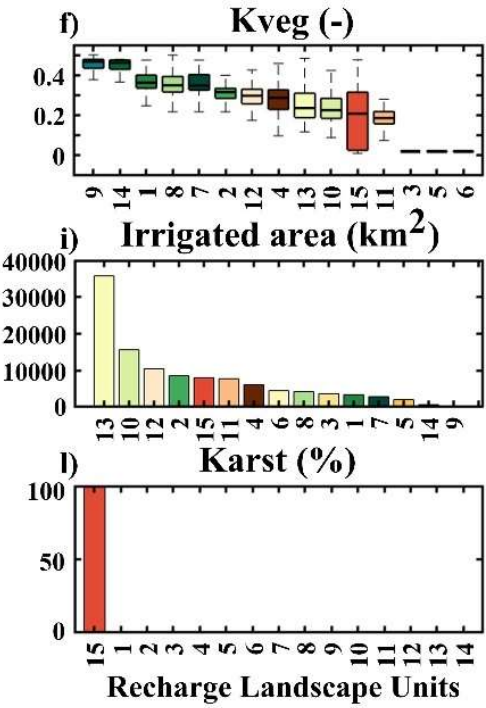

489

Figure 5. Boxplots showing the index values in each of the Recharge Landscape Units we identified. Boxplots are organised from left to right in descending order of the median values in each unit. We show irrigated area as both the total area irrigated within the Recharge Landscape Units (h) and as a percentage of the areas for each Recharge Landscape Unit (i).

Ground-based estimates of annual recharge (recharge ratio) are bias towards drier settings with 20 (15), 66 (58), 28 (25) and 3 (3) data points in Desert, Dryland, Wet tropical and Wet tropical forest Recharge Landscapes, respectively. Recharge Landscapes which have high annual recharge rates also have higher recharge ratios suggesting that as well as being generally wetter, they are more efficient in converting that rainfall into recharge (Figure 6). We also investigated the possible influence of the different groundwater recharge estimation methods to see whether this explained any of the variability in annual recharge and recharge ratio estimates within the individual spatial units (see supplemental information). However, in agreement with (MacDonald et al. 2021) we did not find a relationship between the 
504
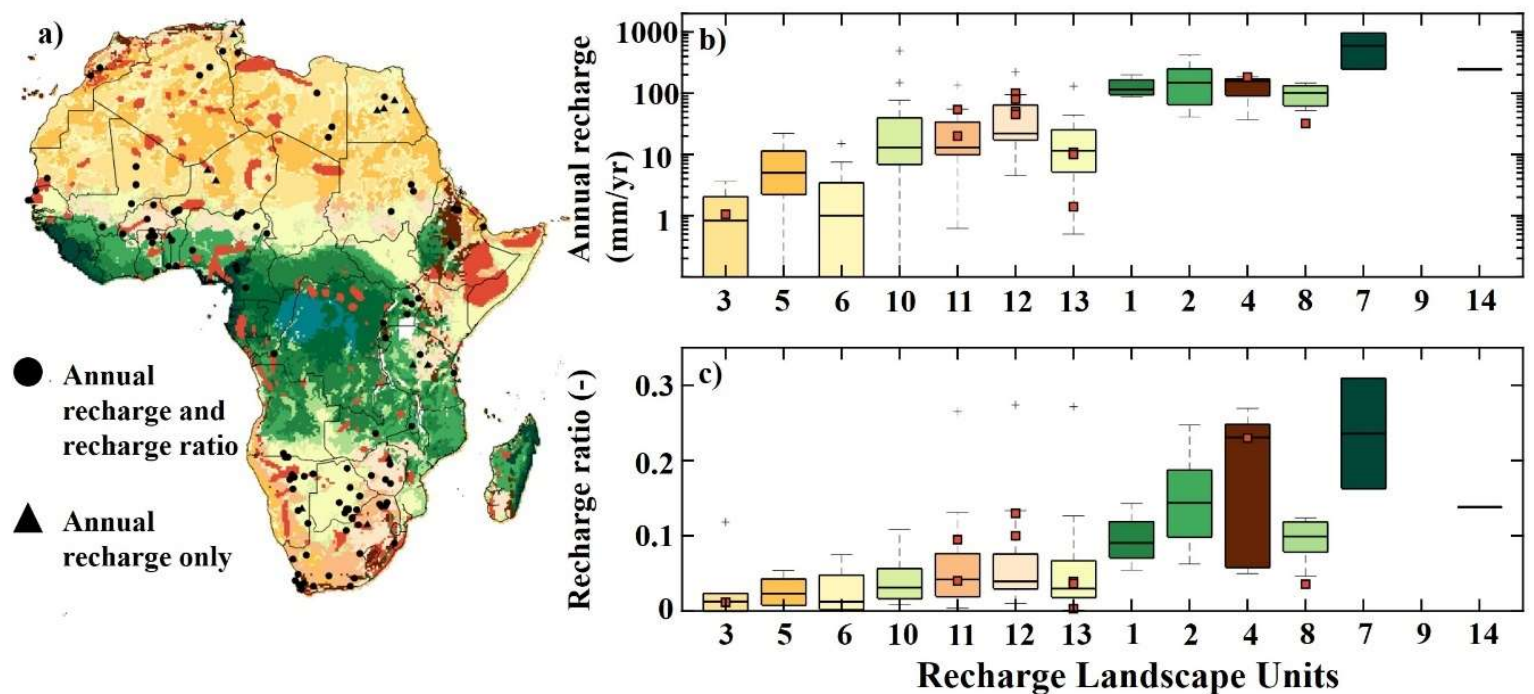

Figure 6. a) Map of ground-based estimate data points distributed across the Classification of recharge controls in Africa. Boxplots of the ground-based estimates of long-term mean annual recharge (b) and recharge ratio (c) found in each of the Recharge Landscape Units. No data points are located within Unit 9 and hence it is not shown. Only one data point is located within Unit 14. Unit 15 representing karst does not have its own boxplot. Instead, we have superimposed (red dots) these data points above the units which they would have otherwise been attributed to.

Desert $(R L U$ 3, 5, 6)

Desert Recharge Landscapes are characterised by low moisture availability (P-PET), low vegetation cover (kveg) and very high sand content in its soils (Figure 5). These properties lead to the lowest annual recharge and recharge ratio estimates occurring in Africa, as $80 \%$ of annual recharge (recharge ratio) estimates in Desert Recharge Landscapes are below $5 \mathrm{~mm} /$ year (4\%). Low recharge ratios in these units suggest that even when rain does fall, much of the water stored in the sandy soils is subsequently evaporated with very little deeper drainage occurring. We also find ground-based recharge estimates in Desert Recharge Landscapes show very little variability. Although we find marginally greater annual recharge rates and recharge ratios in unit 5, we cannot explain why, and differences may not be significant as there are only 20 data points across this region. 
522 About $51 \%$ of the 129 ground-based estimates are sited in Dryland Recharge Landscapes

523 where water is generally only available for recharge seasonally (units 10,11, 12 and 13). 70\%

524 of these sites have annual recharge rates between $3-30 \mathrm{~mm} /$ year and a further $18 \%$ of these

525 sites have rates between $30-100 \mathrm{~mm} /$ year. Typically, in these regions less than $10 \%$ of

526 rainfall is converted to recharge, with only 9 of the 58 sites recording higher recharge ratios.

527 In this Recharge Landscape, we find that long-term estimates of annual recharge vary

528 according to mean annual precipitation, whereas recharge ratios are greater at sites with

529 greater monthly variability in P-PET (Figure 7).
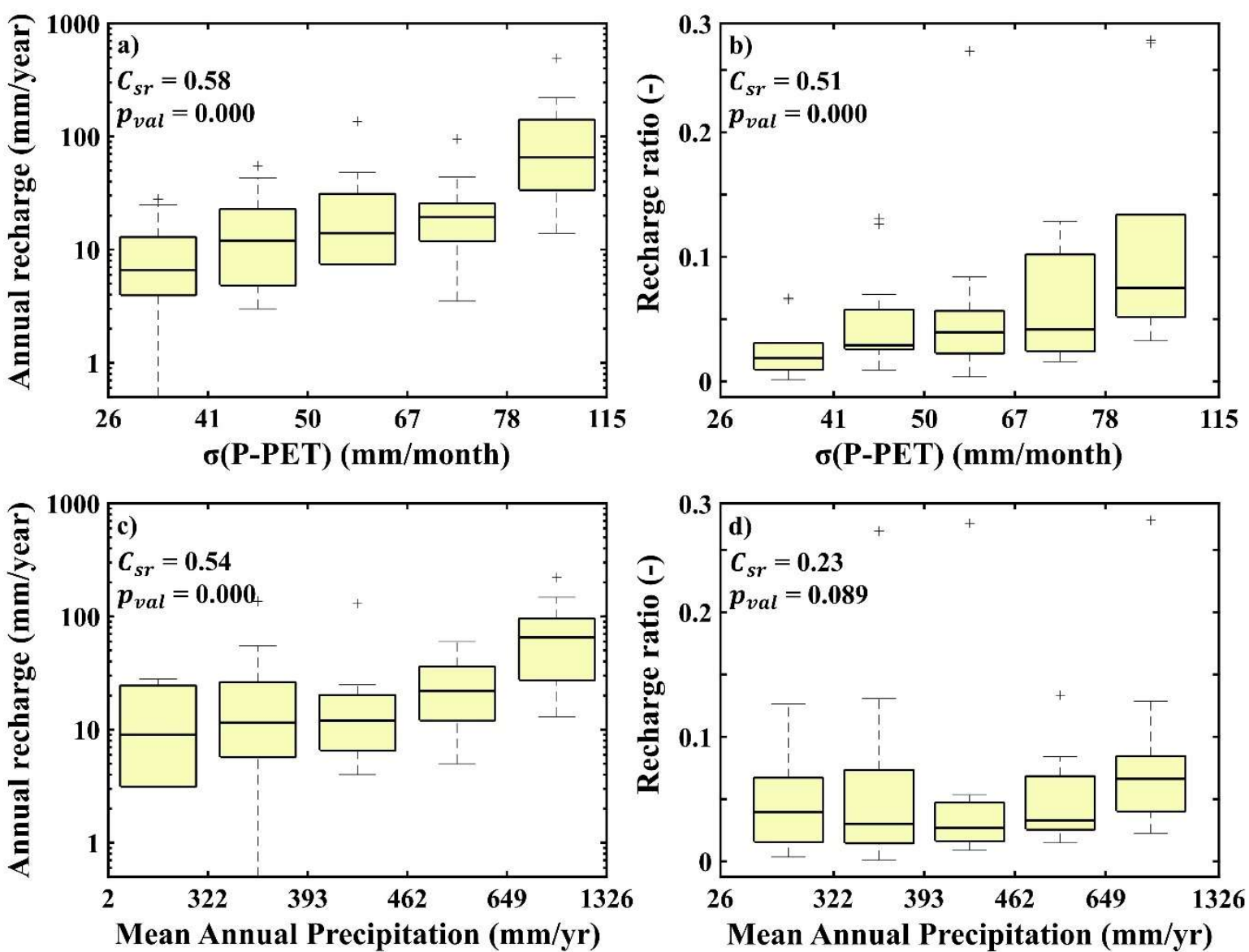

Figure 7. Boxplots showing how ground-based estimates of mean annual recharge (a, c) and recharge ratio (b, d) vary according to monthly variability of P-PET and Mean Annual Precipitation in Dryland Recharge Landscapes. Recharge signatures are binned according to percentiles $(0-20 ; 20-40 ; 40-60 ; 60-80 ; 80-100)$ of the controlling variable. In the top left corner of each sub-plot, we show the spearman rank correlation and the p-value for testing the hypothesis of no correlation.

Wet tropical $(1,2,4,8)$ 

exceed $100 \mathrm{~mm} /$ year $(50 \mathrm{~mm} /$ year $)$. These sites are also the more efficient in converting rainfall to recharge with $56 \%(92 \%)$ of them having recharge ratios greater than $10 \%(5 \%)$.

The wetter as well as seasonal periods of heavy monsoon rain allows deeper drainage, despite

540 increased partitioning of rainfall at the land surface by vegetation, steeper terrain, and less permeable soils. Most of the variability between and within Wet tropical landscape units is attributed to differences in annual and seasonal scale water excess (P-PET) and heavy rainfall events (P10).

Differences in annual recharge and recharge ratio estimates of units 1 (median annual recharge $115 \mathrm{~mm} /$ year; median recharge ratio $9 \%$ ) and 2 (median annual recharge $148 \mathrm{~mm} /$ year; median recharge ratio 14\%) could be attributed to greater LAI and Kveg properties in unit 2. However, when comparing the properties of the individual sites we do not find this relationship. Highland areas (unit 4) show a particularly large variability in the fraction of precipitation being converted to recharge. This perhaps reflects the high degree of variability we can expect in highland regions depending upon landscape positioning.

These areas are characterised by the highest vegetation cover (LAI) and moisture availability (P-PET). We only have three ground-based estimates of annual recharge and recharge ration within this Recharge Landscape: 2 two in unit 7 and one in 14. The highest annual recharge estimate in our database is located in unit 7 , with $31 \%$ of rainfall being converted to recharge to allow a rate of $941 \mathrm{~mm} / \mathrm{yr}$. Referring to existing literature, we find that in addition to high annual precipitation rates $(3050 \mathrm{~mm} / \mathrm{yr})$ extensive bedrock fracturing near the land surface enables rapid infiltration and recharge (Kamtchueng et al. 2015). 
We do not find a clear pattern whereby the presence of karst at a site indicates higher annual recharge rates or recharge ratios than other sites within a similar setting (Figure 6). When investigating the individual studies, which according to our global dataset are located in karst geology, some studies did not report the presence of karst. Highlighting, the limitations of global datasets when investigating ground-based and regional recharge processes. Within settings defined as karst by global datasets, annual recharge rates and recharge ratios increase with increasing annual scale P-PET (see supplemental information).

\section{Discussion}

\subsection{Which regions of Africa show similar recharge controls when clustered} using descriptors derived from global datasets?

We find 15 Recharge Landscape Units within which we expect recharge processes to be similar, according to our clustering result. Only 9 Recharge Landscape Units are needed to characterize over $80 \%$ of the continent's land area. We have further aggregated our 14 (out of 15) Recharge Landscape Units into four Recharge Landscapes, largely according to climate.

These Recharge Landscapes are Desert, Dryland, Wet tropical and Wet tropical forest, which account for $32.5 \%, 26.9 \%, 24.6 \%$ and $8.4 \%$ of Africa's land area respectively (total of 92.4 ). An additional $7.25 \%$ of the continent's land area is defined by its geology (i.e. karst) and can be found distributed across each of the four previously mentioned Recharge Landscapes (as we would expect according to previous studies, e.g. Hartmann et al., 2017). At the resolution of our classification, climate indices have strong positive correlations with landcover indices (pearson correlation coefficient $>0.7$ ). It is not surprising that our Recharge Landscapes strongly resemble previous climate classifications (Peel et al., 2007; Knoben et al., 2018), because climate is a dominant control on the long-term evolution of land surface and near 
surface landscape characteristics including topography (Chen et al. 2019), soils and vegetation (Pelletier et al. 2013).

Our Recharge Landscapes broadly resembles the ecozones in classifications by Olson et al. (2001) and Jasechko et al. (2014), which identify five and three different regions across Africa respectively. They are also similar to the five regions delineated by MacDonald et al. (2021) when using aridity classes to investigate the spatial variability of recharge across Africa. Unlike Olson et al. (2001) and Jasechko et al. (2014) we do not aggregate deserts and xeric shrublands, which we instead include in our Dryland Recharge Landscapes. Hence our Desert Recharge Landscapes more closely align with the hyper-arid regions delineated by MacDonald et al. (2021), whilst our Dryland Recharge Landscapes also align with their arid and semi-arid regions. By separating dry systems according to the occurrence of vegetation, we differentiate between regions where transpiration has a greater effect on recharge processes (Scott et al., 2006; Cavanaugh et al., 2011; Gebreyohannes et al., 2013).

Consequently, we organise the Kalahari Desert as a Dryland, as it is affected by transpiration (Foster et al. 1982). Our Dryland Recharge Landscapes can be found throughout the desert, shrubland and tropical biomes of classifications by Olson et al. (2001) and Jasechko et al. (2014). Thus, previous ecozone classifications may have delineated these regions too broadly. We also see that by identifying Dryland Recharge Landscapes with low slope and high bedrock depths (RLU 13), we identified a landscape unit where large seasonal wetlands are likely to occur (Olson et al. 2001). These wetlands include the Okavango delta, the Kafue and Barotse floodplains in Southern Africa; the Sudd Swamps in Eastern Africa; and the inland Niger delta, Hadejia-Nguru wetlands and wetlands of Southern Chad in the Sahel. Such wetlands can be significant sources of annually occurring focused groundwater recharge,

607 given soil conditions do not restrict infiltration (Edmunds et al., 1999; Wolski et al., 2006). 
609 (2021), we further disaggregate Desert Recharge Landscapes according to depth to bedrock.

610 In Desert Recharge Landscapes, shallow bedrock depths largely align with mountainous

611 regions, which are often regarded as important recharge zones for current episodic recharge

612 events (Gheith and Sultan 2002; Sultan et al. 2007) and more regular recharge events in

613 previous paleoclimate periods (Sturchio et al. 2004). Our Wet tropical forest Recharge

614 Landscapes largely align with the tropical and subtropical moist forests shown in Olson et al.

615 (2001). Though further disaggregation into units identifies unique regions such as the Swamp

616 forests of the Congo Basin and regions with extreme monsoonal rainfall in the Gulf of

617 Guinea. In contrast, neither Jasechko et al. (2014) nor MacDonald et al. (2021) identify the

618 forested regions of their tropical and humid classes, respectively.

619

620

5.2 How do regions with similar controls compare to ground-based recharge estimates?

622

623

624

625

626

627

In Africa, Recharge Landscapes with greater long-term mean annual recharge rates are also more efficient in converting precipitation to recharge, as shown by the higher long-term mean recharge ratio estimates. We do not know whether this relationship is found across other continents or regions as previous studies investigating the controls on ground-based recharge estimates across large spatial scales assess the spatial variability of annual recharge rates only (Moon et al., 2004; Mohan et al., 2018; Moeck et al., 2020; MacDonald et al., 2021). Investigating how recharge signatures interact in space allowed us to advance our conceptualisations of recharge processes across Africa. Though comparative hydrology is only just starting to be recognised by observational investigations within the groundwater community (Haaf et al. 2020; Heudorfer et al. 2019), it is well established within the surface water community (Addor et al. 2018; Sawicz et al. 2011, 2014) and has already been used in 
633 global scale groundwater investigations using global scale modelling products (Cuthbert et 634 al., 2019a).

635 Even though we can explain the variability of ground-based estimates of annual recharge and recharge ratio between different Recharge Landscapes, we have very limited ability to explain why they vary within Recharge Landscapes using global datasets. Wet tropical and Wet tropical forest Recharge Landscapes receive higher rates of annual recharge and are also more efficient in converting precipitation to recharge than Dryland and Desert Recharge Landscapes, as shown by the higher recharge ratio estimates in these places. This is not surprising, as heavy seasonal, monthly and daily rainfall is already known to be important for recharge processes in both tropical and dry regions of Africa (Döll and Fiedler 2008; Jasechko and Taylor 2015; Owor et al. 2009; Taylor et al. 2013). Furthermore, in agreement with Taylor et al. (2013), we find that mean annual recharge ratios in Dryland Recharge Landscapes, increase with monthly variability in P-PET. However, interactions with other large-scale physical or biological indices offer little further explanation for why ground-based estimates of annual recharge and recharge ratio vary within individual Recharge Landscapes. For the most part, our inability to explain the spatial variability of ground-based recharge estimates within Recharge Landscapes stresses the limitations of global datasets for describing the complex interactions between landscape properties and how they control more local recharge processes. Previous studies trying explain the spatial variability of recharge processes at continental and global scales also mostly establish relationships with broad climate and eco-hydrological patterns (Jasechko et al., 2014; Cuthbert et al., 2019b; MacDonald et al., 2021). Furthermore, MacDonald et al. (2021) found that there are spatial correlations in long-term average recharge rates across Africa up to distances of $900 \mathrm{~km}$, which cannot yet be explained by environmental properties. Ultimately, this suggests a gap 
between what we can learn from local insight and from large scale regionalization, regarding the interaction of environmental properties and their control over recharge processes.

659

$660 \quad 5.3$ Looking ahead

661 Given the limited explanatory power of global datasets as shown in our and other previous

662 studies, it is likely that continental and global scale modelling of groundwater recharge can benefit from the implementation of landscape-based conceptualisations of recharge processes and controls (Gao et al. 2018). Hartmann et al. (2015) showed (for carbonate rock regions across Europe and Northern Africa) that even relatively simple process conceptualizations capture main differences in recharge dynamics between different large landscape groups.

Such conceptual models characterize largely our prior understanding of groundwater recharge in different landscapes. This is likely to be particularly important in data sparse regions where

669 we cannot reasonably rely upon model parameterisation schemes that rely heavily on the reliability of soils and other data (Wagener et al. 2021). Adding information through the definition of simple system conceptualizations, would enable us to further combine expected hydrologic behaviour of the landscape with widely available datasets (e.g. Cuthbert et al., 2019b). By focussing on regionally dominant recharge controls, we can develop more parsimonious mathematical models that are also more appropriate for the data scarcity found

675 in many places (Sarrazin et al., 2018), or specific hydrologic processes of most relevance 676 (Quichimbo et al. 2021). 

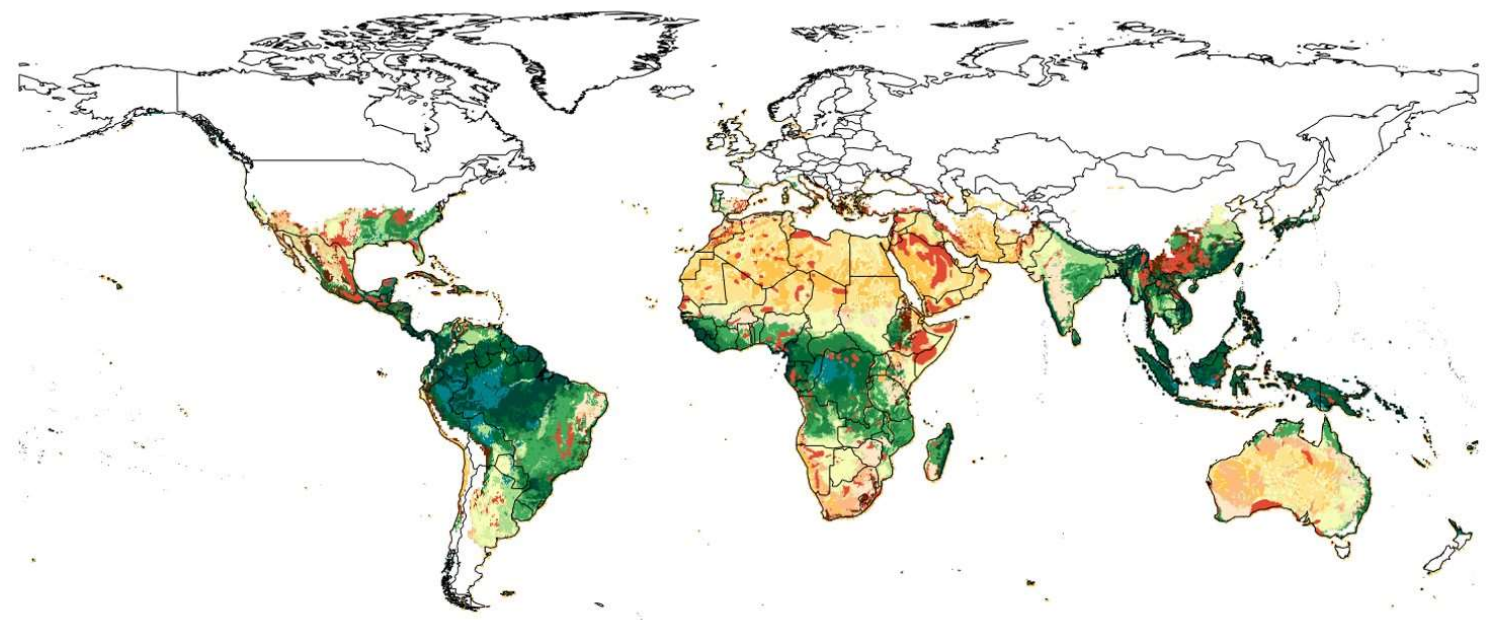

Figure 8. Application of the recharge landscape classification framework to domains outside of the study region. We used a random forest to transfer our Recharge Landscape Units across the rest of the world, with the previously discussed recharge control indices acting as predictor variables. The random forest model is an ensemble of 25 classification trees each with a maximum of 400 decision splits. The model was trained on data points in Africa which were randomly selected with replacement from a sub-sample of 70\% of the Africa data points ('in-bag'). Model testing on 'out of bag' data points found a misclassification rate of just $4 \%$. Areas shown in white are significantly dissimilar to the study region. The criterion for this separation was having mean temperatures below $13.5^{\circ} \mathrm{C}$ or above $35.5^{\circ} \mathrm{C}$ and snow fractions above 0.1 . We estimated snow fractions by using a simple temperature threshold. Precipitation on days with an average temperature below $1^{\circ} \mathrm{C}$ is regarded as entirely snowfall whereas it is entirely rainfall on days with an average temperature above $1^{\circ} \mathrm{C}$ (Berghuijs et al., 2014). We use a global gridded dataset of daily temperature provided by the Climate Prediction Center, NOAA (NOAA/OAR/ESRL PSD). Further details are provided in the supplemental information.

The value of comparative hydrology in this context could lie in identifying regions of similarity beyond the direct study domain. As discussed here, specific studies with groundbased estimates of groundwater recharge are rare - certainly across Africa. Figure 8 shows how the classification approach introduced here would classify other regions of the world if applied globally. All areas shown in white are significantly dissimilar to our study domain and hence unsuitable for comparison. However, areas in colour map onto some areas in our domain and thus offer the potential for transferability of knowledge gained from outside our direct study domain. For example, studies in karst regions (shown in red) might complement the rather sparse ground-based measurements available inside Africa, thus offering an opportunity to expand on existing datasets like that compiled by MacDonald et al. (2021).

\section{Conclusions}


We set out to study the variability of groundwater recharge across Africa through the use of a classification of groundwater recharge controls as landscape elements, utilising global datasets to characterize our a priori understanding following an extensive literature review. Our final classification consists of 15 recharge landscape units which are similar across the 11 indices we used to describe recharge controls across the continent. We aggregated these Recharge Landscape Units into four larger Recharge Landscapes, including Desert, Dryland, Wet tropical, and Wet tropical forest, which broadly agrees with classifications by Olson et al. (2001) and Jasechko et al. (2014). Karstic environments are treated separately, scattered across each of the Recharge Landscapes we have found.

A classification approach has allowed us to consolidate most of the findings from previous studies into a spatial representation of expected recharge controls across the African continent. Much of our previous understanding of recharge processes in Africa was point or plot based, originating from the case studies which have assessed recharge processes and controls throughout the region. We hypothesize that the small number of Recharge Landscapes needed to characterize the broader recharge controls of the African landscape, is explained by the dominance of climatic controls, likely connected with the co-evolution of vegetation, soils, and topography. These Recharge Landscapes were useful in organising ground-based estimates of annual recharge and recharge ratio. Yet, in exception of Dryland Recharge Landscapes, we were not able explain the variability of estimated recharge signatures within each of the Recharge Landscapes using global datasets alone.

This result highlights the limits of using global datasets to decipher the complex interactions of landscape properties in controlling recharge processes. Nonetheless, future data-based modelling of groundwater recharge at continental scales could be advanced by using methods which explore the relationships between controls and recharge within regions of similarity, instead of across the entire continent (MacDonald et al. 2021). Further advancement is also 
likely to come from the development of system conceptualizations which allow us to add more information than that embedded in global datasets (Wagener et al. 2021). This would lead to a convergence of top-down strategies (such as classification) with other more bottomup approaches like the one taken by Cuthbert et al. (2019b). Further expanding the study domain using similarity principles might offer a strategy for expanding existing strategies. Furthermore, considering the co-evolution of multiple landscape properties could help further separate the hydrologically relevant behaviour of different places (Troch et al. 2013), which in turn could help the predictive ability of global datasets used in model parameterisations. Currently such expected hydrologic behaviour (derived from literature reviews), is only considered through the definition of appropriate predictor variables.

Finally, as meta-analysis databases become more common in continental and global scale hydrological studies (Moeck et al. 2020; Wang et al. 2020), we would like to stress the importance of thorough quality assurance in their initial development. Our findings from these studies depend upon strong underlying datasets and it is unlikely future studies will assess the quality of these datasets when investigating or expanding upon them. For the same reasons, the initial development of these databases should also ensure that additional metainformation is comprehensive.

\section{Acknowledgements}

$\mathrm{CW}$ is funded as part of the WISE CDT under a grant from the Engineering and Physical Sciences Research Council (EPSRC), grant EP/L016214/1. MOC gratefully acknowledges funding for an Independent Research Fellowship from the UK Natural Environment Research Council (NE/P017819/1). 


\section{References}

Abdalla, Osman A. E. 2009. "Groundwater Recharge/discharge in Semi-Arid Regions Interpreted from Isotope and Chloride Concentrations in North White Nile Rift, Sudan.” Hydrogeology Journal 17(3):679-92.

Abdullateef, Lawal, Moshood N. Tijani, Nabage A. Nuru, Shirputda John, and Aliyu Mustapha. 2021. "Assessment of Groundwater Recharge Potential in a Typical Geological Transition Zone in Bauchi, NE-Nigeria Using Remote sensing/GIS and MCDA Approaches.” Heliyon 7(4):e06762.

Abidela Hussein, Misbah, Habtamu Muche, Petra Schmitter, Prossie Nakawuka, Seifu A. Tilahun, Simon Langan, Jennie Barron, and Tammo S. Steenhuis. 2019. “Deep Tillage Improves Degraded Soils in the (Sub) Humid Ethiopian Highlands." Land 8(11):159.

Abotalib, Abotalib Z., Mohamed Sultan, and Racha Elkadiri. 2016. “Groundwater Processes in Saharan Africa: Implications for Landscape Evolution in Arid Environments.” Earth-Science Reviews 156:108-36.

Abu-Hamdeh, N. H. 2004. "The Effect of Tillage Treatments on Soil Water Holding Capacity and on Soil Physical Properties." 13th International Soil Conservation Organisation Conference (669):1-6.

Acosta, Verónica Torres, Taylor F. Schildgen, Brian A. Clarke, Dirk Scherler, Bodo Bookhagen, Hella Wittmann, Friedhelm Von Blanckenburg, and Manfred R. Strecker. 2015. "Effect of Vegetation Cover on Millennial-Scale Landscape Denudation Rates in East Africa." Lithosphere 7(4):408-20.

Adams, S., R. Titus, and Y. Xu. 2004. Groundwater Recharge Assessment of the Basement Aquifers of Central Namaqualand. Vol. No. 1093/1.

Addor, N., G. Nearing, C. Prieto, A. J. Newman, N. Le Vine, and M. P. Clark. 2018. "A Ranking of Hydrological Signatures Based on Their Predictability in Space.” Water Resources Research, 8792-8812. 
Attandoh, Nelson, Sandow Mark Yidana, Aliou Abdul-Samed, Patrick Asamoah Sakyi, Bruce Banoeng-Yakubo, and Prosper M. Nude. 2013. "Conceptualization of the Hydrogeological System of Some Sedimentary Aquifers in Savelugu-Nanton and Surrounding Areas, Northern Ghana." Hydrological Processes 27(11):1664-76.

Ayadi, Yosra, Naziha Mokadem, Houda Besser, Faten Khelifi, Samia Harabi, Amor Hamad, Adrian Boyce, Rabah Laouar, and Younes Hamed. 2018. "Hydrochemistry and Stable Isotopes ( $\delta 180$ and $\delta 2 \mathrm{H}$ ) Tools Applied to the Study of Karst Aquifers in Southern Mediterranean Basin (Teboursouk Area, NW Tunisia)." Journal of African Earth Sciences 137:208-17.

Azagegn, Tilahun, Asfawossen Asrat, Tenalem Ayenew, and Seifu Kebede. 2015. "Litho-Structural Control on Interbasin Groundwater Transfer in Central Ethiopia." Journal of African Earth Sciences 101:383-95.

Banks, Eddie W., Peter G. Cook, Michael Owor, Joseph Okullo, Seifu Kebede, Dessie Nedaw, Prince Mleta, Helen Fallas, Daren Gooddy, Donald John MacAllister, Theresa Mkandawire, Patrick Makuluni, Chikondi E. Shaba, and Alan M. MacDonald. 2021. "Environmental Tracers to Evaluate Groundwater Residence Times and Water Quality Risk in Shallow Unconfined Aquifers in Sub Saharan Africa.” Journal of Hydrology 598.

Barbeta, Adrià and Josep Peñuelas. 2017. "Relative Contribution of Groundwater to Plant Transpiration Estimated with Stable Isotopes.” Scientific Reports 7(1):1-10.

Beck, Hylke E., Albert I. J. M. Van Dijk, Vincenzo Levizzani, Jaap Schellekens, Diego G. Miralles, Brecht Martens, and Ad De Roo. 2017. "MSWEP: 3-Hourly $0.25^{\circ}$ Global Gridded Precipitation (1979-2015) by Merging Gauge, Satellite, and Reanalysis Data.” Hydrology and Earth System Sciences 21(1):589-615.

Befus, Kevin M., Scott Jasechko, Elco Luijendijk, Tom Gleeson, and M. Bayani Cardenas. 2017. “The Rapid yet Uneven Turnover of Earth's Groundwater.” Geophysical Research Letters 44(11):5511-20. 
Benito, Gerardo, Rick Rohde, Mary Seely, Christoph Külls, Ofer Dahan, Yehouda Enzel, Simon Todd, Blanca Botero, Efrat Morin, Tamir Grodek, and Carole Roberts. 2010. "Management of Alluvial Aquifers in Two Southern African Ephemeral Rivers: Implications for IWRM.” Water Resources Management 24(4):641-67.

Berghuijs, W. R., R. A. Woods, and M. Hrachowitz. 2014. “A Precipitation Shift from Snow towards Rain Leads to a Decrease in Streamflow." Nature Climate Change 4(7):583-86.

Beven, Keith and Peter Germann. 1982. "Macropores and Water Flow in Soils." Water Resources Research 18(5):1311-25.

Bierkens, Marc F. P. 2015. “Global Hydrology 2015: State, Trends, and Directions.” Water Resources Research 51(7):4923-47.

Bonsor, H. C., A. M. Macdonald, and J. Davies. 2014. "Evidence for Extreme Variations in the Permeability of Laterite from a Detailed Analysis of Well Behaviour in Nigeria." Hydrological Processes 28(10):3563-73.

Boufekane, Abdelmadjid, Hind Meddi, and Mohamed Meddi. 2020. "Delineation of Groundwater Recharge Zones in the Mitidja Plain, North Algeria, Using Multi-Criteria Analysis.” Journal of Hydroinformatics 22(6):1468-84.

Bouimouass, Houssne, Younes Fakir, Sarah Tweed, and Marc Leblanc. 2020. “Groundwater Recharge Sources in Semiarid Irrigated Mountain Fronts.” Hydrological Processes 34(7):15981615.

Bouvet, Alexandre, Stéphane Mermoz, Thuy Le Toan, Ludovic Villard, Renaud Mathieu, Laven Naidoo, and Gregory P. Asner. 2018. “An above-Ground Biomass Map of African Savannahs and Woodlands at 25 M Resolution Derived from ALOS PALSAR.” Remote Sensing of Environment 206:156-73.

Breiman, L. 2001. "Random Forests.” Machine Learning 45:5-32.

Breiman, L., J. H. Friedman, R. A. Olshen, and C. J. Stone. 1984. Classification and Regression 
Bromley, J., W. M. Edmunds, E. Fellman, J. Brouwer, S. R. Gaze, J. Sudlow, and J. D. Taupin. 1997. "Estimation of Rainfall Inputs and Direct Recharge to the Deep Unsaturated Zone of Southern Niger Using the Chloride Profile Method." Journal of Hydrology 188-189(1-4):139-54.

Brown, Molly E., Kirsten de Beurs, and Anton Vrieling. 2010. “The Response of African Land Surface Phenology to Large Scale Climate Oscillations." Remote Sensing of Environment 114(10):2286-96.

Brunner, Philip, Peter Bauer, Martin Eugster, and Wolfgang Kinzelbach. 2004. "Using Remote Sensing to Regionalize Local Precipitation Recharge Rates Obtained from the Chloride Method." Journal of Hydrology 294(4):241-50.

Burke, Antje. 2003. "Inselbergs in a Changing World - Global Trends." Diversity and Distributions 9(5):375-83.

Butterworth, J. A., D. M. J. Macdonald, J. Bromley, L. P. Simmonds, C. J. Lovell, and F. Mugabe. 1999. "Hydrological Processes and Water Resources Management in a Dryland Environment III: Groundwater Recharge and Recession in a Shallow Weathered Aquifer." Hydrology and Earth System Sciences 3(3):345-51.

Calow, R. C., N. S. Robins, A. M. Macdonald, D. M. J. Macdonald, B. R. Gibbs, W. R. G. Orpen, P. Mtembezeka, A. J. Andrews, and S. O. Appiah. 1997. "Groundwater Management in DroughtProne Areas of Africa." International Journal of Water Resources Development 13(2):241-61.

Cavanaugh, Michelle L., Shirley A. Kurc, and Russell L. Scott. 2011. "Evapotranspiration Partitioning in Semiarid Shrubland Ecosystems: A Two-Site Evaluation of Soil Moisture Control on Transpiration.” Ecohydrology 4(5):671-81.

Chemseddine, Fehdi, Belfar Dalila, and Baali Fethi. 2015. "Characterization of the Main Karst Aquifers of the Tezbent Plateau, Tebessa Region, Northeast of Algeria, Based on Hydrogeochemical and Isotopic Data.” Environmental Earth Sciences 74(1):241-50. 
Chen, Shiuan An, Katerina Michaelides, Stuart W. D. Grieve, and Michael Bliss Singer. 2019. “Aridity Is Expressed in River Topography Globally.” Nature 573(7775):573-77.

Conway, Declan, Aurelie Pereschino, Sandra Ardoin-Bardin, Hamisai Hamandawana, Claudin Dieulin, and Gil Mahé. 2009. "Rainfall and Water Resources Variability in Sub-Saharan Africa during the Twentieth Century." Journal of Hydrometeorology 10(1):41-59.

Cuthbert, M. O., T. Gleeson, N. Moosdorf, K. M. Befus, A. Schneider, J. Hartmann, and B. Lehner. 2019. "Global Patterns and Dynamics of Climate-groundwater Interactions.” Nature Climate Change 9(2):137-41.

Cuthbert, M. O. and C. Tindimugaya. 2010. "The Importance of Preferential Flow in Controlling Groundwater Recharge in Tropical Africa and Implications for Modelling the Impact of Climate Change on Groundwater Resources." Journal of Water and Climate Change 1(4):234-45.

Cuthbert, Mark O., Richard G. Taylor, Guillaume Favreau, Martin C. Todd, Mohammad Shamsudduha, Karen G. Villholth, Alan M. MacDonald, Bridget R. Scanlon, D. O.Valerie Kotchoni, Jean-Michel Vouillamoz, Fabrice M. A. Lawson, Philippe Armand Adjomayi, Japhet Kashaigili, David Seddon, James P. R. Sorensen, Girma Yimer Ebrahim, Michael Owor, Philip M. Nyenje, Yahaya Nazoumou, Ibrahim Goni, Boukari Issoufou Ousmane, Tenant Sibanda, Matthew J. Ascott, David M. J. Macdonald, William Agyekum, Youssouf Koussoubé, Heike Wanke, Hyungjun Kim, Yoshihide Wada, Min-Hui Lo, Taikan Oki, and Neno Kukuric. 2019. "Observed Controls on Resilience of Groundwater to Climate Variability in Sub-Saharan Africa." Nature 572(7768):230-34.

Dabous, A. A. and J. K. Osmond. 2001. "Uranium Isotopic Study of Artesian and Pluvial Contributions to the Nubian Aquifer, Western Desert, Egypt.” Journal of Hydrology 243(34):242-53.

Defourny, P., S. Bontemps, C. Lamarche, C. Brockmann, M. Boettcher, J. Wevers, G. Kirches, and M. Santoro. 2017. “Land Cover CCI Product User Guide - Version 2.0.” ESA 1-105. 
Demlie, Molla. 2015. “Assessment and Estimation of Groundwater Recharge for a Catchment Located in Highland Tropical Climate in Central Ethiopia Using Catchment Soil-water Balance (SWB) and Chloride Mass Balance (CMB) Techniques." Environmental Earth Sciences 74(2):1137-50.

Demlie, Molla, Stefan Wohnlich, Birhanu Gizaw, and Willibald Stichler. 2007. “Groundwater Recharge in the Akaki Catchment, Central Ethiopia: Evidence from Environmental Isotopes ( $\delta 18 \mathrm{O}, \delta 2 \mathrm{H}$ and3H) and Chloride Mass Balance." Hydrological Processes 21(6):807-18.

Descheemaeker, Katrien, Jan Nyssen, Jean Poesen, Dirk Raes, Mitiku Haile, Bart Muys, and Seppe Deckers. 2006. "Runoff on Slopes with Restoring Vegetation: A Case Study from the Tigray Highlands, Ethiopia.” Journal of Hydrology 331(1-2):219-41.

Descroix, L., G. Mahé, T. Lebel, G. Favreau, S. Galle, E. Gautier, J. C. Olivry, J. Albergel, O. Amogu, B. Cappelaere, R. Dessouassi, A. Diedhiou, E. Le Breton, I. Mamadou, and D. Sighomnou. 2009. "Spatio-Temporal Variability of Hydrological Regimes around the Boundaries between Sahelian and Sudanian Areas of West Africa: A Synthesis.” Journal of Hydrology 375(1-2):90-102.

Dettinger, Michael D. and Henry F. Diaz. 2000. “Global Characteristics of Stream Flow Seasonality and Variability." Journal of Hydrometeorology 1(4):289-310.

Dietrich, William E. and J.Taylor Perron. 2006. "The Search for a Topographic Signature of Life.” Nature 439(7075):411-18.

Diouf, Coly. 2012. "Combined Uses of Water-Table Fluctuation (WTF), Chloride Mass Balance (CMB) and Environmental Isotopes Methods to Investigate Groundwater Recharge in the Thiaroye Sandy Aquifer (Dakar, Senegal).” African Journal of Environmental Science and Technology 6(11):425-37.

Döll, P. and K. Fiedler. 2008. "Global-Scale Modeling of Groundwater Recharge.” Hydrology and Earth System Sciences 12(3):863-85. 
Dormann, Carsten F., Jane Elith, Sven Bacher, Carsten Buchmann, Gudrun Carl, Gabriel Carré, Jaime R.Garcí. Marquéz, Bernd Gruber, Bruno Lafourcade, Pedro J. Leitão, Tamara Münkemüller, Colin Mcclean, Patrick E. Osborne, Björn Reineking, Boris Schröder, Andrew K. Skidmore, Damaris Zurell, and Sven Lautenbach. 2013. "Collinearity: A Review of Methods to Deal with It and a Simulation Study Evaluating Their Performance.” Ecography 36(1):027-046.

Edmunds, W. M., W. G. Darling, D. G. Kinniburgh, S. Kotoub, and S. Mahgoub. 1992. "Sources of Recharge at Abu Delaig, Sudan.” Journal of Hydrology 131(1-4):1-24.

Edmunds, W. M., E. Fellman, and I. B. Goni. 1999. "Lakes, Groundwater and Palaeohydrology in the Sahel of NE Nigeria: Evidence from Hydrogeochemistry." Journal of the Geological Society 156(2):345-55.

Edmunds, W. M. and C. B. Gaye. 1994. "Estimating the Spatial Variability of Groundwater Recharge in the Sahel Using Chloride." Journal of Hydrology 156(1-4):47-59.

Egli, Markus and Jérôme Poulenard. 2016. "Soils of Mountainous Landscapes." Pp. 1-10 in International Encyclopedia of Geography: People, the Earth, Environment and Technology.

Farid, Intissar, Kamel Zouari, Rim Trabelsi, and Abd Rahmen Kallali. 2014. “Application of Environmental Tracers to Study Groundwater Recharge in a Semi-Arid Area of Central Tunisia.” Hydrological Sciences Journal 59(11):2072-85.

Fashae, Olutoyin A., Moshood N. Tijani, Abel O. Talabi, and Oluwatola I. Adedeji. 2014. "Delineation of Groundwater Potential Zones in the Crystalline Basement Terrain of SWNigeria: An Integrated GIS and Remote Sensing Approach.” Applied Water Science 4(1):19-38.

Favreau, G., B. Cappelaere, S. Massuel, M. Leblanc, M. Boucher, N. Boulain, and C. Leduc. 2009. "Land Clearing, Climate Variability, and Water Resources Increase in Semiarid Southwest Niger: A Review." Water Resources Research 45(7):W00A16.

Foster, S. S. D., A. H. Bath, J. L. Farr, and W. J. Lewis. 1982. "The Likelihood of Active Groundwater Recharge in the Botswana Kalahari.” Journal of Hydrology 55(1-4):113-36. 
Foster, S. S. D., B. L. Morris, and P. J. Chilton. 1999. “Groundwater in Urban Development-a Review of Linkages and Concerns.” IAHS-AISH Publication (259):3-12.

Francis, M. L., M. V. Fey, H. P. Prinsloo, F. Ellis, A. J. Mills, and T. V. Medinski. 2007. “Soils of Namaqualand: Compensations for Aridity.” Journal of Arid Environments 70(4):588-603.

Gao, Hongkai, John L. Sabo, Xiaohong Chen, Zhiyong Liu, Zongji Yang, Ze Ren, and Min Liu. 2018. "Landscape Heterogeneity and Hydrological Processes: A Review of Landscape-Based Hydrological Models.” Landscape Ecology 33(9):1461-80.

Gebreyohannes, Tesfamichael, Florimond De Smedt, Kristine Walraevens, Solomon Gebresilassie, Abdelwasie Hussien, Miruts Hagos, Kasa Amare, Jozef Deckers, and Kindeya Gebrehiwot. 2013. “Application of a Spatially Distributed Water Balance Model for Assessing Surface Water and Groundwater Resources in the Geba Basin, Tigray, Ethiopia." Journal of Hydrology 499:110-23.

Gheith, Hazem and Mohamed Sultan. 2002. "Construction of a Hydrologic Model for Estimating Wadi Runoff and Groundwater Recharge in the Eastern Desert, Egypt.” Journal of Hydrology 263(1-4):36-55.

Good, Stephen P., David Noone, and Gabriel Bowen. 2015. "Hydrologic Connectivity Constrains Partitioning of Global Terrestrial Water Fluxes.” Science 349(6244):175-77.

Gordon, L. J., W. Steffen, B. F. Jonsson, C. Folke, M. Falkenmark, and A. Johannessen. 2005. "Human Modification of Global Water Vapor Flows from the Land Surface." Proceedings of the National Academy of Sciences 102(21):7612-17.

Gordon, Line J., Will Steffen, Bror F. Jönsson, Carl Folke, Malin Falkenmark, and Åse Johannessen. 2005. "Human Modification of Global Water Vapor Flows from the Land Surface." Proceedings of the National Academy of Sciences of the United States of America 102(21):7612-17.

Grodek, Tamir, Efrat Morin, David Helman, Itamar Lensky, Ofer Dahan, Mary Seely, Gerardo Benito, and Yehouda Enzel. 2020. "Eco-Hydrology and Geomorphology of the Largest Floods 
along the Hyperarid Kuiseb River, Namibia.” Journal of Hydrology 582(124450).

Guendouz, A., A. S. Moulla, B. Remini, and J. L. Michelot. 2006. "Hydrochemical and Isotopic Behaviour of a Saharan Phreatic Aquifer Suffering Severe Natural and Anthropic Constraints (Case of Oued-Souf Region, Algeria).” Hydrogeology Journal 14(6):955-68.

Haaf, Ezra, Markus Giese, Benedikt Heudorfer, Kerstin Stahl, and Roland Barthel. 2020. "Physiographic and Climatic Controls on Regional Groundwater Dynamics." Water Resources Research 56(10):1-20.

Hall, J. W., D. Grey, D. Garrick, F. Fung, C. Brown, S. J. Dadson, and C. W. Sadoff. 2014. “Coping with the Curse of Freshwater Variability." Science 346(6208):429-30.

Hamza, M. A. and W. K. Anderson. 2005. "Soil Compaction in Cropping Systems: A Review of the Nature, Causes and Possible Solutions.” Soil and Tillage Research 82(2):121-45.

Harris, Ian, Timothy J. Osborn, Phil Jones, and David Lister. 2020. "Version 4 of the CRU TS Monthly High-Resolution Gridded Multivariate Climate Dataset.” Scientific Data 7(1):1-18.

Hartmann, A., T. Gleeson, R. Rosolem, F. Pianosi, Y. Wada, and T. Wagener. 2015. “A Large-Scale Simulation Model to Assess Karstic Groundwater Recharge over Europe and the Mediterranean." Geoscientific Model Development 8(6):1729-46.

Hartmann, A., N. Goldscheider, T. Wagener, J. Lange, and M. Weiler. 2014. "Karst Water Resources in a Changing World: Review of Hydrological Modeling Approaches.” Reviews of Geophysics 52(3):218-42.

Hartmann, Andreas, Tom Gleeson, Yoshihide Wada, and Thorsten Wagener. 2017. "Enhanced Groundwater Recharge Rates and Altered Recharge Sensitivity to Climate Variability through Subsurface Heterogeneity.” Proceedings of the National Academy of Sciences 114(11):2842-47.

Hawinkel, P., W. Thiery, S. Lhermitte, E. Swinnen, B. Verbist, J. Van Orshoven, and B. Muys. 2016. "Vegetation Response to Precipitation Variability in East Africa Controlled by Biogeographical Factors.” Journal of Geophysical Research: Biogeosciences 121(9):2422-44. 
Healy, Richard W. 2010. Estimating Groundwater Recharge. Cambridge: Cambridge University Press.

Hengl, Tomislav, Jorge Mendes De Jesus, Gerard B. M. Heuvelink, Maria Ruiperez Gonzalez, Milan Kilibarda, Aleksandar Blagotić, Wei Shangguan, Marvin N. Wright, Xiaoyuan Geng, Bernhard Bauer-Marschallinger, Mario Antonio Guevara, Rodrigo Vargas, Robert A. MacMillan, Niels H. Batjes, Johan G. B. Leenaars, Eloi Ribeiro, Ichsani Wheeler, Stephan Mantel, and Bas Kempen. 2017. "SoilGrids250m: Global Gridded Soil Information Based on Machine Learning." PLoS ONE 12(2): 0169748.

Heudorfer, B., E. Haaf, K. Stahl, and R. Barthel. 2019. "Index-Based Characterization and Quantification of Groundwater Dynamics.” Water Resources Research 55(7):5575-92.

Houston, J. F. T. 1982. "Rainfall and Recharge to a Dolomite Aquifer in a Semi-Arid Climate at Kabwe, Zambia." Journal of Hydrology 59(1-2):173-87.

Howard, Ken W. F. and John Karundu. 1992. "Constraints on the Exploitation of Basement Aquifers in East Africa - Water Balance Implications and the Role of the Regolith.” Journal of Hydrology 139(1-4):183-96.

Ibrahim, Maïmouna, Guillaume Favreau, Bridget R. Scanlon, Jean Luc Seidel, Mathieu Le Coz, Jérôme Demarty, and Bernard Cappelaere. 2014. "Long-Term Increase in Diffuse Groundwater Recharge Following Expansion of Rainfed Cultivation in the Sahel, West Africa.” Hydrogeology Journal 22(6):1293-1305.

Jacks, Gunnar and Matallah S. Traoré. 2014. "Mechanisms and Rates of Groundwater Recharge at Timbuktu, Republic of Mali.” Journal of Hydrologic Engineering 19(2):422-27.

Jasechko, Scott, S.Jean Birks, Tom Gleeson, Yoshihide Wada, Peter J. Fawcett, Zachary D. Sharp, Jeffrey J. McDonnell, and Jeffrey M. Welker. 2014. "The Pronounced Seasonality of Global Groundwater Recharge.” Water Resources Research 50(11):8845-67.

Jasechko, Scott, Debra Perrone, Kevin M. Befus, M. Bayani Cardenas, Grant Ferguson, Tom Gleeson, 
Elco Luijendijk, Jeffrey J. McDonnell, Richard G. Taylor, Yoshihide Wada, and James W. Kirchner. 2017. "Global Aquifers Dominated by Fossil Groundwaters but Wells Vulnerable to Modern Contamination.” Nature Geoscience 10(6):425-29.

Jasechko, Scott and Richard G. Taylor. 2015. "Intensive Rainfall Recharges Tropical Groundwaters." Environmental Research Letters 10(12):124015.

Jenny, Hans. 1941. Factors of Soil Formation. A System of Quantitative Pedology, Soil Science.

Kamtchueng, Brice Tchakam, Wilson Yetoh Fantong, Mengnjo Jude Wirmvem, Rosine Edwige Tiodjio, Alain Fouépé Takounjou, Kazuyoshi Asai, Serges L. Bopda Djomou, Minoru Kusakabe, Takeshi Ohba, Gregory Tanyileke, Joseph Victor Hell, and Akira Ueda. 2015. “A Multi-Tracer Approach for Assessing the Origin, Apparent Age and Recharge Mechanism of Shallow Groundwater in the Lake Nyos Catchment, Northwest, Cameroon.” Journal of Hydrology 523:790-803.

Kebede, Seifu, Yves Travi, Tamiru Alemayehu, and Tenalem Ayenew. 2005. "Groundwater Recharge, Circulation and Geochemical Evolution in the Source Region of the Blue Nile River, Ethiopia." Applied Geochemistry 20(9):1658-76.

Kim, John H. and Robert B. Jackson. 2012. "A Global Analysis of Groundwater Recharge for Vegetation, Climate, and Soils.” Vadose Zone Journal 11(1).

Knoben, Wouter J. M., Ross A. Woods, and Jim E. Freer. 2018. “A Quantitative Hydrological Climate Classification Evaluated With Independent Streamflow Data." Water Resources Research 54(7):5088-5109.

Kotchoni, D. O.Valeri., Jean Michel Vouillamoz, Fabrice M. A. Lawson, Philippe Adjomayi, Moussa Boukari, and Richard G. Taylor. 2018. "Relationships between Rainfall and Groundwater Recharge in Seasonally Humid Benin: A Comparative Analysis of Long-Term Hydrographs in Sedimentary and Crystalline Aquifers." Hydrogeology Journal 27:447-457.

Lapworth, D. J., A. M. MacDonald, M. N. Tijani, W. G. Darling, D. C. Gooddy, H. C. Bonsor, and L. 
J. Araguás-Araguás. 2013. "Residence Times of Shallow Groundwater in West Africa: Implications for Hydrogeology and Resilience to Future Changes in Climate.” Hydrogeology Journal 21:673-686.

Lapworth, D. J., D. C. W. Nkhuwa, J. Okotto-Okotto, S. Pedley, M. E. Stuart, M. N. Tijani, and J. Wright. 2017. "Urban Groundwater Quality in Sub-Saharan Africa: Current Status and Implications for Water Security and Public Health.” Hydrogeology Journal 25:1093-1116.

Leblanc, Marc J., Guillaume Favreau, Sylvain Massuel, Sarah O. Tweed, Maud Loireau, and Bernard Cappelaere. 2008. "Land Clearance and Hydrological Change in the Sahel: SW Niger." Global and Planetary Change 61(3-4):135-50.

Leduc, C., G. Favreau, and P. Schroeter. 2001. “Long-Term Rise in a Sahelian Water-Table: The Continental Terminal in South-West Niger.” Journal of Hydrology 243(1):43-54.

Lehner, B., K. Verdin, and A. Jarvis. 2013. "HydroSHEDS Technical Documentation Version 1.2.” EOS Transactions 89(10):26.

Lehner, Bernhard and Petra Döll. 2004. "Development and Validation of a Global Database of Lakes, Reservoirs and Wetlands." Journal of Hydrology 296(1-4):1-22.

Leketa, Khahliso, Tamiru Abiye, Silindile Zondi, and Michael Butler. 2019. “Assessing Groundwater Recharge in Crystalline and Karstic Aquifers of the Upper Crocodile River Basin, Johannesburg, South Africa." Groundwater for Sustainable Development 8:31-40.

Lentswe, Gaolatlhe Bhutto and Loago Molwalefhe. 2020. "Delineation of Potential Groundwater Recharge Zones Using Analytic Hierarchy Process-Guided GIS in the Semi-Arid Motloutse Watershed, Eastern Botswana.” Journal of Hydrology: Regional Studies 28.

Lerner, David N. 2002. “Identifying and Quantifying Urban Recharge: A Review.” Hydrogeology Journal 10(1):143-52.

M.I, Budyko. 1974. Climate and Life. Academic Press, New York. 
MacDonald, A. M., H. C. Bonsor, B. É. Ó. Dochartaigh, and R. G. Taylor. 2012. "Quantitative Maps of Groundwater Resources in Africa.” Environmental Research Letters 7(24009).

MacDonald, A. M. and R. C. Calow. 2009. "Developing Groundwater for Secure Rural Water Supplies in Africa." Desalination 248(1-3):546-56.

MacDonald, Alan M., R.Murray Lark, Richard G. Taylor, Tamiru Abiye, Helen C. Fallas, Guillaume Favreau, Ibrahim B. Goni, Seifu Kebede, Bridget Scanlon, James P. R. Sorensen, Moshood Tijani, Kirsty A. Upton, and Charles West. 2021. "Mapping Groundwater Recharge in Africa from Ground Observations and Implications for Water Security.” Environmental Research Letters 16(34012).

Mao, J. and B. Yan. 2019. “Global Monthly Mean Leaf Area Index Climatology, 1981-2015.” ORNL DAAC, Oak Ridge, Tennessee, USA. Retrieved (https://daac.ornl.gov/VEGETATION/guides/Mean_Seasonal_LAI.html).

Mayaux, Philippe, Etienne Bartholomé, Steffen Fritz, and Alan Belward. 2004. “A New Land-Cover Map of Africa for the Year 2000.” Journal of Biogeography 31(6):861-77.

Mazor, E., B.Th Verhagen, J. P. F. Sellschop, M. T. Jones, N. E. Robins, L. Hutton, and C. M. H. Jennings. 1977. "Northern Kalahari Groundwaters: Hydrologic, Istopic and Chemical Studies at Orapa, Botswana." Journal of Hydrology 34(3-4):203-34.

Mazor, Emanuel. 1982. "Rain Recharge in the Kalahari - A Note on Some Approaches to the Problem." Journal of Hydrology 55(1-4):137-44.

McKenna, Owen P. and Osvaldo E. Sala. 2018. "Groundwater Recharge in Desert Playas: Current Rates and Future Effects of Climate Change.” Environmental Research Letters 13(1):14025.

Measho, Simon, Baozhang Chen, Yongyut Trisurat, Petri Pellikka, Lifeng Guo, Sunsanee Arunyawat, Venus Tuankrua, Woldeselassie Ogbazghi, and Tecle Yemane. 2019. "Spatio-Temporal Analysis of Vegetation Dynamics as a Response to Climate Variability and Drought Patterns in the Semiarid Region, Eritrea." Remote Sensing 11(6). 
Mechal, Abraham, Thomas Wagner, and Steffen Birk. 2015. "Recharge Variability and Sensitivity to Climate: The Example of Gidabo River Basin, Main Ethiopian Rift.” Journal of Hydrology: Regional Studies 4(B):644-60.

Melanie A. Harsch, Philip E. Hulme, Matt S. McGlone, and Richard P. Duncan. 2009. "Are Treelines Advancing? A Global Meta-Analysis of Treeline Response to Climate Warming.” Ecology Letters 12(10):1040-49.

Miralles, Diego G., John H. Gash, Thomas R. H. Holmes, Richard A. M. De Jeu, and A. J. Dolman. 2010. "Global Canopy Interception from Satellite Observations.” Journal of Geophysical Research Atmospheres 115(D16122).

Moeck, Christian, Nicolas Grech-Cumbo, Joel Podgorski, Anja Bretzler, Jason J. Gurdak, Michael Berg, and Mario Schirmer. 2020. “A Global-Scale Dataset of Direct Natural Groundwater Recharge Rates: A Review of Variables, Processes and Relationships.” Science of the Total Environment 717(137042).

Mohan, Chinchu, Andrew W. Western, Yongping Wei, and Margarita Saft. 2018. "Predicting Groundwater Recharge for Varying Land Cover and Climate Conditions-a Global Meta-Study.” Hydrology and Earth System Sciences 22(5):2689-2703.

Moon, Sang Ki, Nam C. Woo, and Kwang S. Lee. 2004. "Statistical Analysis of Hydrographs and Water-Table Fluctuation to Estimate Groundwater Recharge.” Journal of Hydrology 292(14):198-209.

Morin, Efrat, Tamir Grodek, Ofer Dahan, Gerardo Benito, Christoph Kulls, Yael Jacoby, Guido Van Langenhove, Mary Seely, and Yehouda Enzel. 2009. "Flood Routing and Alluvial Aquifer Recharge along the Ephemeral Arid Kuiseb River, Namibia." Journal of Hydrology 368(14):262-75.

Nash, David J., Paul A. Shaw, and David S. G. Thomas. 1994. "Duricrust Development and Valley Evolution: Process-landform Links in the Kalahari." Earth Surface Processes and Landforms 
Ndehedehe, Christopher E., Vagner G. Ferreira, and Nathan O. Agutu. 2019. "Hydrological Controls on Surface Vegetation Dynamics over West and Central Africa." Ecological Indicators 103:494-508.

Nicholson, S. E. 2000. "The Nature of Rainfall Variability over Africa on Time Scales of Decades to Millenia." Global and Planetary Change 26(1-3):137-58.

Nicholson, Sharon E. and Jeeyoung Kim. 1997. "The Relationship of the El MNO-Southern Oscillation to African Rainfall.” International Journal of Climatology 17(2):117-35.

Nijzink, Remko, Christopher Hutton, Ilias Pechlivanidis, René Capell, Berit Arheimer, Jim Freer, Dawei Han, Thorsten Wagener, Kevin McGuire, Hubert Savenije, and Markus Hrachowitz. 2016. "The Evolution of Root-Zone Moisture Capacities after Deforestation: A Step towards Hydrological Predictions under Change?" Hydrology and Earth System Sciences 20(12):477599.

Nkotagu, Hudson. 1996. “Application of Environmental Isotopes to Groundwater Recharge Studies in a Semi-Arid Fractured Crystalline Basement Area of Dodoma, Tanzania." Journal of African Earth Sciences 22(4):443-57.

NOAA/OAR/ESRL PSD. n.d. “CPC Global Temperature Data.” Retrieved June 10, 2020 (https://psl.noaa.gov/data/gridded/data.cpc.globaltemp.html).

Olson, D. M., Thomas F. Allnutt, Taylor H. Ricketts, Y. U. M. I. K. O. Kura, John F. Lamoreux, W. Wesley, Prashant Hedao, and Kenneth R. Kassem. 2001. "Terrestrial Ecoregions of the World: A New Map of Life on Earth.” BioScience 51(11):933-38.

Osunbitan, J. A., D. J. Oyedele, and K. O. Adekalu. 2005. "Tillage Effects on Bulk Density, Hydraulic Conductivity and Strength of a Loamy Sand Soil in Southwestern Nigeria." Soil and Tillage Research 82(1):57-64.

Oteng Mensah, Felix, Clement Alo, and Sandow Mark Yidana. 2014. "Evaluation of Groundwater 

Recharge Estimates in a Partially Metamorphosed Sedimentary Basin in a Tropical Environment: Application of Natural Tracers.” The Scientific World Journal 2014(419508).

Owor, M., R. G. Taylor, C. Tindimugaya, and D. Mwesigwa. 2009. "Rainfall Intensity and Groundwater Recharge: Empirical Evidence from the Upper Nile Basin.” Environmental Research Letters 4(35009).

Peel, M. C., B. L. Finlayson, and T. A. McMahon. 2007. "Updated World Map of the Köppen-Geiger Climate Classification." Hydrology and Earth System Sciences 11(5):1633-44.

Pelletier, Jon D., Greg A. Barron-Gafford, David D. Breshears, Paul D. Brooks, Jon Chorover, Matej Durcik, Ciaran J. Harman, Travis E. Huxman, Kathleen A. Lohse, Rebecca Lybrand, Tom Meixner, Jennifer C. McIntosh, Shirley A. Papuga, Craig Rasmussen, Marcel Schaap, Tyson L. Swetnam, and Peter A. Troch. 2013. "Coevolution of Nonlinear Trends in Vegetation, Soils, and Topography with Elevation and Slope Aspect: A Case Study in the Sky Islands of Southern Arizona.” Journal of Geophysical Research: Earth Surface 118(2):741-58.

Pelletier, Jon D., Patrick D. Broxton, Pieter Hazenberg, Xubin Zeng, Peter A. Troch, Guo Yue Niu, Zachary Williams, Michael A. Brunke, and David Gochis. 2016. "A Gridded Global Data Set of Soil, Intact Regolith, and Sedimentary Deposit Thicknesses for Regional and Global Land Surface Modeling." Journal of Advances in Modeling Earth Systems 8(1):41-65.

Quichimbo, E.Andres, Michael Bliss Singer, Katerina Michaelides, D. Hobley, Rosolem, Rafael, and M. O. Cuthbert. 2021. "DRYP 1.0: A Parsimonious Hydrological Model of DRYland Partitioning of the Water Balance.” Geoscientific Model Development 14(11):6893-6917.

Rao Kolusu, Seshagiri, Mohammad Shamsudduha, Martin C. Todd, Richard G. Taylor, David Seddon, Japhet J. Kashaigili, Girma Y. Ebrahim, Mark O. Cuthbert, James P. R. Sorensen, Karen G. Villholth, Alan M. Macdonald, and Dave A. Macleod. 2019. "The El Niño Event of 2015-2016: Climate Anomalies and Their Impact on Groundwater Resources in East and Southern Africa." Hydrology and Earth System Sciences 23(3):1751-62. 
Reinecke, Robert, Hannes Müller Schmied, Tim Trautmann, Lauren Seaby Andersen, Peter Burek, Martina Flörke, Simon N. Gosling, Manolis Grillakis, Naota Hanasaki, Aristeidis Koutroulis, Yadu Pokhrel, Wim Thiery, Yoshihide Wada, Satoh Yusuke, and Petra Döll. 2021. "Uncertainty of Simulated Groundwater Recharge at Different Global Warming Levels: A Global-Scale Multi-Model Ensemble Study.” Hydrology and Earth System Sciences 25(2):787-810.

Reinhardt, Liam, Douglas Jerolmack, Brad J. Cardinale, Veerle Vanacker, and Justin Wright. 2010. "Dynamic Interactions of Life and Its Landscape: Feedbacks at the Interface of Geomorphology and Ecology." Earth Surface Processes and Landforms 35(1):78-101.

Robins, N. S., J. Davies, J. L. Farr, and R. C. Calow. 2006. “The Changing Role of Hydrogeology in Semi-Arid Southern and Eastern Africa.” Hydrogeology Journal 14:1483-1492.

Rueedi, J., M. S. Brennwald, R. Purtschert, U. Beyerle, M. Hofer, and R. Kipfer. 2005. "Estimating Amount and Spatial Distribution of Groundwater Recharge in the Lullemmeden Basin (Niger) Based on 3H, 3He and CFC-11 Measurements.” Hydrological Processes 19(17):3285-98.

Sarrazin, Fanny, Andreas Hartmann, Francesca Pianosi, Rafael Rosolem, and Thorsten Wagener. 2018. "V2Karst V1.1: A Parsimonious Large-Scale Integrated Vegetation-Recharge Model to Simulate the Impact of Climate and Land Cover Change in Karst Regions." Geoscientific Model Development 11(12):4933-64.

Sawicz, K. A., C. Kelleher, T. Wagener, P. Troch, M. Sivapalan, and G. Carrillo. 2014. "Characterizing Hydrologic Change through Catchment Classification." Hydrology and Earth System Sciences 18(1):273-285.

Sawicz, K., T. Wagener, M. Sivapalan, P. A. Troch, and G. Carrillo. 2011. "Catchment Classification: Empirical Analysis of Hydrologic Similarity Based on Catchment Function in the Eastern USA.” Hydrology and Earth System Sciences 15(9):2895-2911.

Saxton, K. E., W. J. Rawls, J. S. Romberger, and R. I. Papendick. 1986. “Estimating Generalized Soil-Water Characteristics from Texture.” Soil Science Society of America Journal 50(4):1031- 
Scanlon, Bridget R., Richard W. Healy, and Peter G. Cook. 2002. "Choosing Appropriate Techniques for Quantifying Groundwater Recharge.” Hydrogeology Journal 10:18-39.

Scanlon, Bridget R., Ian Jolly, Marios Sophocleous, and Lu Zhang. 2007. “Global Impacts of Conversions from Natural to Agricultural Ecosystems on Water Resources: Quantity versus Quality.” Water Resources Research 43(3).

Schlesinger, William H. and Scott Jasechko. 2014. "Transpiration in the Global Water Cycle." Agricultural and Forest Meteorology 189-190:115-17.

Scott, Russell L., Travis E. Huxman, William L. Cable, and William E. Emmerich. 2006. "Partitioning of Evapotranspiration and Its Relation to Carbon Dioxide Exchange in a Chihuahuan Desert Shrubland.” Hydrological Processes 20(15):3227-43.

Seddon, David, Japhet J. Kashaigili, Richard G. Taylor, Mark O. Cuthbert, Catherine Mwihumbo, and Alan M. MacDonald. 2021. "Focused Groundwater Recharge in a Tropical Dryland: Empirical Evidence from Central, Semi-Arid Tanzania.” Journal of Hydrology: Regional Studies 37.

Sharp, John M. 2010. "The Impacts of Urbanization on Groundwater Systems and Recharge.” Aquamundi 1(may):51-56.

Siam, Mohamed S. and Elfatih A. B. Eltahir. 2017. "Climate Change Enhances Interannual Variability of the Nile River Flow." Nature Climate Change 7(5):350-54.

Sibanda, Tenant, Johannes C. Nonner, and Stefan Uhlenbrook. 2009. "Comparison of Groundwater Recharge Estimation Methods for the Semi-Arid Nyamandhlovu Area, Zimbabwe.” Hydrogeology Journal 17(6):1427-41.

Sidibe, Moussa, Bastien Dieppois, Jonathan Eden, Gil Mahé, Jean Emmanuel Paturel, Ernest Amoussou, Babatunde Anifowose, and Damian Lawler. 2019. "Interannual to Multi-Decadal Streamflow Variability in West and Central Africa: Interactions with Catchment Properties and Large-Scale Climate Variability.” Global and Planetary Change 177:141-56. 
Siebert, S., Döll, P., Feick, S., Frenken, K., Hoogeveen, J. 2013. Global Map of Irrigation Areas Version 5. Rome.

Siebert, S., M. Kummu, M. Porkka, P. Döll, N. Ramankutty, and B. R. Scanlon. 2015. “A Global Data Set of the Extent of Irrigated Land from 1900 to 2005." Hydrology and Earth System Sciences 19(3):1521-45.

Simmers, I. 1990. “Aridity, Groundwater Recharge and Water Resources Management.” Pp. 1-20 in Groundwater recharge: a Guide to Recharge Measurement in Arid and Semiarid Regionsunderstanding and estimating natural recharge.

Spaan, W. P., A. F. S. Sikking, and W. B. Hoogmoed. 2005. "Vegetation Barrier and Tillage Effects on Runoff and Sediment in an Alley Crop System on a Luvisol in Burkina Faso." Soil and Tillage Research 83(2):194-203.

Stein, L., M. P. Clark, W. J. M. Knoben, F. Pianosi, and R. A. Woods. 2021. "How Do Climate and Catchment Attributes Influence Flood Generating Processes? A Large-Sample Study for 671 Catchments Across the Contiguous USA.” Water Resources Research 57(4):e2020WR028300.

Steward, Alisha L., Daniel Von Schiller, Klement Tockner, Jonathan C. Marshall, and Stuart E. Bunn. 2012. "When the River Runs Dry: Human and Ecological Values of Dry Riverbeds." Frontiers in Ecology and the Environment 10(4):202-9.

Stone, A. E. C. and W. M. Edmunds. 2012. "Sand, Salt and Water in the Stampriet Basin, Namibia: Calculating Unsaturated Zone (Kalahari Dunefield) Recharge Using the Chloride Mass Balance Approach." Water SA 38(3):367-78.

Strudley, Mark W., Timothy R. Green, and James C. Ascough. 2008. “Tillage Effects on Soil Hydraulic Properties in Space and Time: State of the Science." Soil and Tillage Research 99(1):4-48.

Sturchio, N. C., X. Du, R. Purtschert, B. E. Lehmann, M. Sultan, L. J. Patterson, Z. T. Lu, P. Müller, T. Bigler, K. Bailey, T. P. O’Connor, L. Young, R. Lorenzo, R. Becker, Z. El Alfy, B. El 

Kaliouby, Y. Dawood, and A. M. A. Abdallah. 2004. "One Million Year Old Groundwater in the Sahara Revealed by Krypton-81 and Chlorine-36." Geophysical Research Letters 31(L05503).

Sultan, M., N. C. Sturchio, H. Gheith, Y. Abdel Hady, and M. El Anbeawy. 2000. “Chemical and Isotopic Constraints on the Origin of Wadi El-Tarfa Ground Water, Eastern Desert, Egypt.” Ground Water 38(5):743-51.

Sultan, M., E. Yan, N. Sturchio, A. Wagdy, K. Abdel Gelil, R. Becker, N. Manocha, and A. Milewski. 2007. "Natural Discharge: A Key to Sustainable Utilization of Fossil Groundwater." Journal of Hydrology 335(1-2):25-36.

Tantawi, M. A., E. El-Sayed, and M. A. Awad. 1998. "Hydrochemical and Stable Isotope Study of Groundwater in the Saint Catherine-Wadi Feiran Area, South Sinai, Egypt." Journal of African Earth Sciences 26(2):277-84.

Taylor, Richard G. and Ken W. F. Howard. 1996. "Groundwater Recharge in the Victoria Nile Basin of East Africa: Support for the Soil Moisture Balance Approach Using Stable Isotope Tracers and Flow Modelling." Journal of Hydrology 180(1-4):31-53.

Taylor, Richard G., Martin C. Todd, Lister Kongola, Louise Maurice, Emmanuel Nahozya, Hosea Sanga, and Alan M. Macdonald. 2013. "Evidence of the Dependence of Groundwater Resources on Extreme Rainfall in East Africa." Nature Climate Change 3:374-378.

Telteu, Camelia-Eliza, Hannes Müller Schmied, Wim Thiery, Guoyong Leng, Peter Burek, Xingcai Liu, Julien Eric Stanislas Boulange, Lauren Seaby Andersen, Manolis Grillakis, Simon Newland Gosling, Yusuke Satoh, Oldrich Rakovec, Tobias Stacke, Jinfeng Chang, Niko Wanders, Harsh Lovekumar Shah, Tim Trautmann, Ganquan Mao, Naota Hanasaki, Aristeidis Koutroulis, Yadu Pokhrel, Luis Samaniego, Yoshihide Wada, Vimal Mishra, Junguo Liu, Petra Döll, Fang Zhao, Anne Gädeke, Sam Rabin, and Florian Herz. 2021. “Understanding Each Other's Models: A Standard Representation of Global Water Models to Support Improvement, Intercomparison, and Communication." Geoscientific Model Development Discussions 1-56. 
Telteu, Camelia Eliza, Hannes Müller Schmied, Wim Thiery, Guoyong Leng, Peter Burek, Xingcai Liu, Julien Eric Stanislas Boulange, Lauren Seaby Andersen, Manolis Grillakis, Simon Newland Gosling, Yusuke Satoh, Oldrich Rakovec, Tobias Stacke, Jinfeng Chang, Niko Wanders, Harsh Lovekumar Shah, Tim Trautmann, Ganquan Mao, Naota Hanasaki, Aristeidis Koutroulis, Yadu Pokhrel, Luis Samaniego, Yoshihide Wada, Vimal Mishra, Junguo Liu, Petra Döll, Fang Zhao, Anne Gädeke, Sam S. Rabin, and Florian Herz. 2021. "Understanding Each Other’s Models An Introduction and a Standard Representation of 16 Global Water Models to Support Intercomparison, Improvement, and Communication." Geoscientific Model Development 14(6):3843-78.

Thierfelder, Christian and Patrick C. Wall. 2009. "Effects of Conservation Agriculture Techniques on Infiltration and Soil Water Content in Zambia and Zimbabwe." Soil and Tillage Research 105(2):217-27.

Thompson, S. E., C. J. Harman, P. Heine, and G. G. Katul. 2010. "Vegetation-Infiltration Relationships across Climatic and Soil Type Gradients." Journal of Geophysical Research: Biogeosciences 115(G02023).

du Toit, G.van N., H. A. Snyman, and P. J. Malan. 2009. "Physical Impact of Grazing by Sheep on Soil Parameters in the Nama Karoo Subshrub/grass Rangeland of South Africa." Journal of Arid Environments 73(9):804-10.

Van Tonder, G. J. and J. Kirchner. 1990. "Estimation of Natural Groundwater Recharge in the Karoo Aquifers of South Africa." Journal of Hydrology 121(1-4):395-419.

Towett, Erick K., Keith D. Shepherd, Jerome E. Tondoh, Leigh A. Winowiecki, Tamene Lulseged, Mercy Nyambura, Andrew Sila, Tor G. Vågen, and Georg Cadisch. 2015. “Total Elemental Composition of Soils in Sub-Saharan Africa and Relationship with Soil Forming Factors.” Geoderma Regional 5:157-68.

Troch, P. A., G. Carrillo, M. Sivapalan, T. Wagener, and K. Sawicz. 2013. "Climate-Vegetation-Soil Interactions and Long-Term Hydrologic Partitioning: Signatures of Catchment Co-Evolution.” 
Tsendbazar, Nandin Erdene, Sytze de Bruin, and Martin Herold. 2017. "Integrating Global Land Cover Datasets for Deriving User-Specific Maps.” International Journal of Digital Earth 10(3):219-37.

Været, Lars, Bruce Kelbe, Sylvi Haldorsen, and Richard H. Taylor. 2009. "A Modelling Study of the Effects of Land Management and Climatic Variations on Groundwater Inflow to Lake St Lucia, South Africa." Hydrogeology Journal 17(8):1949-67.

Vogel, J. C. and H. Van Urk. 1975. "Isotopic Composition of Groundwater in Semi-Arid Regions of Southern Africa." Journal of Hydrology 25(1-2):23-36.

de Vries, J. and A. Gieske. 1990. “A Simple Chloride Balance Routing Method to Regionalize Groundwater Recharge: A Case Study in Semiarid Botswana.” Pp. 81-89 in Regionalization in Hydrolo. he Ljubljan: IAHS Publ. no. 191.

De Vries, J. J., E. T. Selaolo, and H. E. Beekman. 2000. "Groundwater Recharge in the Kalahari, with Reference to Paleo-Hydrologic Conditions.” Journal of Hydrology 238(1-2):110-23.

Wagener, T., T. Gleeson, Gemma Coxon, A. Hartmann, N. J. K. Howden, F. Pianosi, R. Rosolem, L. Stein, and R. A. Woods. 2021. "On Doing Hydrology with Dragons: Realizing the Value of Perceptual Models and Knowledge Accumulation.” WIREs WATER (e1550).

Wakindiki, I. I. C. and M. Ben-Hur. 2002. "Soil Mineralogy and Texture Effects on Crust Micromorphology, Infiltration, and Erosion.” Soil Science Society of America Journal 66(3):897-905.

Walker, David, Magdalena Smigaj, and Nebo Jovanovic. 2019. "Ephemeral Sand River Flow Detection Using Satellite Optical Remote Sensing.” Journal of Arid Environments 168:17-25.

Walraevens, Kristine, Ine Vandecasteele, Kristine Martens, Jan Nyssen, Jan Moeyersons, Tesfamichael Gebreyohannes, Florimond de Smedt, Jean Poesen, Jozef Deckers, and Marc van Camp. 2009. "Groundwater Recharge and Flow in a Small Mountain Catchment in Northern 
Wang, Shengping, Tim R. McVicar, Zhiqiang Zhang, Thomas Brunner, and Peter Strauss. 2020. "Globally Partitioning the Simultaneous Impacts of Climate-Induced and Human-Induced Changes on Catchment Streamflow: A Review and Meta-Analysis.” Journal of Hydrology 590.

Wanke, Heike, Armin Dünkeloh, and Peter Udluft. 2008. "Groundwater Recharge Assessment for the Kalahari Catchment of North-Eastern Namibia and North-Western Botswana with a RegionalScale Water Balance Model.” Water Resources Management 22:1143-1158.

Williams, Paul W. and Derek C. Ford. 2006. "Global Distribution of Carbonate Rocks.” Zeitschrift Fur Geomorphologie, Supplementband 147(1-2).

Winter, Thomas C. 2001. "The Concept of Hydrologic Landscapes." Journal of the American Water Resources Association 37(2):335-49.

Wirmvem, Mengnjo Jude, Mumbfu Ernestine Mimba, Brice Tchakam Kamtchueng, Engome Regina Wotany, Tasin Godlove Bafon, Asobo Nkengmatia Elvis Asaah, Wilson Yetoh Fantong, Samuel Ndonwi Ayonghe, and Takeshi Ohba. 2015. "Shallow Groundwater Recharge Mechanism and Apparent Age in the Ndop Plain, Northwest Cameroon.” Applied Water Science 7(1):489-502.

Wolock, David M., Thomas C. Winter, and Gerard McMahon. 2004. "Delineation and Evaluation of Hydrologic-Landscape Regions in the United States Using Geographic Information System Tools and Multivariate Statistical Analyses." Environmental Management.

Wolski, P., H. H. G. Savenije, M. Murray-Hudson, and T. Gumbricht. 2006. "Modelling of the Flooding in the Okavango Delta, Botswana, Using a Hybrid Reservoir-GIS Model.” Journal of Hydrology 331(1-2):58-72.

Wösten, J. H. M., Ya A. Pachepsky, and W. J. Rawls. 2001. "Pedotransfer Functions: Bridging the Gap between Available Basic Soil Data and Missing Soil Hydraulic Characteristics.” Journal of Hydrology 251(3-4):123-50.

Xiong, Jun, Prasad S. Thenkabail, Murali K. Gumma, Pardhasaradhi Teluguntla, Justin Poehnelt, 
Russell G. Congalton, Kamini Yadav, and David Thau. 2017. “Automated Cropland Mapping of Continental Africa Using Google Earth Engine Cloud Computing." ISPRS Journal of Photogrammetry and Remote Sensing 126:225-44.

Xu, Yongxin and Hans E. Beekman. 2003. Groundwater Recharge Estimation in Southern Africa. Vol. 64.

Yidana, Sandow Mark and Eric Koffie. 2014. "The Groundwater Recharge Regime of Some Slightly Metamorphosed Neoproterozoic Sedimentary Rocks: An Application of Natural Environmental Tracers." Hydrological Processes 28(7):3104-17.

Zarate, E., D. Hobley, A. M. MacDonald, R. T. Swift, J. Chambers, J. J. Kashaigili, E. Mutayoba, R. G. Taylor, and M. O. Cuthbert. 2021. "The Role of Superficial Geology in Controlling Groundwater Recharge in the Weathered Crystalline Basement of Semi-Arid Tanzania.” Journal of Hydrology: Regional Studies 36.

Zhang, Yongqiang, Jorge L. Peña-Arancibia, Tim R. McVicar, Francis H. S. Chiew, Jai Vaze, Changming Liu, Xingjie Lu, Hongxing Zheng, Yingping Wang, Yi Y. Liu, Diego G. Miralles, and Ming Pan. 2016. "Multi-Decadal Trends in Global Terrestrial Evapotranspiration and Its Components." Scientific Reports 6(19124).

Zheng, Chaolei, Li Jia, Guangcheng Hu, Massimo Menenti, Jing Lu, Jie Zhou, Kun Wang, and Zhansheng Li. 2017. "Assessment of Water Use in Pan-Eurasian and African Continents by ETMonitor with Multi-Source Satellite Data." in IOP Conference Series: Earth and Environmental Science. Vol. 57.

Zhou, Liming, Yuhong Tian, Ranga B. Myneni, Philippe Ciais, Sassan Saatchi, Yi Y. Liu, Shilong Piao, Haishan Chen, Eric F. Vermote, Conghe Song, and Taehee Hwang. 2014. "Widespread Decline of Congo Rainforest Greenness in the Past Decade.” Nature 508(7498):86-90.

Zhou, Yuyu, Steven J. Smith, Kaiguang Zhao, Marc Imhoff, Allison Thomson, Ben Bond-Lamberty, Ghassem R. Asrar, Xuesong Zhang, Chunyang He, and Christopher D. Elvidge. 2015. "A Global 
Zouari, Kamel, Rim Trabelsi, and Najiba Chkir. 2011. "Using Geochemical Indicators to Investigate Groundwater Mixing and Residence Time in the Aquifer System of Djeffara of Medenine (Southeastern Tunisia).” Hydrogeology Journal 19(1):209-19.

\section{Supplemental information}

\section{S1 Extended review of process controls on groundwater recharge across Africa}

Most of the existing knowledge base on groundwater recharge processes, controls and rates in Africa comes from a relatively small number of case studies investigating recharge at the field, catchment, or sometimes regional scale. We take an approach similar to that of Scanlon et al. (2006), where we record and describe the controls and mechanisms which the literature reports as controlling recharge processes. However, we look across the entire continent and not just dryland systems as is done by Scanlon et al. (2006).

A wide range of methods have been used to understand recharge processes throughout the continent, with approaches often varying according to environmental setting, data availability and the objective of the individual studies (MacDonald et al. 2021). The most commonly used field methods depend on chemical and isotopic tracers to understand recharge rates, controls and mechanisms; observations of water table fluctuations, dissolved anthropogenic gases or more rarely baseflow separation of river flows are also used. Others also take modelling approaches including soil moisture balance approaches or water balance modelling. Details of the strengths and weaknesses of the different methods can be found in Scanlon et al. (2002) and Healy (2010). A small number of studies have begun to use findings from these approaches to investigate how and why groundwater recharge processes vary across continental or global scales or within certain eco-hydrological zones. Generally, these studies have approached this by compiling datasets of recharge estimates from across the world (Kim and Jackson 2012; Moeck et al. 2020) or by trying to understand recharge mechanisms in greater detail at a much small number of sites (Mark O. Cuthbert et al. 2019; Jasechko et al. 2014; Jasechko and Taylor 2015).

We organize the review of controls into four domains: climate/weather, topography, landcover/use, soils/geology. We initially try to understand the independent effects of each control to recharge and later discuss the interaction of each of the controls and how they define different landscapes in which recharge processes may differ.

\section{S1.1 Climate and weather}

The frequency with which groundwater recharge occurs generally varies in-line with the climate gradient (Cuthbert et al., 2019). In humid and sub-humid regions, recharge reliably occurs seasonally or at least inter-annually. In contrast, groundwater stores in arid environments are much more dependent upon episodic rainfall events of great intensity and may largely contain water recharged in previous pluvial flood periods (Sturchio et al. 2004; Sultan et al. 1997). We therefore use the timescale at which groundwater recharge occurs as 
a means of organising our findings on the role of climate and weather in controlling groundwater recharge in Africa.

Annual scale components of the water-energy balance are considered a first order control on the spatial variability of groundwater recharge (Cuthbert et al., 2019; Kim and Jackson, 2012; Mohan et al., 2018), as they control the quantity of water available to be partitioned into groundwater recharge, as well as the energy available to control atmospheric losses (Budyko, 1974). Globally, (Kim and Jackson 2012) found annual scale climate controls explained 41\% of the spatial variability in recharge rates they compiled from the literature, more than any other type of control. In the desert regions of Northern and Southern Africa, where annual rainfall is typically less than $400 \mathrm{~mm} /$ year (Nicholson 2000), recharge estimates generally remain below 5mm/year (Dabous and Osmond 2001; Foster et al. 1982; Zouari, Trabelsi, and Chkir 2011). Whilst in the central Highlands of Ethiopia, where annual rainfall can be as high as $1300 \mathrm{~mm} /$ year, recharge rates of $160 \mathrm{~mm} /$ year to $330 \mathrm{~mm} /$ year have been reported (Azagegn et al. 2015; Banks et al. 2021; Demlie 2015). Recharge rates of up to $940 \mathrm{~mm} /$ year have been reported in a tropical upland catchment in Cameroon, where annual rainfall is in excess of $3000 \mathrm{~mm} /$ year (Kamtchueng et al. 2015). Across a broad range of aridity conditions, Cuthbert et al. (2019) observe increasing annual recharge with annual precipitation in excess of some site specific threshold, though this relationships is not evident at the most humid or arid sites. In the Botswanan Kalahari, groundwater recharge is believed to depend upon annual rainfall exceeding $450 \mathrm{~mm} /$ year, with water in excess to evaporative demand being stored in thick sands and used by vegetation in subsequent dry periods (Foster et al. 1982). Exceeding these annual rainfall thresholds can often depend upon intense seasonal rains in which much of the years precipitation is concentrated (Mechal, Wagner, and Birk 2015; Taylor et al. 2013; Wirmvem et al. 2015).

Across Africa, groundwater recharge volumes are biased towards rainy season as elevated rainfall is required to overcome high rates of evapotranspiration (Bromley et al. 1997; Demlie et al. 2007; Jasechko et al. 2014; Walraevens et al. 2009). Where precipitation follows a bimodal regime, such as in the equatorial regions (Knoben et al., 2019), the season with the longest duration often produces the most groundwater recharge (Kebede et al., 2005; Owor et al., 2009; Mechal et al., 2015). Throughout these seasons, elevated precipitation intensities lead to a more efficient conversion of rainfall to recharge (Jasechko et al. 2014; Jasechko and Taylor 2015). In Uganda, monsoon rains in excess of $10 \mathrm{~mm} /$ day lead to seasonally enhanced recharge, contributing significantly to annual groundwater renewal (Owor et al. 2009; Taylor and Howard 1996). At sites in Ethiopia, Tanzania and Mali, recharge mainly occurs in months where rainfall is in excess of $240 \mathrm{~mm}, 210 \mathrm{~mm}$ and $140 \mathrm{~mm}$, respectively (Jasechko and Taylor 2015). Groundwater level observations in the Makutapora wellfield, Tanzania, suggest recharge is dependent upon months with the most extreme ( $>95^{\text {th }}$ percentile) rainfall (Taylor et al. 2013).

Furthermore, Taylor et al. (2013) found that five of the seven largest recharge events coincided with seasonal rains enhanced by the El Nino Southern Oscillation and the Indian Ocean Dipole. The Pacific Decadal and North Atlantic Oscillations are also known to effect climate patterns in Africa, albeit in different regions (Brown, de Beurs, and Vrieling 2010). These large-scale climate oscillations, which are driven by variations in sea surface temperature, are also known to have opposite effects to climate in different parts of the continent. For example, in East Africa, El Nino (La Nina) events are associated to increased 
wetting (drying), in contrast to drying (wetting) in Southern Africa (Nicholson and Kim 1997). Cycles of wetting and drying are being reflected in observations of the groundwater hydrograph throughout Africa (Taylor et al., 2013; Cuthbert et al., 2019; Kolusu et al., 2019), showing both seasonally extreme recharge events as well as recharge events which are more episodic in nature.

Episodic rainfall events are particularly important in arid landscapes where recharge often depends upon a small number of days of intense rainfall (Vogel and Van Urk 1975; Wanke, Dünkeloh, and Udluft 2008). These more intense rainfall events can enable the rapid infiltration of water via preferential flow paths, thus limiting the influence of evapotranspiration during percolation (Mazor et al. 1977; Nkotagu 1996; Sibanda, Nonner, and Uhlenbrook 2009; Van Tonder and Kirchner 1990; De Vries, Selaolo, and Beekman 2000; Xu and Beekman 2003). Döll and Fiedler (2008) stressed the importance of heavy rainfall events in semi-arid and arid regions as they modelled groundwater recharge globally, applying a rainfall threshold of $10 \mathrm{~mm}$ /day to drylands, below which recharge could not occur. Having identified this threshold via an independent analysis of 25 chloride profile estimates of annual recharge distributed throughout the world and regional model estimates of recharge in Death Valley, California.

Throughout Africa's driest regions, its deserts, groundwater resources are not being actively recharged. Desert aquifers are typically dominated by deep 'fossil' groundwater resources; groundwater which was recharged over 12,000 years ago prior to the beginning of the Holocene (Sturchio et al., 2004; Guendouz et al., 2006; Abotalib et al., 2016; Jasechko et al., 2017). Across the Sahara, paleoclimate regimes have alternated between wet and dry cycles (Abotalib et al. 2016). In wet glacial periods, intensified paleo-winds brought moisture westerly across the desert from the Atlantic Ocean (Abouelmagd et al. 2012; Sultan et al. 1997), condensation of which subsequently led to the rising of groundwater levels and the development of paleo-surface waters such as lakes and swamps (Causse 1989). Between wet cycle glacial periods, the intensification of paleo-monsoons recharged aquifers (Pachur and Hoelzmann 2000; Yan and Petit-Maire 1994). Since the last glacial maximum, only an estimated $1 \%$ of groundwater volumes in these environments have been turned over, as rainfall renewal rates are extremely low (Befus et al. 2017).

\section{S1.2 Topography}

Landscape topography organizes the landscape into regions of predominantly diffuse, focused and mountain system recharge as discussed in the beginning of this section (Scanlon et al., 2006). Diffuse groundwater recharge we generally perceive to occur in plainlands and places which may only gently undulate, as rainfall infiltration into the subsurface can occur throughout the landscape with limited effects from topographic gradients (Yenehun et al., 2017; Moeck et al., 2020; Tilahun et al., 2020). Though the dominance of each recharge mechanism within a region also depends upon the interaction of topographic features with other recharge controls such as climate, landcover and soil. For example, in arid regions, episodic storms can reactivate ephemeral rivers and water can infiltrate as focussed recharge, despite negligible diffuse recharge in interfluve regions due to high evaporation (Favreau et al., 2009; Cuthbert et al., 2019).

\section{S1.2.1 Focussed Recharge}


$21 \%$ of precipitation in Africa is partitioned to runoff which then feeds the continent's surface water systems of rivers, wetlands and lakes (Schmied et al. 2016). When connected to the groundwater system this can lead to focussed recharge, though not all groundwatersurface interactions promote this recharge mechanism. In systems where the aquifer and surface water store are connected by a continuous saturated zone, both groundwater exfiltration (gaining) and surface water infiltration (losing) may occur (Brunner, Cook, and Simmons 2009; Ivkovic 2009; Winter et al. 1998). In some rivers, the state of losing or gaining stream can vary between the different reaches of the river, whilst in wetlands and lakes the direction of flow can even vary across different parts of the bed (Sophocleous 2002; Winter et al. 1998). These states are not stationary but can vary in time and depend on the net-direction of hydrostatic forces acting at the bed of the surface water body (Winter et al. 1998). Surface and groundwater systems are disconnected when water tables are sufficiently deep that alterations to its position do not influence the infiltration rate (Brunner et al. 2009; Winter et al. 1998). In disconnected systems, surface waters generally lose water to the groundwater system (Ivkovic 2009). The connectivity between groundwater and surface water systems is largely controlled by climate, as in humid environments water tables are typically shallower (M. O. Cuthbert et al. 2019).

Satellite observations now show how the occurrence of water bodies in Africa has changed over the last 30 years (Pekel et al. 2016). Water bodies, which were once perennial have since become seasonal or ephemeral and vice versa. Further still, the distribution of surface water across the continent has changed, with the new water bodies being formed and previous ones disappearing (Donchyts et al. 2016). The occurrence of water bodies thus provides a useful starting point for organising the relationship between surface waters and focused groundwater recharge.

\section{Perennial}

Perennial streams predominantly gain water from groundwater inflows, i.e. baseflow (Gordon, McMahon, and Finlayson 2004). This may be well founded, as Beck et al. (2013) show that streamflow in dry Southern African regions are less dependent upon groundwater inflows than streams in tropical regions of the continent. However, the river Nile which is a perennial stream sourced in the Ethiopian Highlands, losses water to the groundwater system in the arid downstream reaches of Sudan and Egypt (Abdalla 2009). Therefore, transmission losses from perennial rivers likely depends upon local climate conditions.

Lakes store 0.03 million $\mathrm{km}^{3}$ of the Africa's water (Shiklomanov and Rodda 2004), a volume approximately 7.5 times the magnitude of annual freshwater renewability on the continent (FAO 2018; MacDonald et al. 2012; UNEP 2010) and almost entirely attributed to the Great Lakes of Eastern Africa. Owor et al., (2011) used piezometric data to investigate groundwater flows along the northern shores of Lake Victoria and Lake Kyoga in Uganda. They found that the along the stretches of shoreline they studied groundwater predominantly discharged into the lake. On the North Western Ethiopian Plateau, Kebede et al., (2005) suggest that groundwater was flowing towards Lake Tana due to the dipping of geology towards the lake. Other Lakes such as Lake Naivasha in Kenya and the Kosi Bay Lakes in South Africa exhibit though flow processes where regional groundwater discharges into the lake but then reinfiltrates into the groundwater system at a different part of the lake bed (Ojiambo et al., 2001; Ojiambo et al., 2003; Weitz and Demlie, 2014, 2015; Ndlovu and Demlie, 2016). 21\% 
of Lake Chad's inflows are estimated to recharge the surrounding unconfined shallow aquifer (Isiorho et al., 1996; Edmunds et al., 1999). However, climate forcing and abstractions have caused the surface area of the lake to shrink to less than $10 \%$ of its extent in the $1960 \mathrm{~s}$ (Mahmood and Jia 2019), leading to declines in regional groundwater resources (Leblanc et al. 2007).

There are 726 reservoirs in Africa, with a storage approximately equal to 3\% of the continent's lake storage (Lehner et al. 2011) and there are many more either planned or under construction (Zarfl et al. 2014). Existing reservoir storage is mostly concentrated in Southern Africa, although some of the largest reservoirs are along the Nile (High Aswan dam) and Volta (Akosombo dam) rivers as well as the Zambezi (Kariba dam). In dry countries such as Tunisia and Egypt, stable isotopes show reservoir storage is recharging local aquifers and mixing with groundwater recharged thousands of years ago (Aly et al., 1993; Dassi et al., 2005). Recently, (Abdelmohsen et al. 2019) used stable isotopes, borehole observations and observations from the GRACE satellite mission to find that the High Aswan Dam is influencing groundwater stores up to $280 \mathrm{~km}$ away. They suggest the reservoir and the deep Nubian Sandstone Aquifer System are connected to one another through highly fractured and karstified bedrock, with the reservoir being a consistent source of groundwater recharge in both wet and dry periods. In contrast, groundwater recharge from the Bamendjin dam in tropical and mountainous north western Cameroon is restricted to within $100 \mathrm{~m}$ (Wirmvem et al. 2015).

\section{Seasonal}

Seasonal wetlands often exist in climates and landscapes that prohibit rapid infiltration or lead to groundwater exfiltration (Winter et al. 1998). In a global review of flood plain and headwater wetlands, Bullock and Acreman, (2003) struggled to conclude whether seasonal wetlands enhanced groundwater recharge. Of their 69 references, only six discussed increases in recharge due to wetland conditions, whereas nine highlighted reductions in recharge. A further 32 simply stated that recharge takes places.

Seasonal inundation of some of Africa's large floodplains and inland deltas creates periodic opportunities for extensive groundwater recharge. During seasonal flooding of the Okavango delta in Botswana, the inundated surface area of the flood plain increases from $5,000 \mathrm{~km}^{2}$ to up to $12,000 \mathrm{~km}^{2}$. As the alluvial fan primarily consists of highly permeable sands, the groundwater table can rise from a depth $3-5 \mathrm{~m}$ to the surface within a few days. Infiltration accounts for $90 \%$ of losses from the delta of which $80 \%$ drain laterally to the surrounding drylands (Ramberg et al., 2006; Wolski et al., 2006). On the other hand, recharge rates under the seasonally inundated Hadejia-Nguru floodplain in northern Nigeria, are less than $1 \mathrm{~mm} /$ year, as extensive clay cover prevents infiltration (Carter and Alkali, 1996; Edmunds et al., 1999; Goes, 1999). Recharge to the regional aquifer is instead largely attributed to transmission losses directly from the Komadugu river running through the wetland, which equates to $160-260$ million $\mathrm{m}^{3}$ of aquifer recharge per year or $30 \%$ to $40 \%$ of the rivers total discharge (Genthon et al. 2015). Therefore, highlighting both streambed transmission losses and floodplain inundation as mechanisms through which seasonally high river flows can lead to groundwater recharge and that floodplain inundation further relies upon favourable soil conditions for recharge to occur. 
Headwater wetland systems often occur in topographic depressions where most of the year's annual precipitation falls in a short wet season, leading to seasonal inundation. Names used to describe these wetland systems vary regionally and include, Dambos, Bolis, Bas-fonds, Mbuga or Vleis, though they are all frequently associated to crystalline basement geology (Faulkner and Lambert 1991; von der Heyden 2004; Séguis et al. 2011; Wright 1992). These wetlands are typically fed by groundwater recharged upslope as well as direct rainfall and saturation excess runoff and evapotranspiration are the dominant wetland outflows (Faulkner and Lambert 1991; Giertz and Diekkrüger 2003; McCartney 2000; Wright 1992). Infiltration below the wetland is frequently impeded by poorly draining clays which are responsible for the waterlogged conditions (McCartney et al., 1998; Séguis et al., 2011; von der Heyden, 2004). Groundwater fed wetlands can also occur along riparian channels as is the case in the Nyabisheki catchment of south western Uganda (Howard and Karundu 1992). These wetlands can extend up to several kilometres away from the stream channel and are characterized by phreatophyte plants which are capable of transpiring water at the full rate of potential evapotranspiration. Here evaporation and transpiration from the wetlands act as a direct loss to the aquifer system (Howard and Karundu 1992).

\section{Ephemeral}

In extremely dry landscapes such as the Sahara Desert, intense rainfall events are important drivers for focused recharge through flash flooding (Sultan et al. 2000) and the formation of ephemeral water bodies (Lehner and Döll 2004). In Northern Africa, the term Wadi refers to a dry riverbed which only receives flow sporadically or perhaps seasonally with similar dry river valleys also being characteristic of basins in southern Africa (Benito et al., 2010; Walker et al., 2019). These riverbeds are usually underlain by an alluvial aquifer system which gets recharged through riverbed transmission losses during heavy rainfall events (Tantawi et al., 1998; Sultan et al., 2000, 2007; Gheith and Sultan, 2002). In a wadi system of Egypt's Eastern Desert, Gheith and Sultan, (2002) estimate that transmission losses from a flooding event in the Red Sea Hills ranged from $21 \%$ to $31 \%$ of the precipitated volume. With similar rainfall events occurring once every 40 months. Annual flood waves through the Kuiseb River, Namibia, recharge the alluvial aquifer in the lower reaches of river as it crosses the Namib Desert (Benito et al. 2010; Morin et al. 2009). Stable isotope signatures of groundwater within alluvial aquifers of arid environments frequently show signs of fractionation as recharging water is affected by evaporation prior to infiltration (Tantawi et al., 1998; Abdalla, 2009). In endoreic arid basins, surface water can also accumulate in salt pans which typically occupy topographic depressions (Lehner and Döll 2004). (De Vries et al., 2000) use chloride profiles to show that in the eastern fringes of the Kalahari Desert, recharge is enhanced under these pans, with estimated annual rates of $50 \mathrm{~mm}$ in comparison to $7 \mathrm{~mm}$ for the surrounding landscape.

\section{S1.2.2 Mountains System Recharge}

The most well-known mountain ranges in Africa include the Atlas Mountains and Red Sea hills in Northern Africa, the Drakensberg Mountains and Table Mountain Group of South Africa, as well as the East Africa and Ethiopian rift systems. Other prominent mountain ranges can be found along the Nigeria-Cameroon border, Madagascar and across the Sahara (Smethurst 2000). These mountain blocks can be dominant sources of groundwater recharge to adjacent basin aquifers (Markovich et al., 2019; Meixner et al., 2016). We discuss the two 
components of groundwater recharge to basin aquifers proposed by Markovich et al. (2019), Surface Mountain Front Recharge and Mountain Block Recharge.

Surface Mountain Front Recharge is the infiltration from mountain-sourced perennial or ephemeral streams, through the basin fill at the mountain front, once streams have exited the mountain block (Markovich et al. 2019). Markovich et al. (2019) define the mountain front as the intersection between the land surface and the line of contact between mountain bedrock and basin fill. Though definitions can also encompass information about vegetation, soils, bedrock faulting and may refer to the mountain front as a transition zone instead of as a line or point (Wilson and Guan 2004). Bouimouass et al. (2020) used water table fluctuations and environmental tracers to investigate the effects of agricultural management on mountain front recharge in the High Atlas Mountains of central Morocco. They found that irrigation practices are altering the dominant recharge processes along the mountain front, though mountain front stream losses are still significant in snowmelt or flooding periods.

Mountain Block Recharge is the groundwater flow from the mountain block to the adjacent lowland aquifer, which can either occur diffusely across the entire mountain front, or in focused locations of high geologic permeability (Markovich et al. 2019). Researchers often use stable isotopes to determine the elevation at which precipitation recharged the groundwater system and hence identify groundwater recharged in the mountain block (Jasechko 2019). Combining this with groundwater age information can help understand the degree of mixing between younger and older groundwaters, but they don't give explicit information about the location of infiltration or how groundwater travels to the basin aquifer (Bouchaou et al. 2008; Boukhari et al. 2015; Diamond and Harris 2000). Therefore many of these findings are highly speculative (Markovich et al. 2019). Kebede et al. (2008) used stable isotopes and groundwater ages from carbon dating to investigate groundwater flow along two transects in the Ethiopian Rift. They find that geological faults can acts as both barriers and conduits for Mountain Block Recharge to the basin aquifer, suggesting that older isotopically depleted groundwater in the basin indicates faults acting as conduits for recharge. Mechal et al. (2016) later explored Mountain Block Recharge in Ethiopian Rift by coupling a semi-distributed soil moisture balance model with a groundwater model. They found that groundwater models which explicitly represented faults as both barriers and conduits for Mountain Block Recharge had improved model performance when compared to hydraulic heads at 72 observations wells. Furthermore, they found that an estimated $25 \%$ of recharge in the Gidabo Basin infiltrates to deeper groundwater flows that contribute to Mountain Block Recharge, with the remainder draining to streams.

\section{S1.3 Landcover/use}

Tree cover, shrubland and bare soils are the three most dominant landcovers across Africa (Tsendbazar et al., 2017). Desert regions such as the Sahara, the Namib and the horn of Africa are unsurprisingly dominated by bare soils and sparse vegetation. In contrast dense rainforest can be found in central equatorial regions of the continent and tropical woodland spreading into West and South Eastern Africa (Hansen et al., 2013; Mayes et al., 2015; Tsendbazar et al., 2017) and shorter shrub, grass or crop cover is distributed across the Sahel and much of Eastern and Southern Africa (Tsendbazar et al., 2017). Urban settings account for less than $0.01 \%$ of the African landscape and are currently expanding at rates slower than the rest of the world (van Vliet 2019; Zhou et al. 2015). 
1673 Tall vegetation landcovers, such as dense rainforest, open forests and woodlands cover $\sim 26 \%$ of Africa's land surface (Mayaux et al. 2004). Trees interact with the water cycle by increasing transpiration and interception and reducing evaporation (Gordon et al., 1992; Fan et al., 2013; Schlesinger and Jasechko, 2014; Goodet al., 2015; Zhang et al., 2016). Atmospheric losses due to transpiration dominate across the African continent. On average $49 \%, 21 \%$ and $7 \%$ of precipitation returns to the atmosphere via transpiration, bare soil evaporation and interception, respectively (Zhang et al. 2016). Once rainfall has entered the soil zone, vegetation roots can increase the permeability of soils and infiltration (Burgess et al. 2001). Deep rooting systems increase the capacity of root-zone moisture storage (Nijzink et al. 2016) and access to deeper groundwater (Barbeta and Peñuelas 2017), which leads to the bulk of continental transpiration being associated to tropical forests (Gordon et al., 1992; Good et al., 2015). However, increased canopy cover and shading lead to modest soil and surface water evaporation rates (Good et al., 2015) and moderately enhanced interception (Zhang et al. 2016). Hence, transpiration dominates the evapotranspiration flux in forested environments (Schlesinger and Jasechko 2014).

Globally, (Kim and Jackson 2012) show that woodlands have some of the lowest conversion rates of water input (precipitation + irrigation) to recharge, at just $6 \%$. This is also confirmed in catchment scale studies, which frequently find lower recharge rates in forested parts of the catchment (Gebreyohannes et al. 2013; Houston 1982; Howard and Karundu 1992). Soil moisture balance modelling estimates the mean annual recharge rate for a Zambian catchment to be $281 \mathrm{~mm} /$ year, though under open forest cover recharge estimations fell to $80 \mathrm{~mm} /$ year (Houston 1982). In the Ethiopian Rift, Gebreyohannes et al. (2013) estimate mean groundwater recharge under forest cover to be $5 \mathrm{~mm} /$ year whilst under agriculture and bare soils they find mean estimates of $86 \mathrm{~mm} /$ year and $64 \mathrm{~mm} /$ year respectively. Furthermore, the presence of woodland or forest can restrict groundwater recharge to years of particularly high rainfall, even when recharge in grassed, cropped or unvegetated parts of the catchment occurs annually and may exceed 200 mm/year (Houston 1982; Howard and Karundu 1992). Deforestation and the removal of tree cover can enhance groundwater recharge rates by reducing evapotranspiration (Taylor and Howard 1996; Været et al. 2009). In Uganda, (Taylor and Howard 1996) find that deforestation for agricultural expansion has led to an increase in recharge rates from $110 \mathrm{~mm} /$ year to $240 \mathrm{~mm} /$ year. While in South Africa, pine tree cover was removed to promote groundwater recharge and discharge to Lake St Lucia (Været et al. 2009).

Most of the continents' losses from interception evaporation occur in the densely forested regions of Central Africa (Miralles et al. 2010; Zhang et al. 2016; Zheng et al. 2017). In these densely forested regions, the evaporation flux of intercepted rainfall can approach rates of $300 \mathrm{~mm} /$ year and exceed $10 \%$ of the precipitation input. Furthermore, canopy storage in these regions is largely continuous, unlike in areas with deciduous vegetation where it can vary (Kahiu and Hanan 2018). We could not find any studies directly discussing the relationship between rainfall interception and groundwater recharge in Africa or elsewhere. However, it seems reasonable to assume that by limiting the amount of rainfall that reaches the land surface, interception is consequently reducing the amount of groundwater recharge which can occur. 
1717 Shorter landcover types such as grasslands, shrublands and agriculture, are largely distributed throughout the Sahel and Southern and Eastern Africa (Tsendbazar et al. 2017), each accounting for an estimated $15.4 \%, 13.4 \%$ and $11.6 \%$ of the African land area respectively (Mayaux et al. 2004; Xiong et al. 2017). Managed agricultural land also extends into Northern Africa, along the banks of the river Nile and along the coastline (Xiong et al. 2017). Kim and Jackson (2012) show that globally, grasslands and croplands are more efficient in converting a water input (precipitation + irrigation) to recharge than woodlands, with rainfallrecharge rates of $8 \%, 11 \%$ and $6 \%$, respectively. However, they also found shrublands heathlands and savannas only convert $5 \%$ of rainfall to recharge.

In semi-arid West Africa, Ilstedt et al., (2016) discuss the trade-off between the infiltration promotion properties of trees and their interception and transpiration functions. In the Kalahari Desert, dense bush and tree savannah is believed to transpire much of the annual rainfall during the long dry season, leading to very little recharge (De Vries et al., 2000; Sibanda et al., 2009). Especially as trees in these drier landscapes can develop deep root systems allowing them to access the water table (Sibanda et al., 2009; Addai et al., 2016). This agrees with chloride profiles in Senegal, which suggest that as vegetation density increases, annual rates of groundwater recharge decline (Edmunds and Gaye 1994). However, Bargués Tobella et al., (2014) find that trees in dryland settings can increase soil infiltration and preferential flow.

Kim and Jackson (2012) show croplands throughout the world are more efficient in converting rainfall to recharge than grasslands, woodlands shrublands and savannas. Although, the impact of land clearing on recharge varies across climate zones and indigenous vegetation types. In an inter-mountain basin in tropical Cameroon, Wirmvem et al. (2015) believe that deforestation for agriculture has enhanced rapid infiltration mechanisms by increasing the number of openings in the soil. In contrast, extensive land clearing of natural savanna for agriculture in semi-arid South West Niger has led to soil crusting on slopes, which in turn has led to increases in seasonal runoff and drainage density (Leduc et al., 2001; Leblanc et al., 2008; Favreau et al., 2009). Increased seasonal ponding has since led to the continuous rising of the water table between 1963 and 2007, despite a monsoon rainfall deficit from 1970 to 1998 , as pre and post clearing recharge rates for the area are $2 \mathrm{~mm} /$ year and $25 \mathrm{~mm} /$ year, respectively.

Adjacent to many of Africa's largest lakes and rivers, such as lake Chad and the rivers Nile, Senegal, Niger and Orange, agricultural land is being equipped for irrigation (Siebert et al. 2015). Excess irrigation water can infiltrate into the soil and percolate to the aquifer, increasing groundwater recharge rates. This type of recharge can be particularly important in semi-arid and arid environments which have very little natural water input from precipitation (Kim and Jackson 2012). However, groundwater fed irrigation often leads to a net decline in aquifer storage (Guendouz et al., 2006; Bouchaou et al., 2008; Tarki et al., 2012; Wada et al., 2012), unlike surface water fed irrigation which enhances natural recharge with water transferred from streams (Awad et al. 1995; Bouimouass et al. 2020; Scanlon et al. 2007). As irrigation technologies become more efficient, recharge via irrigation excesses will decline

1758 (Scanlon et al. 2007), which could also help reduce the salinization of groundwater by excess 
1761 Approximately 33\% of Africa's land surface, mostly in North Africa's Sahara Desert, is classified as bare soil (Mayaux et al. 2004), with additional unvegetated landscapes along the Ethiopian, Somalian and Namibian coastlines. These desert landscapes mostly consist of stony pavements and desert dunes (also known as Ergs), as there is insufficient water to support vegetation (Crouvi et al. 2010; Fujioka and Chappell 2011; Kocurek 1988). Diffuse groundwater recharge is not actively occurring in many desert landscapes as precipitation rates are extremely low (Guendouz et al. 2006; Sturchio et al. 2004), but in less water stressed environments, bare soils can promote groundwater recharge as the transpiration fluxes are negligible (Gebreyohannes et al. 2013; Stone and Edmunds 2012).

\section{Urban settings}

1771

1772

1773

1774

1775

1776

1777

1778

1779

1780

1781

1782

1783

1784

1785

1786

1787

1788

1789

1790

1791

1792

1793

1794

1795

1796

1797

1798

1799

1800

$40 \%$ of the Sub-Saharan population is living in urban areas (World Bank 2019) and many cities depend on groundwater for domestic water supply (Adelana et al. 2008). Understanding groundwater recharge to urban aquifers is therefore important when assessing groundwater availability for a large proportion of the African population.

The typical perception of urbanisation is that it reduces the permeable surface area and therefore reduces groundwater recharge, yet recharge rates in urban areas can be as high as or even higher than nearby rural areas (Lerner 2002; Sharp 2010). Large landscape alterations through urbanization can dampen and modify existing recharge mechanisms as well as introduce new recharge mechanisms. Localised recharge along the edges of roads, pavements and buildings can occur in municipal areas with very little drainage infrastructure (Lerner 2002; Sharp 2010). Leaking wastewater from on-site sanitation can be a source of groundwater recharge and pollution, degrading urban groundwater quality (Diouf 2012; Foster, Morris, and Chilton 1999; Guendouz et al. 2006; Lapworth et al. 2017). And if piped water supply is available, leakage from pressurized distribution networks can recharge the urban aquifer.

\section{S1.4 Soils/geology}

\section{Soil texture (grain size)}

Soils with larger sand fractions are more permeable and support higher recharge rates than finer clay soils. In a global scale meta-analysis of recharge estimates, Kim and Jackson (2012) show that on average sandy soils are 50\% more efficient in converting water input into groundwater recharge. Similar results are found at regional and catchment scales in Senegal, Sudan and Zimbabwe, whereby higher recharge rates are estimated in areas where the sand fraction is a more dominant component of the soil (Abdalla 2009; Butterworth et al. 1999; Edmunds and Gaye 1994). In soils with high clay content, not only is the vertical percolation of water through the soil profile restricted (Attandoh et al. 2013; Edmunds et al. 1992), but soil moisture is more exposed to evapotranspiration fluxes ( Mensah et al, 2014; Yidana and Koffie, 2014; Kotchoni et al., 2018). Often basic soil information such as soil texture is used to characterize the permeability of soils (Saxton et al., 1986; Wösten et al., 2001), though Gutmann and Small (2007) question the ability of soil textures alone for determining soil permeability. 


\section{Preferential flow}

Soil texture alone fails to recognise structural soil properties which enable infiltration via preferential flow paths which bypass the soil matrix (Beven and Germann 1982). Macropores in the soil structure allow water to infiltrate preferentially through the subsurface, bypassing vegetation rooting zones and reducing the influence of evapotranspiration. In most soils, the primary influence to soil structure is biological activity through the formation of biopores and soil aggregation (Bargués Tobella et al. 2014; Beven and Germann 1982; Flury et al. 1994), though several abiotic processes are also influential (Oades 1993). The contribution of preferential flow to groundwater recharge can be estimated by comparing from saturated and unsaturated zone analysis (Cuthbert and Tindimugaya 2010; Demlie 2015; de Vries and Gieske 1990). Preferential flow path recharge mechanisms are important in contrasting environmental settings. In the Botswanan Kalahari Desert, semi-arid Tanzania and the tropical highlands of Ethiopia, preferential flow can account for as much as $24 \%, 60 \%$ and $36 \%$ of total recharge estimates, respectively (Demlie et al. 2007; Nkotagu 1996; de Vries and Gieske 1990).

Preferential flow paths may partly explain why Mazor (1982) identified more active recharge in the Kalahari when dating groundwaters using tritium and carbon dating, despite the previous perception that it was negligible. In South Africa's Karoo basin, Van Tonder and Kirchner (1990) found that groundwater levels rose following a flood event, despite neutron probe measurements showing very little soil matrix flow very little soil matrix flow. Hence implying most of the recharge occurs via preferential flow paths. In Ethiopia, Demlie et al. (2007) suggest that as soils become deeper, the importance of preferential flow paths for enabling recharge increases.

Rock fracturing can also create pathways through which water can rapidly pass through the subsurface and recharge aquifers (Nkotagu, 1996; Xu and Beekman, 2003; Adams et al., 2004; Kebede et al., 2005; Azagegn et al., 2015). Extensive faulting and fracturing in the catchment of Lake Nyos, in the highland tropical north west of Cameroon, allows for approximately $30 \%$ of rainfall to be converted into recharge, with an estimated annual recharge rate of $941 \mathrm{~mm} /$ year (Kamtchueng et al. 2015). In hard rock terrains of Southern Africa, van Wyk et al., (2012) suggest that a network of vertical and sub-vertical joints and fractures reaching depths of $45 \mathrm{~m}$, transports infiltrating rainfall to the water table within hours.

Another relevant geological unit related to preferential flows is karst, which can create significant subsurface heterogeneity of flowpaths. Vertical conduits in the karstified rock enable rapid recharge mechanisms whereby water does not occupy the soil zone for long times (Chemseddine et al., 2015), exposure to evapotranspiration is minimised and very little runoff is generated (Ayadi et al. 2018; Farid et al. 2014; Holland and Witthüser 2009; Leketa et al. 2019). Karst refers to a distinctive geological landform in which water is drained through subsurface channel and cavity features formed through the dissolution of soluble rocks such as carbonates and evaporites (Bakalowicz 2005; Ford and Williams 2007). This karstification leads to a highly heterogenous subsurface with extreme variations in hydraulic conductivity and storage due to the previously mentioned weathering processes (Ford and Williams 2007). Regional scale hydrological modelling of carbonate regions in Northern 
Africa and Europe shows that by not characterizing the sub-surface heterogeneity of karst systems in global models, current estimates of annual recharge from global models could be grossly underestimating recharge in these landscapes (Hartmann et al. 2017).

\section{Bedrock outcrops}

In dry landscapes, bedrock outcrops are important for enhancing groundwater recharge because of rock fractures. In the Kalahari Desert, recharge under the bedrock outcrops can be up to six times larger than neighbouring areas with greater soil depths, with estimated rates reaching 75mm/year (Brunner et al. 2004; Mazor 1982; Wanke et al. 2008). Soils can become thinner with increasing elevation, which in turn can lead to more effective conversion of rainfall to recharge and higher annual rates, as Van Tonder and Kirchner (1990) found in two Karoo aquifers in South Africa. Isolated rock formations called inselbergs are widely distributed across crystalline continental shields and have been formed by erosion of the surrounding landscape (Burke 2003). Groundwater responses under inselbergs are generally much faster than in the broader surroundings, as infiltration through the fractured rock is easier and less exposed to evaporation (Brunner et al. 2004; Butterworth et al. 1999).

\section{Soil perturbation}

Crusting, cementation, weathering, tillage and compaction are soil perturbations at the surface that can have significant impact on recharge rates.

(i) In arid and semi-arid regions soil crusting can prevent precipitation from infiltrating into the soil where it has fallen (Wakindiki and Ben-Hur 2002), but often leads to runoff run-on process which cause surface water accumulation and focussed recharge (Favreau et al. 2009; Jacks and Traoré 2014). Surface crusting occurs because of the disaggregation of soil particles at the surface via the impact of raindrops (Agassi et al., 1981; Thierfelder et al., 2013; Jacks and Traoré, 2014) or immersion in water (Nciizah and Wakindiki 2015).

(ii) The cementation of soil layers by secondary minerals (minerals that occur due to the weathering of primary minerals) such as silica and calcium is common in dry landscapes with large evaporation fluxes (Francis et al. 2007). Collectively referred to as duricrusts (Nash et al., 1994; Nash and Shaw, 1998), these cemented layers reduce the permeability of the soil and promote water logging (Francis et al. 2007). However, preferential flow paths can bypass these layers to permit groundwater recharge (De Vries et al., 2000; Mazor, 1982; Van Tonder \& Kirchner, 1990; Xu \& Beekman, 2003).

(iii) Deeply weathered soils known as laterite are found extensively across tropical regions of Africa (Bonsor et al., 2014) and the world (FAO, 2001; McFarlane, 1970). The weathering process creates distinct soil horizons which are responsible for extremely non-linear variations in soil permeability with depth (Bonsor et al. 2014). Clays at the base of the laterite can inhibit recharge to the underlying bedrock aquifer (Bonsor et al. 2014), while tubular voids in the upper horizons can allow fast recharge to the overlying regolith aquifer (Bromley et al. 1997; Cuthbert and Tindimugaya 2010) as wells as rapid shallow sub-surface flows to the stream (Bonsor et al. 2014). When the upper soil horizon does not contain large voids, low soil permeability can cause a runoff run-on process leading to focussed recharge (Rueedi et al., 2005). 
(iv) Tillage is the practice of mechanically loosening soil within the crop rooting zone in preparation for agricultural activities. The current understanding of how tilling effects soil infiltration rates is still rather unclear as findings from studies can be inconsistent (Strudley, Green, and Ascough 2008), with evidence for both increases (Mrabet, 2002; Spaan et al., 2005) and decreases (Lal, 1976; Osunbitan et al., 2005) in infiltration, depending upon the soil type (Thierfelder and Wall 2009), the equipment being used (Abu-Hamdeh 2004) and tilling depth (Hussein et al., 2019).

(iv) Soil degradation caused by soil compaction affects approximately $0.6 \%$ of Africa's land area (Oldeman et al., 2007) due to livestock and wildlife (du Toit et al., 2009; Howison et al., 2017) or human activity (Randrup, 1997; Hamza and Anderson, 2005; Umer et al., 2019). It reduces the infiltration capacity of the soil (Hamza and Anderson 2005; du Toit et al. 2009), thus reducing groundwater recharge and increasing runoff, especially in regions where infiltration excess is the dominant runoff mechanism (Alaoui et al. 2018).

\section{S1.5 Managed Aquifer Recharge}

Managed Aquifer Recharge refers to a range of methods used to intentionally increase groundwater recharge, which include, modifying the channel streambed, bank filtration, recharge wells, spreading water or reservoir releases (Dillon et al. 2019; Stefan and Ansems 2018). These methods can help maximise natural water storage, support groundwater dependent ecological systems and help manage groundwater quality and the aquifer (Stefan and Ansems 2018). Current capacity for Managed Aquifer Recharge is lower in Africa than in all other regions of the world and accounts for just $0.2 \%$ of groundwater use in Southern Africa (Dillon et al. 2019). Highlighting one possible opportunity for advancing groundwater security in Africa (Grönwall and Oduro-Kwarteng 2018). In a rural Ethiopian catchment, (Walraevens et al. 2015) find that hill slope runoff captured by trenches and infiltration ponds can contribute between $30 \%$ and $50 \%$ of recharge to the local aquifer, which supports community scale irrigation practices. Sand storage dams, which store stream flows in sediments accumulated behind the small dams, can capture water from flash flooding events and minimise storage losses by evaporation (Hut et al. 2008). Abiye et al., (2009) even suggest that Managed Aquifer Recharge could be a preferred discharge option for treated urban wastewater effluents in Addis Ababa, instead of returning flows to more polluted surface waters.

\section{S1.6 Interactions between controls}

Up to now we have largely looked at landscape properties and their control over recharge processes independently, in reality, groundwater recharge is a function of the interactions between these controls. Hence at the continental scale, we would typically expect to find some of the lowest recharge rates in areas with the most freely draining soils, as these regions also have the lowest precipitation volumes. By identifying patterns in the landscape, i.e. climate, topography, vegetation, soils and geology, we can begin to conceptualise recharge processes of different environmental settings found in Africa. We can find these patterns as landscapes are continuously co-evolving (Troch et al. 2013) via an array of physical and biological processes which effect the uplift and deformation of bedrock and the erosion, transportation and deposition of sediments (Dietrich and Perron 2006; Reinhardt et al. 2010). 
This co-evolution, explains why we typically expect to find certain landscapes throughout the continent, including rainforests, tropical woodlands and savannas and deserts.

We often regard climate as an external force driving the hydrological system, but it also controls the spatial and temporal patterns of landcover (Zhou et al., 2014; Hawinkel et al., 2016; Bouvet et al., 2018; Measho et al., 2019; Ndehedehe et al., 2019) and soils (Jenny 1941; Towett et al. 2015). Climate and vegetation patterns as well as soil properties are also strongly affected by local topography. In mountainous areas we see vegetation becoming shorter and less dense above the treeline, as temperatures decline and thinning soils make ground conditions less stable (Harsch et al., 2009; Egli and Poulenard, 2016). Increased precipitation and runoff due to orographic forcing as well as steeper slopes, promote more active erosion and sediment transport fluxes at elevation and therefore prevents the accumulation of soils (Acosta et al. 2015). In contrast, at lower elevations, vegetation can assist the accumulation of soils by reducing surface water erosion and promoting infiltration (Acosta et al. 2015; Descheemaeker et al. 2006; Descroix et al. 2009; Thompson et al. 2010). In water limited regions, vegetation density often increases in topographic depressions such as ephemeral streams, as accessibility to groundwater may be locally improved (Morin et al., 2009; Steward et al., 2012; Ndehedehe et al., 2019; Grodek et al., 2020).

\section{S1.7 Summary}

Summarizing our review, we believe that 15 of the 22 recharge controls identified have a clear positive (blue) or negative (red) relationship with recharge (Figure 1). Before integrating any of the recharge controls into our classification shown in the results section, they were screened against three criteria. Firstly, there needed to be a clear, well-founded and direct relationship between the recharge control and recharge. We do not include elevation as a control on groundwater recharge, although others have (Moeck et al. 2020), as we argue it only indirectly influences recharge through its relationship with climate, slope, landcover, soils and geological characteristics. Secondly, only controls which could be identified by global datasets were included. Finally, as our focus is on diffuse groundwater recharge, we exclude controls which were not found to directly effect this recharge mechanism.

\section{S2. Fuzzy clustering}

To delineate regions with similar recharge control indices we use the fuzzy c-means clustering algorithm (Bezdek 1981) implemented in Matlab as the function fcm. At first the membership of pixels to each of the units is randomly initialized. The algorithm starts by randomly assigning the membership of pixels to each of the units. It then continues to iteratively calculate the centroid of each unit, the membership of each pixel to each of the units and an objective function which we are trying to minimise. This continues until the difference between consecutive objective function scores falls below a user-specified threshold or until a maximum number of iterations (also specified by the user) has been reached. To prevent biasing the clustering process to the recharge control index with the largest range, we first standardized all indices between 0 and 1 . 
$\mathrm{c}_{\mathrm{j}}=\frac{\sum_{\mathrm{i}=1}^{\mathrm{D}} \mu_{\mathrm{i}, \mathrm{j}}^{\mathrm{m}} \mathrm{x}_{\mathrm{i}}}{\sum_{\mathrm{i}=1}^{\mathrm{D}} \mu_{\mathrm{i}, \mathrm{j}}^{\mathrm{m}}}$

1970

1971

$$
\mu_{\mathrm{i}, \mathrm{j}}=\frac{1}{\sum_{\mathrm{k}=1}^{\mathrm{N}}\left(\frac{\left\|\mathrm{x}_{\mathrm{i}}-\mathrm{c}_{\mathrm{j}}\right\|}{\left\|\mathrm{x}_{\mathrm{i}}-\mathrm{c}_{\mathrm{k}}\right\|}\right)^{\frac{2}{\mathrm{~m}-1}}}
$$

1972

1973

$\mathrm{OF}_{\mathrm{m}}=\sum_{\mathrm{i}=1}^{\mathrm{D}} \sum_{\mathrm{j}=1}^{\mathrm{N}} \mu_{\mathrm{i}, \mathrm{j}}^{\mathrm{m}}\left\|\mathrm{x}_{\mathrm{i}}-\mathrm{c}_{\mathrm{j}}\right\|^{2}$

where,

- $\mathrm{OF}$ is the clustering objective function.

- $\mathrm{m}$ is a fuzzy exponent parameter.

- $\mathrm{N}$ is the number of units specified.

- $\mathrm{D}$ is the number of data points.

- $\mathrm{x}_{\mathrm{i}}$ is the $\mathrm{i}^{\mathrm{th}}$ data point.

- $c_{j}$ is the centroid of the $j^{\text {th }}$ unit.

- $\mu_{i, j}$ is the membership of $x_{i}$ to the $j^{\text {th }}$ cluster. For a given data point, the sum of the membership values to each of the units is equal to one.

Algorithm parameters include the number units $(\mathrm{N})$ used to delineate similar regions as well as a fuzzy exponent parameter $(\mathrm{m})$, which determines the fuzziness of boundaries between units (Schwämmle and Jensen 2010). We tested different combinations of the number of units (1 to 40) and the fuzzy exponent (1.05 to 3 ) to observe how this effected the objective function of the clustering algorithm as well as the median membership of pixels to their primary unit of the realized classification. We specified 14 units and a fuzzy exponent of 1.25 , as this minimised the objective function to a level similar to classifications with much higher units, whilst still finding pixels with a high degree of membership to their primary unit.

As the initial centroids of each unit are randomly assigned before being iteratively manipulated towards their final positions, their final positions and hence the classification can vary with each initiation of the clustering algorithm. We therefore used a multistart framework (20 initialisations) to test the robustness of our results, using the Adjusted Rand Index (Hubert and Arabie 1985) to assess the similarity between each of the realized classifications. Scores of 0 indicate no similarity between two classification schemes, whereas a score of 1 implies that the two classification schemes are identical. 


\section{S3. Supporting results}

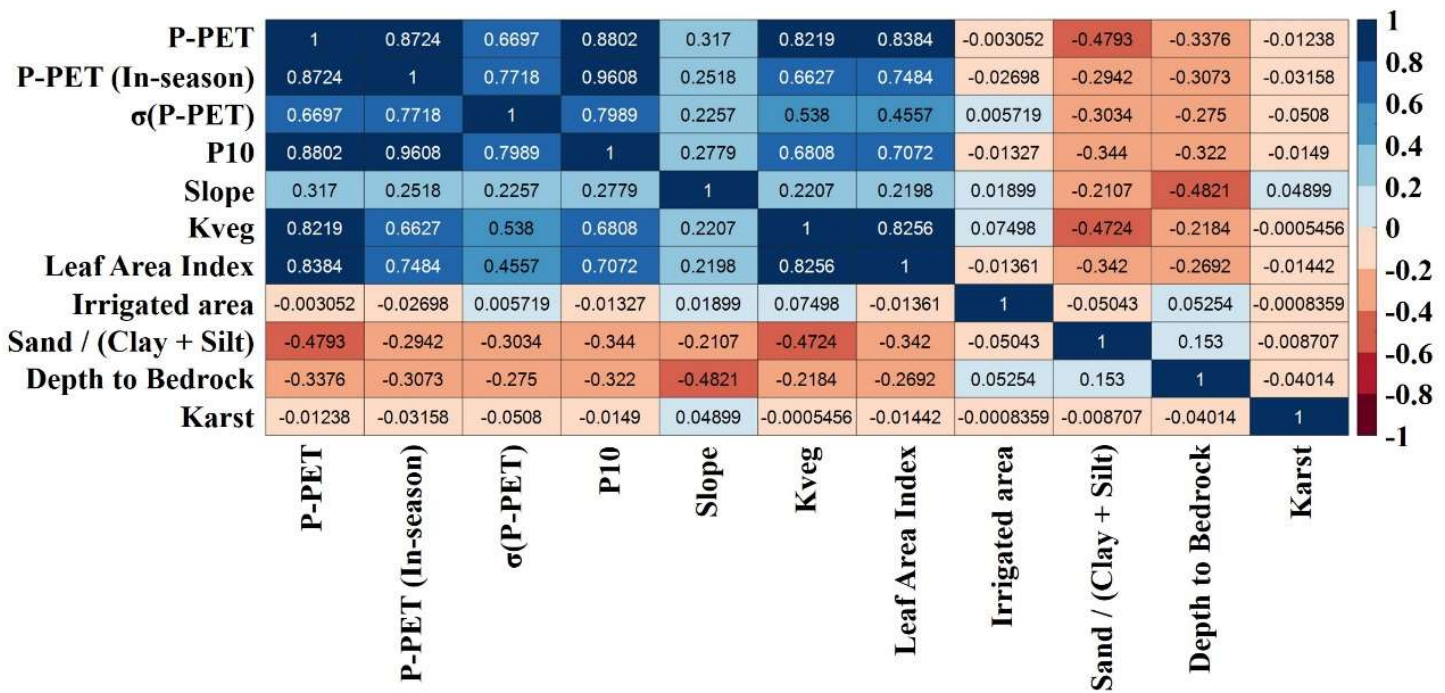

Figure 9. Pearson correlation coefficients between the different recharge control indices we used to develop our only.

2011
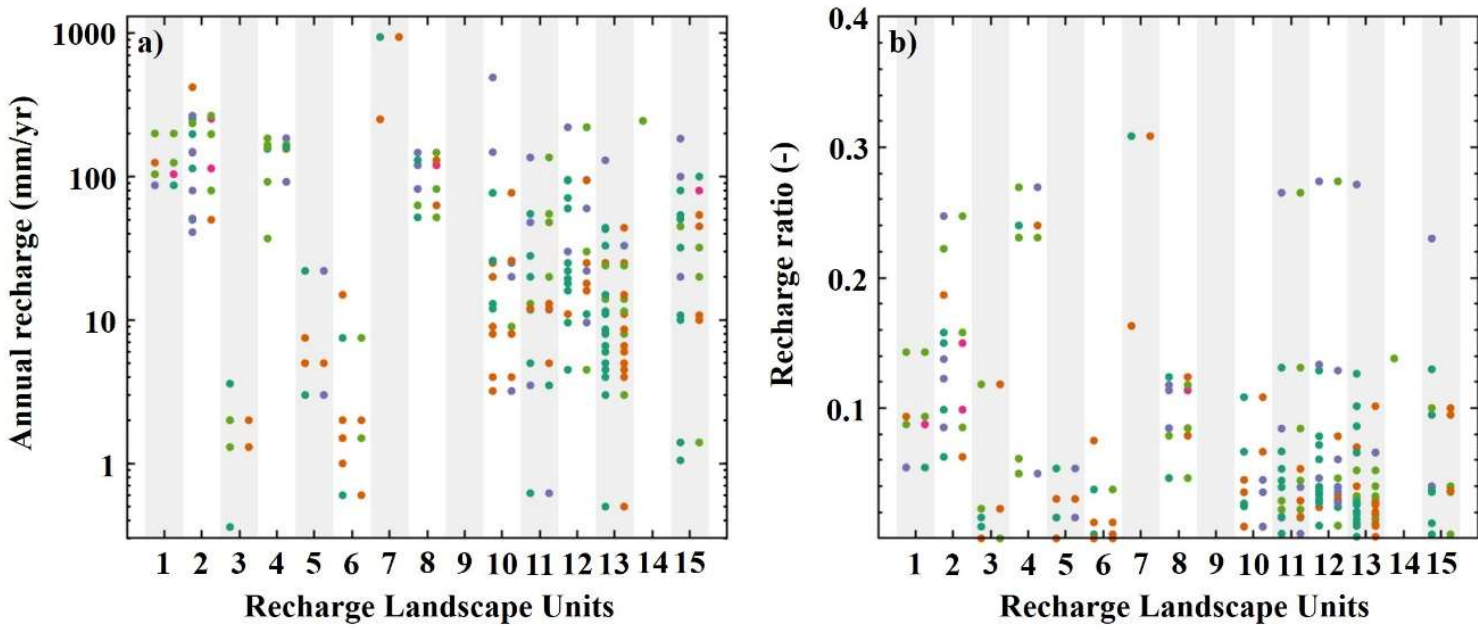

Chloride Mass Balance

Multiple Tracers

Water Table Fluctuation

Water Balance \& Soil Moisture Balance Models

Baseflow Separation

Figure 10. a) Local estimates of annual recharge and b) local estimates of recharge ratio. Estimates are organised according to the Recharge Landscape Unit they are located in, and colour coded according to estimation approach. Most data points are represented by two side-by-side markers reflecting the primary (left) and secondary (right) estimation method. Estimates 
From figure 2 we cannot see any clear separation of annual recharge or recharge ratio estimates according to the different estimation methods used. Therefore, we assume that the estimation method is not the primary reason for variability in annual recharge and recharge ratio estimates in within Recharge Landscape Units.
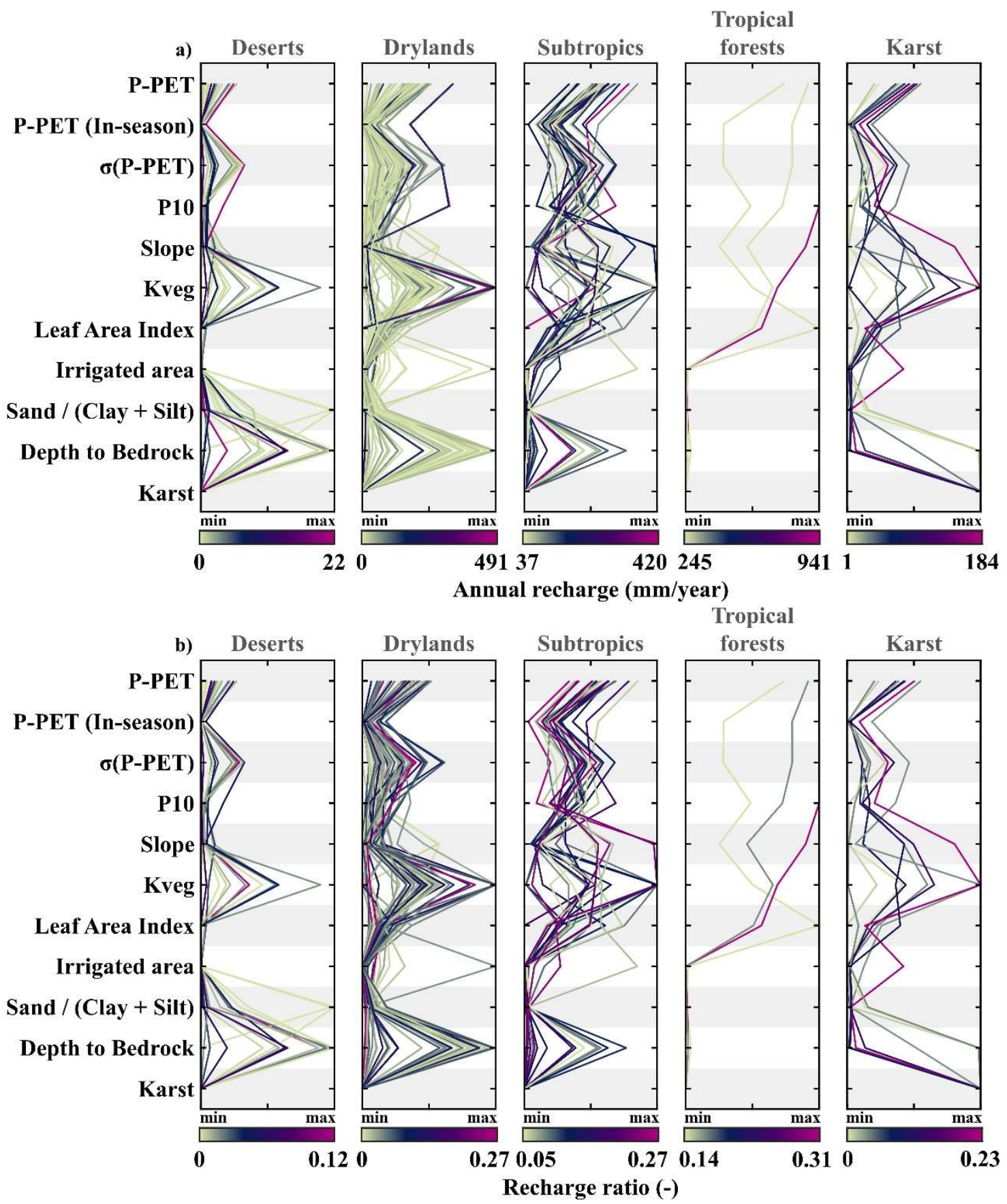

Figure 11. Parallel co-ordinate plot showing the scaled recharge control indices at each individual site organised into its corresponding Recharge Landscape. Indices at each site are scaled between 0 (minimum) and 1 (maximum) using the index values corresponding to our local estimate sites. Each line represents an individual site and colour coding reflects a) annual recharge and b) recharge ratio. The colour axis for each subplot is specific to the range of local annual recharge or recharge ratio estimates in that landscape. We separate out sites in karst settings to explore what causes recharge variation within these environments. 

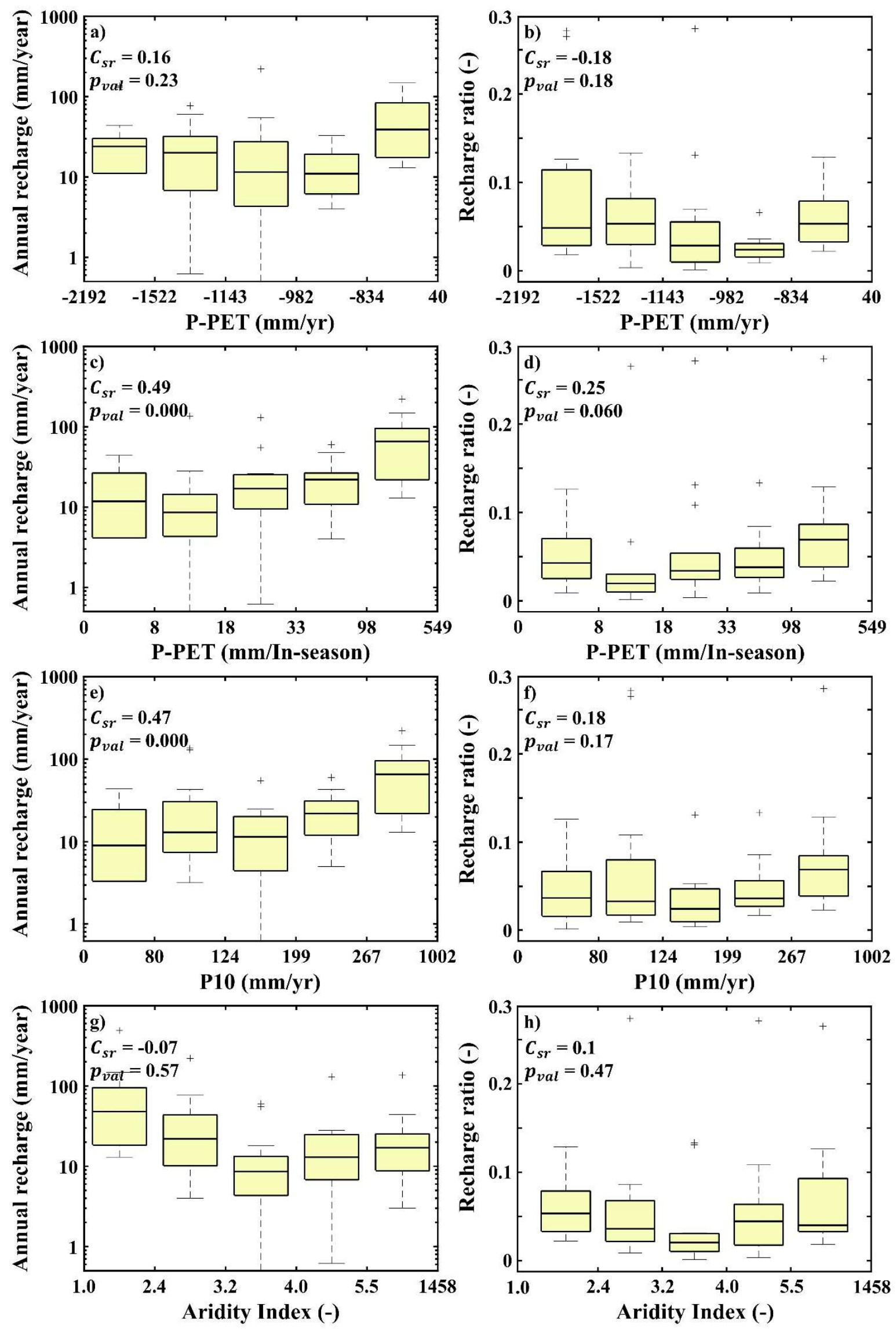

Figure 12. Boxplots showing how ground-based estimates of mean annual recharge vary according to (a) P-PET; (c) P-PET 
estimates of mean annual recharge ratios vary according to (b) P-PET; (d) P-PET in-season; (f) P10; (h) Aridity Index (i.e., $\mathrm{PET} / \mathrm{P})$ in Dryland Recharge Landscapes. Recharge signatures are binned according to percentiles (0-20; 20-40; 40-60; 60$80 ; 80-100)$ of the controlling variable. In the top left corner of each sub-plot, we show the spearman rank correlation and the
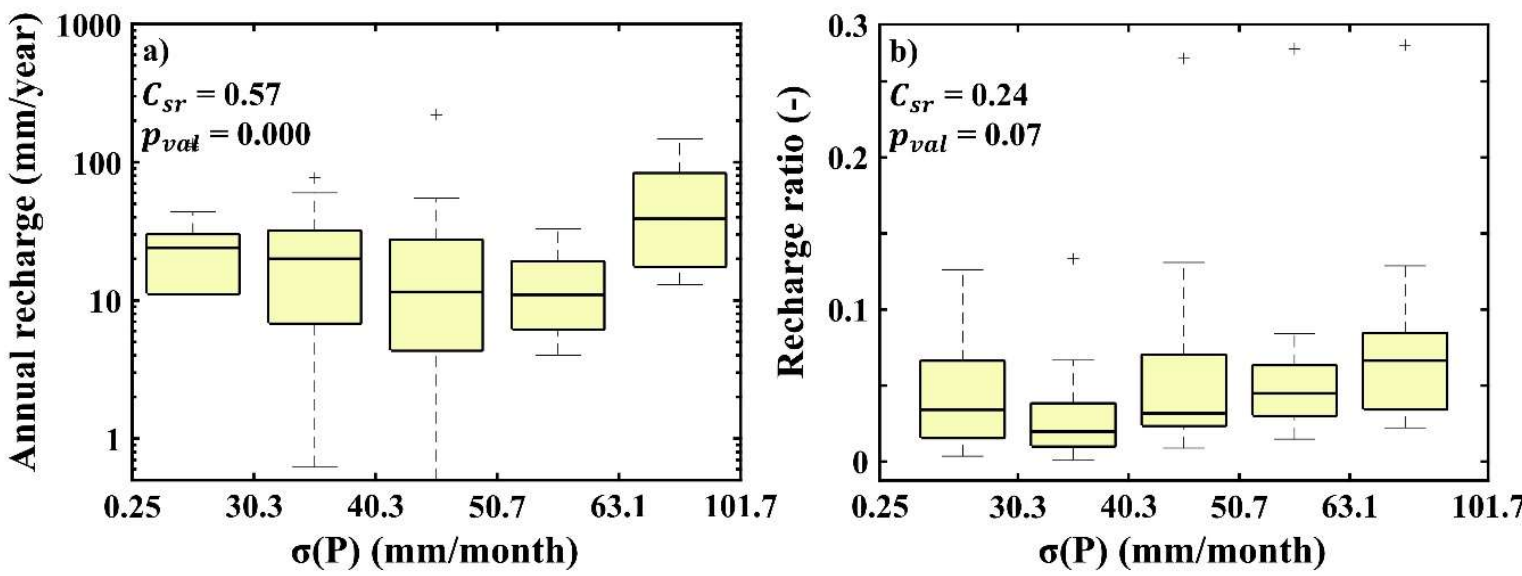

Figure 13. Boxplots showing how ground-based estimates of mean annual recharge (a) and recharge ratio (b) vary according to monthly variability of precipitation in Dryland Recharge Landscapes. Recharge signatures are binned according to percentiles $(0-20 ; 20-40 ; 40-60 ; 60-80 ; 80-100)$ of the controlling variable. In the top left corner of each sub-plot, we show the spearman rank correlation and the p-value for testing the hypothesis of no correlation. in Africa to the rest of the world

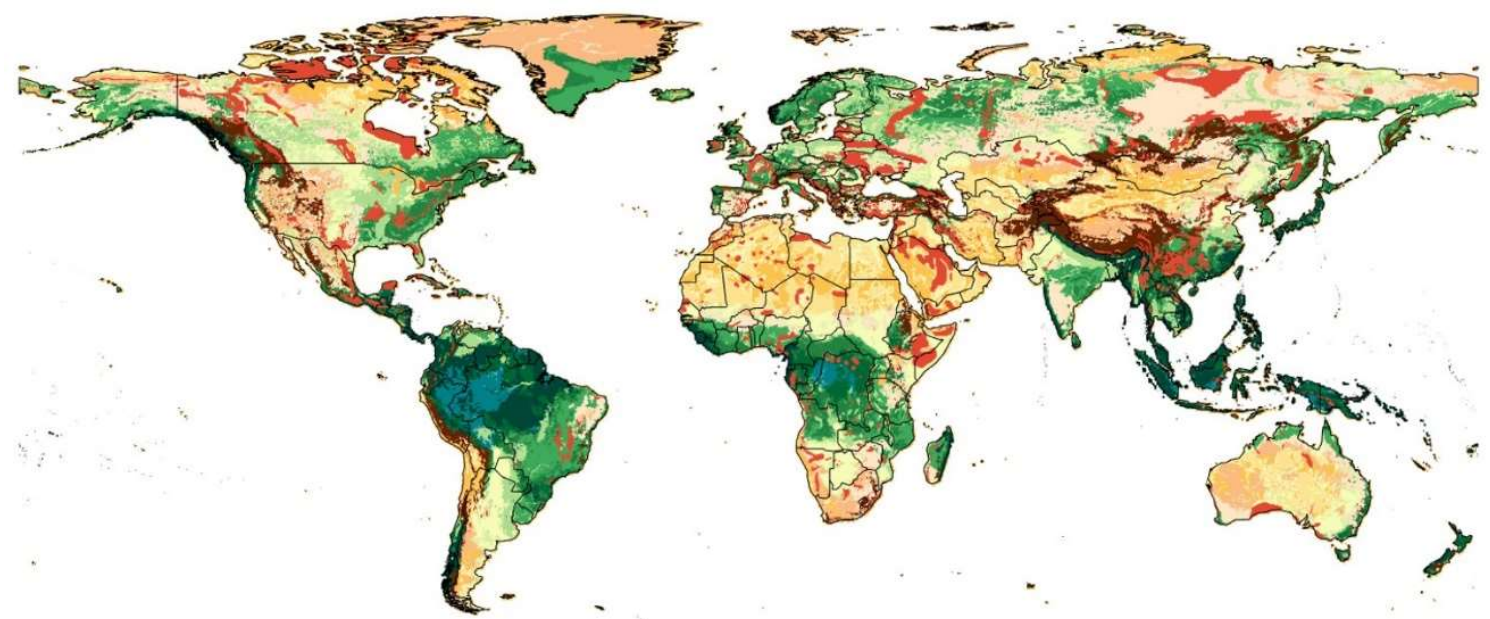

Figure 14. Transferal of Recharge Landscape Units to domains outside Africa using the random forest model and still 

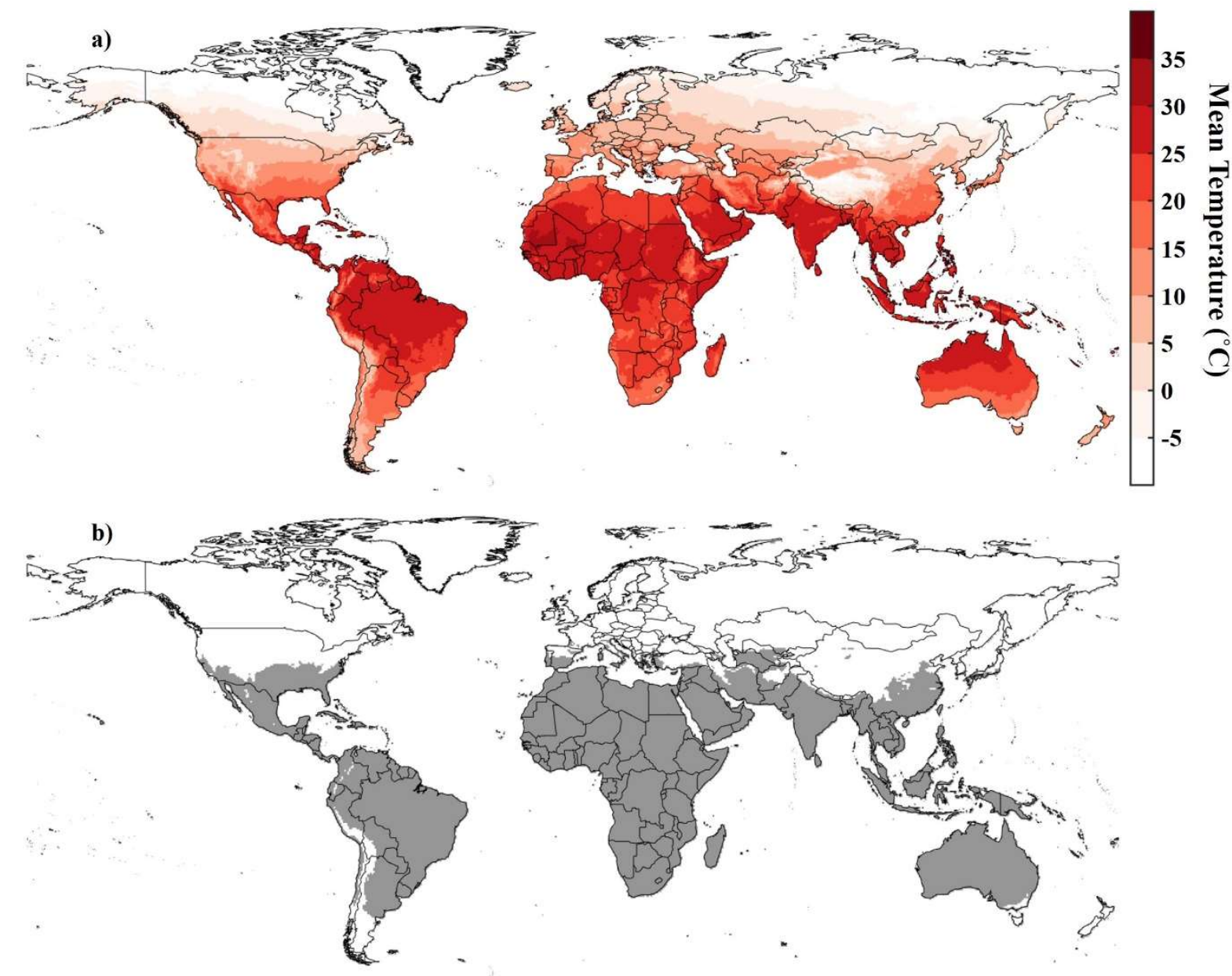

Figure 15. a) Mean temperature in degrees Celsius; b) Regions included in global classification of Recharge Landscape Units according to mean temperatures. Areas outside of Africa are excluded if the mean temperature is regarded as an outlier, whilst all pixels within Africa are included. We defined outliers as pixels where the temperature is below $Q_{1}-$ $(1.5 \times I Q R)$ or above below $Q_{3}+(1.5 \times I Q R)$. Where $Q_{1}$ is the $25^{\text {th }}$ percentile of mean temperatures within Africa, $Q_{3}$ is the $75^{\text {th }}$ percentile of mean temperatures within Africa and IQR is the inter-quartile range mean temperatures within Africa. We use a global gridded dataset of daily temperature provided by the Climate Prediction Center, NOAA 

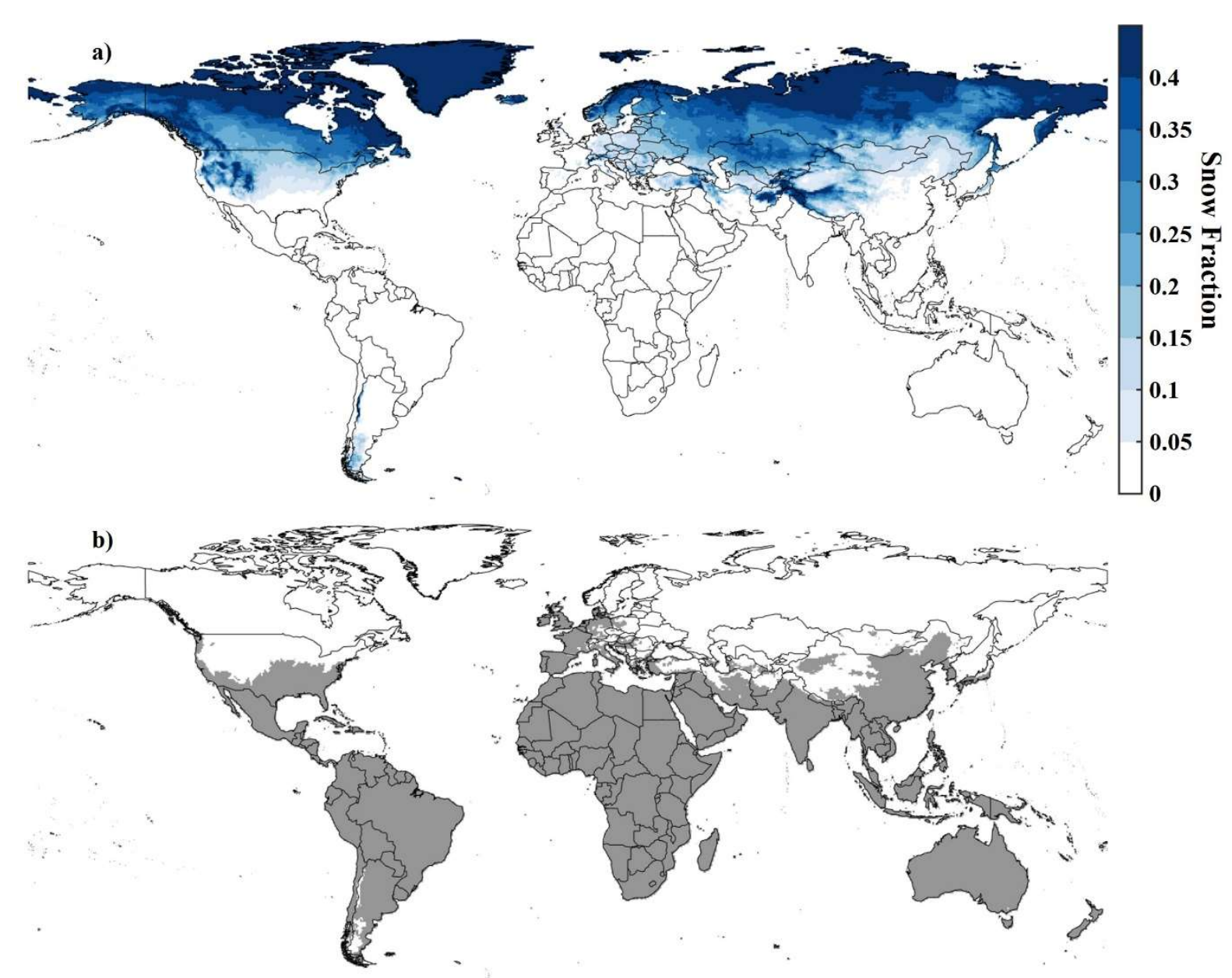

Figure 16. a) Snow fraction (Mean annual snowfall/Mean annual precipitation); b) Regions included in global classification of Recharge Landscape Units according to Snow fractions. Areas outside of Africa are excluded if the snow fraction is above 0.1 . The maximum snow fraction we find in Africa is 0.087 . We estimated snow fractions by using a simple temperature threshold. Precipitation on days with an average temperature below $1^{\circ} \mathrm{C}$ is regarded as entirely snowfall whereas it is entirely rainfall on days with an average temperature above $1^{\circ} \mathrm{C}$ (Berghuijs et al., 2014; Stein et al., 2020). We use a global gridded dataset of daily temperature provided by the Climate Prediction Center, NOAA (NOAA/OAR/ESRL PSD).

\section{S5. References}

Abdalla, Osman A. E. 2009. "Groundwater Recharge/discharge in Semi-Arid Regions Interpreted from Isotope and Chloride Concentrations in North White Nile Rift, Sudan." Hydrogeology Journal 17(3):679-92.

Abdelmohsen, Karem, Mohamed Sultan, Mohamed Ahmed, Himanshu Save, Baher Elkaliouby, Mustafa Emil, Eugene Yan, Abotalib Z. Abotalib, R. V. Krishnamurthy, and Karim Abdelmalik. 2019. "Response of Deep Aquifers to Climate Variability." Science of the Total Environment 677:530-44.

Abidela Hussein, Misbah, Habtamu Muche, Petra Schmitter, Prossie Nakawuka, Seifu A. Tilahun, Simon Langan, Jennie Barron, and Tammo S. Steenhuis. 2019. "Deep Tillage Improves Degraded Soils in the (Sub) Humid Ethiopian Highlands." Land 8(11):159.

Abiye, Tamiru Alemayehu, Hameed Sulieman, and Michael Ayalew. 2009. "Use of Treated Wastewater for Managed Aquifer Recharge in Highly Populated Urban Centers: A Case Study in Addis Ababa, Ethiopia." Environmental Geology 58(1):55-59. 
Abotalib, Abotalib Z., Mohamed Sultan, and Racha Elkadiri. 2016. "Groundwater Processes in Saharan Africa: Implications for Landscape Evolution in Arid Environments." Earth-Science Reviews 156:108-36.

Abouelmagd, Abdou, Mohamed Sultan, Adam Milewski, Alan E. Kehew, Neil C. Sturchio, Farouk Soliman, R. V. Krishnamurthy, and Elen Cutrim. 2012. "Toward a Better Understanding of Palaeoclimatic Regimes That Recharged the Fossil Aquifers in North Africa: Inferences from Stable Isotope and Remote Sensing Data.” Palaeogeography, Palaeoclimatology, Palaeoecology 329-330:137-49.

Abu-Hamdeh, N. H. 2004. "The Effect of Tillage Treatments on Soil Water Holding Capacity and on Soil Physical Properties." 13th International Soil Conservation Organisation Conference (669):1-6.

Acosta, Verónica Torres, Taylor F. Schildgen, Brian A. Clarke, Dirk Scherler, Bodo Bookhagen, Hella Wittmann, Friedhelm Von Blanckenburg, and Manfred R. Strecker. 2015. "Effect of Vegetation Cover on Millennial-Scale Landscape Denudation Rates in East Africa." Lithosphere 7(4):408-20.

Adams, S., R. Titus, and Y. Xu. 2004. Groundwater Recharge Assessment of the Basement Aquifers of Central Namaqualand. Vol. No. 1093/1.

Addai, Millicent Obeng, Sandow Mark Yidana, Larry Pax Chegbeleh, Dickson Adomako, and Bruce Banoeng-Yakubo. 2016. "Groundwater Recharge Processes in the Nasia Sub-Catchment of the White Volta Basin: Analysis of Porewater Characteristics in the Unsaturated Zone." Journal of African Earth Sciences 122:4-14.

Adelana, S. M. A., T. A. Abiye, D. C. W. Nkhuwa, C. Tindimugaya, and M. S. Oga. 2008. "Urban Groundwater Management and Protection in Sub-Saharan Africa." Pp. 231-60 in Applied Groundwater Studies in Africa.

Agassi, M., I. Shainberg, and J. Morin. 1981. "Effect of Electrolyte Concentration and Soil Sodicity on Infiltration Rate and Crust Formation." Soil Science Society of America Journal 45(5):84851.

Alaoui, Abdallah, Magdalena Rogger, Stephan Peth, and Günter Blöschl. 2018. "Does Soil Compaction Increase Floods? A Review." Journal of Hydrology 557:631-42.

Aly, A. I. M., K. Froehlich, A. Nada, M. Awad, M. Hamza, and W. M. Salem. 1993. "Study of Environmental Isotope Distribution in the Aswan High Dam Lake (Egypt) for Estimation of Evaporation of Lake Water and Its Recharge to Adjacent Groundwater." Environmental Geochemistry and Health 15(1):37-49.

Attandoh, Nelson, Sandow Mark Yidana, Aliou Abdul-Samed, Patrick Asamoah Sakyi, Bruce Banoeng-Yakubo, and Prosper M. Nude. 2013. "Conceptualization of the Hydrogeological System of Some Sedimentary Aquifers in Savelugu-Nanton and Surrounding Areas, Northern Ghana." Hydrological Processes 27(11):1664-76.

Awad, M. A., A. A. Nada, M. S. Hamza, and K. Froehlich. 1995. "Chemical and Isotopic Investigation of Groundwater in Tahta Region, Sohag-Egypt." Environmental Geochemistry and Health 17(3):147-53.

Ayadi, Yosra, Naziha Mokadem, Houda Besser, Faten Khelifi, Samia Harabi, Amor Hamad, Adrian Boyce, Rabah Laouar, and Younes Hamed. 2018. "Hydrochemistry and Stable Isotopes ( $\delta 18 \mathrm{O}$ and $\delta 2 \mathrm{H}$ ) Tools Applied to the Study of Karst Aquifers in Southern Mediterranean Basin (Teboursouk Area, NW Tunisia)." Journal of African Earth Sciences 137:208-17.

Azagegn, Tilahun, Asfawossen Asrat, Tenalem Ayenew, and Seifu Kebede. 2015. "Litho-Structural Control on Interbasin Groundwater Transfer in Central Ethiopia." Journal of African Earth 
Bakalowicz, Michel. 2005. "Karst Groundwater: A Challenge for New Resources.” Hydrogeology Journal 13(1):148-60.

Banks, Eddie W., Peter G. Cook, Michael Owor, Joseph Okullo, Seifu Kebede, Dessie Nedaw, Prince Mleta, Helen Fallas, Daren Gooddy, Donald John MacAllister, Theresa Mkandawire, Patrick Makuluni, Chikondi E. Shaba, and Alan M. MacDonald. 2021. "Environmental Tracers to Evaluate Groundwater Residence Times and Water Quality Risk in Shallow Unconfined Aquifers in Sub Saharan Africa." Journal of Hydrology 598.

Barbeta, Adrià and Josep Peñuelas. 2017. "Relative Contribution of Groundwater to Plant Transpiration Estimated with Stable Isotopes." Scientific Reports 7(1):1-10.

Bargués Tobella, A., H. Reese, A. Almaw, J. Bayala, A. Malmer, H. Laudon, and U. Ilstedt. 2014. "The Effect of Trees on Preferential Flow and Soil Infiltrability in an Agroforestry Parkland in Semiarid Burkina Faso." Water Resources Research 50(4):3342-54.

Beck, Hylke E., Albert I. J. M. Van Dijk, Diego G. Miralles, Richard A. M. De Jeu, L. A. Bruijnzeel, Tim R. McVicar, and Jaap Schellekens. 2013. "Global Patterns in Base Flow Index and Recession Based on Streamflow Observations from 3394 Catchments." Water Resources Research.

Befus, Kevin M., Scott Jasechko, Elco Luijendijk, Tom Gleeson, and M. Bayani Cardenas. 2017. "The Rapid yet Uneven Turnover of Earth's Groundwater." Geophysical Research Letters 44(11):5511-20.

Benito, Gerardo, Rick Rohde, Mary Seely, Christoph Külls, Ofer Dahan, Yehouda Enzel, Simon Todd, Blanca Botero, Efrat Morin, Tamir Grodek, and Carole Roberts. 2010. "Management of Alluvial Aquifers in Two Southern African Ephemeral Rivers: Implications for IWRM." Water Resources Management 24(4):641-67.

Berghuijs, W. R., R. A. Woods, and M. Hrachowitz. 2014. "A Precipitation Shift from Snow towards Rain Leads to a Decrease in Streamflow." Nature Climate Change 4(7):583-86.

Beven, Keith and Peter Germann. 1982. "Macropores and Water Flow in Soils." Water Resources Research 18(5):1311-25.

Bezdek, James C. 1981. Pattern Recognition with Fuzzy Objective Function Algorithms. New York: Plenum Press.

Bonsor, H. C., A. M. Macdonald, and J. Davies. 2014. "Evidence for Extreme Variations in the Permeability of Laterite from a Detailed Analysis of Well Behaviour in Nigeria." Hydrological Processes 28(10):3563-73.

Bouchaou, L., J. L. Michelot, A. Vengosh, Y. Hsissou, M. Qurtobi, C. B. Gaye, T. D. Bullen, and G. M. Zuppi. 2008. "Application of Multiple Isotopic and Geochemical Tracers for Investigation of Recharge, Salinization, and Residence Time of Water in the Souss-Massa Aquifer, Southwest of Morocco." Journal of Hydrology 352(3-4):267-87.

Bouimouass, Houssne, Younes Fakir, Sarah Tweed, and Marc Leblanc. 2020. "Groundwater Recharge Sources in Semiarid Irrigated Mountain Fronts." Hydrological Processes 34(7):15981615 .

Boukhari, K., Y. Fakir, T. Y. Stigter, Y. Hajhouji, and G. Boulet. 2015. "Origin of Recharge and Salinity and Their Role on Management Issues of a Large Alluvial Aquifer System in the SemiArid Haouz Plain, Morocco.” Environmental Earth Sciences 73(10):6195-6212.

Bouvet, Alexandre, Stéphane Mermoz, Thuy Le Toan, Ludovic Villard, Renaud Mathieu, Laven Naidoo, and Gregory P. Asner. 2018. "An above-Ground Biomass Map of African Savannahs 
and Woodlands at 25 M Resolution Derived from ALOS PALSAR." Remote Sensing of Environment 206:156-73.

Bromley, J., W. M. Edmunds, E. Fellman, J. Brouwer, S. R. Gaze, J. Sudlow, and J. D. Taupin. 1997. "Estimation of Rainfall Inputs and Direct Recharge to the Deep Unsaturated Zone of Southern Niger Using the Chloride Profile Method." Journal of Hydrology 188-189(1-4):139-54.

Brown, Molly E., Kirsten de Beurs, and Anton Vrieling. 2010. "The Response of African Land Surface Phenology to Large Scale Climate Oscillations." Remote Sensing of Environment 114(10):2286-96.

Brunner, Philip, Peter Bauer, Martin Eugster, and Wolfgang Kinzelbach. 2004. "Using Remote Sensing to Regionalize Local Precipitation Recharge Rates Obtained from the Chloride Method." Journal of Hydrology 294(4):241-50.

Brunner, Philip, Peter G. Cook, and Craig T. Simmons. 2009. "Hydrogeologic Controls on Disconnection between Surface Water and Groundwater." Water Resources Research 45(W01422).

Bullock, A. and M. Acreman. 2003. "The Role of Wetlands in the Hydrological Cycle." Hydrology and Earth System Sciences 7(3):358-89.

Burgess, Stephen S. O., Mark A. Adams, Neil C. Turner, Don A. White, and Chin K. Ong. 2001. "Tree Roots: Conduits for Deep Recharge of Soil Water." Oecologia 126(2):158-65.

Burke, Antje. 2003. "Inselbergs in a Changing World - Global Trends." Diversity and Distributions $9(5): 375-83$.

Butterworth, J. A., D. M. J. Macdonald, J. Bromley, L. P. Simmonds, C. J. Lovell, and F. Mugabe. 1999. "Hydrological Processes and Water Resources Management in a Dryland Environment III: Groundwater Recharge and Recession in a Shallow Weathered Aquifer." Hydrology and Earth System Sciences 3(3):345-51.

Carter, R. C. and A. G. Alkali. 1996. "Shallow Groundwater in the Northeast Arid Zone of Nigeria." Quarterly Journal of Engineering Geology 29(4):341-55.

Causse, C. 1989. "Two High Levels of Continental Waters in the Southern Tunisian Chotts at about 90 and 150 Ka." Geology 17(10):922-25.

Chemseddine, Fehdi, Belfar Dalila, and Baali Fethi. 2015. "Characterization of the Main Karst Aquifers of the Tezbent Plateau, Tebessa Region, Northeast of Algeria, Based on Hydrogeochemical and Isotopic Data.” Environmental Earth Sciences 74(1):241-50.

Crouvi, Onn, Rivka Amit, Yehouda Enzel, and Alan R. Gillespie. 2010. “Active Sand Seas and the Formation of Desert Loess.” Quaternary Science Reviews 29(17-18):2087-98.

Cuthbert, M. O., T. Gleeson, N. Moosdorf, K. M. Befus, A. Schneider, J. Hartmann, and B. Lehner. 2019. "Global Patterns and Dynamics of Climate-groundwater Interactions." Nature Climate Change 9(2):137-41.

Cuthbert, M. O. and C. Tindimugaya. 2010. "The Importance of Preferential Flow in Controlling Groundwater Recharge in Tropical Africa and Implications for Modelling the Impact of Climate Change on Groundwater Resources." Journal of Water and Climate Change 1(4):234-45.

Cuthbert, Mark O., Richard G. Taylor, Guillaume Favreau, Martin C. Todd, Mohammad Shamsudduha, Karen G. Villholth, Alan M. MacDonald, Bridget R. Scanlon, D. O.Valerie Kotchoni, Jean-Michel Vouillamoz, Fabrice M. A. Lawson, Philippe Armand Adjomayi, Japhet Kashaigili, David Seddon, James P. R. Sorensen, Girma Yimer Ebrahim, Michael Owor, Philip M. Nyenje, Yahaya Nazoumou, Ibrahim Goni, Boukari Issoufou Ousmane, Tenant Sibanda, Matthew J. Ascott, David M. J. Macdonald, William Agyekum, Youssouf Koussoubé, Heike 
Wanke, Hyungjun Kim, Yoshihide Wada, Min-Hui Lo, Taikan Oki, and Neno Kukuric. 2019. "Observed Controls on Resilience of Groundwater to Climate Variability in Sub-Saharan Africa." Nature 572(7768):230-34.

Dabous, A. A. and J. K. Osmond. 2001. "Uranium Isotopic Study of Artesian and Pluvial Contributions to the Nubian Aquifer, Western Desert, Egypt." Journal of Hydrology 243(34):242-53.

Dassi, Lassaad, Kamel Zouari, and Serigne Faye. 2005. "Identifying Sources of Groundwater Recharge in the Merguellil Basin (Tunisia) Using Isotopic Methods: Implication of Dam Reservoir Water Accounting." Environmental Geology 49(1):114-23.

Demlie, Molla. 2015. "Assessment and Estimation of Groundwater Recharge for a Catchment Located in Highland Tropical Climate in Central Ethiopia Using Catchment Soil-water Balance (SWB) and Chloride Mass Balance (CMB) Techniques." Environmental Earth Sciences 74(2):1137-50.

Demlie, Molla, Stefan Wohnlich, Birhanu Gizaw, and Willibald Stichler. 2007. "Groundwater Recharge in the Akaki Catchment, Central Ethiopia: Evidence from Environmental Isotopes ( $\delta 18 \mathrm{O}, \delta 2 \mathrm{H}$ and3H) and Chloride Mass Balance." Hydrological Processes 21(6):807-18.

Descheemaeker, Katrien, Jan Nyssen, Jean Poesen, Dirk Raes, Mitiku Haile, Bart Muys, and Seppe Deckers. 2006. "Runoff on Slopes with Restoring Vegetation: A Case Study from the Tigray Highlands, Ethiopia." Journal of Hydrology 331(1-2):219-41.

Descroix, L., G. Mahé, T. Lebel, G. Favreau, S. Galle, E. Gautier, J. C. Olivry, J. Albergel, O. Amogu, B. Cappelaere, R. Dessouassi, A. Diedhiou, E. Le Breton, I. Mamadou, and D. Sighomnou. 2009. "Spatio-Temporal Variability of Hydrological Regimes around the Boundaries between Sahelian and Sudanian Areas of West Africa: A Synthesis." Journal of Hydrology 375(1-2):90-102.

Diamond, R. E. and C. Harris. 2000. "Oxygen and Hydrogen Isotope Geochemistry of Thermal Springs of the Western Cape, South Africa: Recharge at High Altitude?" Journal of African Earth Sciences 31(3-4):467-81.

Dietrich, William E. and J.Taylor Perron. 2006. "The Search for a Topographic Signature of Life." Nature 439(7075):411-18.

Dillon, P., P. Stuyfzand, T. Grischek, M. Lluria, R. D. G. Pyne, R. C. Jain, J. Bear, J. Schwarz, W. Wang, E. Fernandez, C. Stefan, M. Pettenati, J. van der Gun, C. Sprenger, G. Massmann, B. R. Scanlon, J. Xanke, P. Jokela, Y. Zheng, R. Rossetto, M. Shamrukh, P. Pavelic, E. Murray, A. Ross, J. P. Bonilla Valverde, A. Palma Nava, N. Ansems, K. Posavec, K. Ha, R. Martin, and M. Sapiano. 2019. "Sixty Years of Global Progress in Managed Aquifer Recharge.” Hydrogeology Journal 27(1):1-30.

Diouf, Coly. 2012. "Combined Uses of Water-Table Fluctuation (WTF), Chloride Mass Balance (CMB) and Environmental Isotopes Methods to Investigate Groundwater Recharge in the Thiaroye Sandy Aquifer (Dakar, Senegal)." African Journal of Environmental Science and Technology 6(11):425-37.

Döll, P. and K. Fiedler. 2008. "Global-Scale Modeling of Groundwater Recharge.” Hydrology and Earth System Sciences 12(3):863-85.

Donchyts, Gennadii, Fedor Baart, Hessel Winsemius, Noel Gorelick, Jaap Kwadijk, and Nick Van De Giesen. 2016. "Earth's Surface Water Change over the Past 30 Years." Nature Climate Change 6:810-13.

Edmunds, W. M., W. G. Darling, D. G. Kinniburgh, S. Kotoub, and S. Mahgoub. 1992. "Sources of Recharge at Abu Delaig, Sudan.” Journal of Hydrology 131(1-4):1-24. 
Edmunds, W. M., E. Fellman, and I. B. Goni. 1999. "Lakes, Groundwater and Palaeohydrology in the Sahel of NE Nigeria: Evidence from Hydrogeochemistry." Journal of the Geological Society 156(2):345-55.

Edmunds, W. M. and C. B. Gaye. 1994. "Estimating the Spatial Variability of Groundwater Recharge in the Sahel Using Chloride." Journal of Hydrology 156(1-4):47-59.

Egli, Markus and Jérôme Poulenard. 2016. "Soils of Mountainous Landscapes.” Pp. 1-10 in International Encyclopedia of Geography: People, the Earth, Environment and Technology.

Fan, Ruqin, Xiaoping Zhang, Xueming Yang, Aizhen Liang, Shuxia Jia, and Xuewen Chen. 2013. "Effects of Tillage Management on Infiltration and Preferential Flow in a Black Soil, Northeast China.” Chinese Geographical Science 23(3):312-20.

FAO. 2018. "AQUASTAT.” Food and Agriculture Organization of the United Nations.

FAO-Food and Agriculture Organization of the United Nations. 2001. World Soil Resources Reports Lecture Notes on the Major Soils of the World.

Farid, Intissar, Kamel Zouari, Rim Trabelsi, and Abd Rahmen Kallali. 2014. “Application of Environmental Tracers to Study Groundwater Recharge in a Semi-Arid Area of Central Tunisia." Hydrological Sciences Journal 59(11):2072-85.

Faulkner, R. D. and R. A. Lambert. 1991. "The Effect of Irrigation on Dambo Hydrology: A Case Study." Journal of Hydrology 123(1-2):147-61.

Favreau, G., B. Cappelaere, S. Massuel, M. Leblanc, M. Boucher, N. Boulain, and C. Leduc. 2009. "Land Clearing, Climate Variability, and Water Resources Increase in Semiarid Southwest Niger: A Review." Water Resources Research 45(7):W00A16.

Flury, Markus, Hannes Flühler, William A. Jury, and Jörg Leuenberger. 1994. "Susceptibility of Soils to Preferential Flow of Water: A Field Study." Water Resources Research 30(7):1945-54.

Ford, Derek and Paul Williams. 2007. Karst Hydrogeology and Geomorphology.

Foster, S. S. D., A. H. Bath, J. L. Farr, and W. J. Lewis. 1982. "The Likelihood of Active Groundwater Recharge in the Botswana Kalahari.” Journal of Hydrology 55(1-4):113-36.

Foster, S. S. D., B. L. Morris, and P. J. Chilton. 1999. "Groundwater in Urban Development-a Review of Linkages and Concerns." IAHS-AISH Publication (259):3-12.

Foster, Stephen, Antonio Pulido-Bosch, Ángela Vallejos, Luis Molina, Armando Llop, and Alan M. MacDonald. 2018. "Impact of Irrigated Agriculture on Groundwater-Recharge Salinity: A Major Sustainability Concern in Semi-Arid Regions.” Hydrogeology Journal 26(8):2781-91.

Francis, M. L., M. V. Fey, H. P. Prinsloo, F. Ellis, A. J. Mills, and T. V. Medinski. 2007. "Soils of Namaqualand: Compensations for Aridity." Journal of Arid Environments 70(4):588-603.

Fujioka, Toshiyuki and John Chappell. 2011. "Desert Landscape Processes on a Timescale of Millions of Years, Probed by Cosmogenic Nuclides." Aeolian Research 3(2):157-64.

Gebreyohannes, Tesfamichael, Florimond De Smedt, Kristine Walraevens, Solomon Gebresilassie, Abdelwasie Hussien, Miruts Hagos, Kasa Amare, Jozef Deckers, and Kindeya Gebrehiwot. 2013. "Application of a Spatially Distributed Water Balance Model for Assessing Surface Water and Groundwater Resources in the Geba Basin, Tigray, Ethiopia." Journal of Hydrology 499:110-23.

Genthon, P., B. Hector, A. Luxereau, M. Descloitres, H. Abdou, J. Hinderer, and M. Bakalowicz. 2015. "Groundwater Recharge by Sahelian Rivers - consequences for Agricultural Development: Example from the Lower Komadugu Yobe River (Eastern Niger, Lake Chad Basin)." Environmental Earth Sciences 74(2):1291-1302. 
Gheith, Hazem and Mohamed Sultan. 2002. "Construction of a Hydrologic Model for Estimating Wadi Runoff and Groundwater Recharge in the Eastern Desert, Egypt." Journal of Hydrology 263(1-4):36-55.

Giertz, S. and B. Diekkrüger. 2003. "Analysis of the Hydrological Processes in a Small Headwater Catchment in Benin (West Africa)." Physics and Chemistry of the Earth 28(33-36):1333-41.

Goes, B. J. M. 1999. "Estimate of Shallow Groundwater Recharge in the Hadejia-Nguru Wetlands, Semi-Arid Northeastern Nigeria." Hydrogeology Journal 7(3):294-304.

Good, Stephen P., David Noone, and Gabriel Bowen. 2015. "Hydrologic Connectivity Constrains Partitioning of Global Terrestrial Water Fluxes." Science 349(6244):175-77.

Gordon, N. D., T. A. McMahon, and B. L. Finlayson. 2004. Stream Hydrology: An Introduction for Ecologists. 2nd ed. Wiley.

Grodek, Tamir, Efrat Morin, David Helman, Itamar Lensky, Ofer Dahan, Mary Seely, Gerardo Benito, and Yehouda Enzel. 2020. "Eco-Hydrology and Geomorphology of the Largest Floods along the Hyperarid Kuiseb River, Namibia." Journal of Hydrology 582(124450).

Grönwall, Jenny and Sampson Oduro-Kwarteng. 2018. "Groundwater as a Strategic Resource for Improved Resilience: A Case Study from Peri-Urban Accra.” Environmental Earth Sciences $77(6)$.

Guendouz, A., A. S. Moulla, B. Remini, and J. L. Michelot. 2006. "Hydrochemical and Isotopic Behaviour of a Saharan Phreatic Aquifer Suffering Severe Natural and Anthropic Constraints (Case of Oued-Souf Region, Algeria)." Hydrogeology Journal 14(6):955-68.

Gutmann, Ethan D. and Eric E. Small. 2007. "A Comparison of Land Surface Model Soil Hydraulic Properties Estimated by Inverse Modeling and Pedotransfer Functions." Water Resources Research 43(5):1-13.

Hamza, M. A. and W. K. Anderson. 2005. "Soil Compaction in Cropping Systems: A Review of the Nature, Causes and Possible Solutions." Soil and Tillage Research 82(2):121-45.

Hansen, M. C., P. V. Potapov, R. Moore, M. Hancher, S. A. Turubanova, A. Tyukavina, D. Thau, S. V. Stehman, S. J. Goetz, T. R. Loveland, A. Kommareddy, A. Egorov, L. Chini, C. O. Justice, and J. R. G. Townshend. 2013. "High-Resolution Global Maps of 21st-Century Forest Cover Change." Science 342(6160):850-53.

Hartmann, Andreas, Tom Gleeson, Yoshihide Wada, and Thorsten Wagener. 2017. "Enhanced Groundwater Recharge Rates and Altered Recharge Sensitivity to Climate Variability through Subsurface Heterogeneity." Proceedings of the National Academy of Sciences 114(11):2842-47.

Hawinkel, P., W. Thiery, S. Lhermitte, E. Swinnen, B. Verbist, J. Van Orshoven, and B. Muys. 2016. "Vegetation Response to Precipitation Variability in East Africa Controlled by Biogeographical Factors." Journal of Geophysical Research: Biogeosciences 121(9):2422-44.

Healy, Richard W. 2010. Estimating Groundwater Recharge. Cambridge: Cambridge University Press.

von der Heyden, Constantin J. 2004. "The Hydrology and Hydrogeology of Dambos: A Review." Progress in Physical Geography 28(4):544-64.

Holland, M. and K. T. Witthüser. 2009. "Geochemical Characterization of Karst Groundwater in the Cradle of Humankind World Heritage Site, South Africa.” Environmental Geology 57(3):51324.

Houston, J. F. T. 1982. "Rainfall and Recharge to a Dolomite Aquifer in a Semi-Arid Climate at Kabwe, Zambia." Journal of Hydrology 59(1-2):173-87. 
Howard, Ken W. F. and John Karundu. 1992. "Constraints on the Exploitation of Basement Aquifers in East Africa - Water Balance Implications and the Role of the Regolith." Journal of Hydrology 139(1-4):183-96.

Howison, Ruth A., Han Olff, Johan van de Koppel, and Christian Smit. 2017. "Biotically Driven Vegetation Mosaics in Grazing Ecosystems: The Battle between Bioturbation and Biocompaction.” Ecological Monographs 87(3):363-78.

Hubert, Lawrence and Phipps Arabie. 1985. "Comparing Partitions." Journal of Classification 2:193218.

Hut, Rolf, Maurits Ertsen, Naziema Joeman, Niels Vergeer, Hessel Winsemius, and Nick van de Giesen. 2008. "Effects of Sand Storage Dams on Groundwater Levels with Examples from Kenya." Physics and Chemistry of the Earth 33(1-2):56-66.

Ilstedt, U., A. Bargués Tobella, H. R. Bazié, J. Bayala, E. Verbeeten, G. Nyberg, J. Sanou, L. Benegas, D. Murdiyarso, H. Laudon, D. Sheil, and A. Malmer. 2016. "Intermediate Tree Cover Can Maximize Groundwater Recharge in the Seasonally Dry Tropics." Scientific Reports 6(21930).

Isiorho, S. A., G. Matisoff, and K. S. Wehn. 1996. "Seepage Relationships between Lake Chad and the Chad Aquifers." Ground Water 34(5):819-26.

Ivkovic, Karen M. 2009. “A Top-down Approach to Characterise Aquifer-River Interaction Processes." Journal of Hydrology 365(3-4):145-55.

Jacks, Gunnar and Matallah S. Traoré. 2014. "Mechanisms and Rates of Groundwater Recharge at Timbuktu, Republic of Mali." Journal of Hydrologic Engineering 19(2):422-27.

Jasechko, Scott. 2019. “Global Isotope Hydrogeology—Review.” Reviews of Geophysics 57(3):835965.

Jasechko, Scott, S.Jean Birks, Tom Gleeson, Yoshihide Wada, Peter J. Fawcett, Zachary D. Sharp, Jeffrey J. McDonnell, and Jeffrey M. Welker. 2014. "The Pronounced Seasonality of Global Groundwater Recharge." Water Resources Research 50(11):8845-67.

Jasechko, Scott, Debra Perrone, Kevin M. Befus, M. Bayani Cardenas, Grant Ferguson, Tom Gleeson, Elco Luijendijk, Jeffrey J. McDonnell, Richard G. Taylor, Yoshihide Wada, and James W. Kirchner. 2017. "Global Aquifers Dominated by Fossil Groundwaters but Wells Vulnerable to Modern Contamination.” Nature Geoscience 10(6):425-29.

Jasechko, Scott and Richard G. Taylor. 2015. "Intensive Rainfall Recharges Tropical Groundwaters." Environmental Research Letters 10(12):124015.

Jenny, Hans. 1941. Factors of Soil Formation. A System of Quantitative Pedology, Soil Science.

Kahiu, M. N. and N. P. Hanan. 2018. "Estimation of Woody and Herbaceous Leaf Area Index in SubSaharan Africa Using MODIS Data." Journal of Geophysical Research: Biogeosciences 123(1):3-17.

Kamtchueng, Brice Tchakam, Wilson Yetoh Fantong, Mengnjo Jude Wirmvem, Rosine Edwige Tiodjio, Alain Fouépé Takounjou, Kazuyoshi Asai, Serges L. Bopda Djomou, Minoru Kusakabe, Takeshi Ohba, Gregory Tanyileke, Joseph Victor Hell, and Akira Ueda. 2015. “A Multi-Tracer Approach for Assessing the Origin, Apparent Age and Recharge Mechanism of Shallow Groundwater in the Lake Nyos Catchment, Northwest, Cameroon." Journal of Hydrology 523:790-803.

Kebede, Seifu, Yves Travi, Tamiru Alemayehu, and Tenalem Ayenew. 2005. "Groundwater Recharge, Circulation and Geochemical Evolution in the Source Region of the Blue Nile River, Ethiopia." Applied Geochemistry 20(9):1658-76. 
Kebede, Seifu, Yves Travi, Asfawossen Asrat, Tamiru Alemayehu, Tenalem Ayenew, and Zenaw Tessema. 2008. "Groundwater Origin and Flow along Selected Transects in Ethiopian Rift Volcanic Aquifers.” Hydrogeology Journal 16(1):55-73.

Kim, John H. and Robert B. Jackson. 2012. "A Global Analysis of Groundwater Recharge for Vegetation, Climate, and Soils." Vadose Zone Journal 11(1).

Knoben, Wouter J. M., Ross A. Woods, and Jim E. Freer. 2019. "Global Bimodal Precipitation Seasonality: A Systematic Overview.” International Journal of Climatology 39(1):558-67.

Kocurek, Gary. 1988. "First-Order and Super Bounding Surfaces in Eolian Sequences-Bounding Surfaces Revisited." Sedimentary Geology 56(1-4):193-206.

Kotchoni, D. O.Valeri., Jean Michel Vouillamoz, Fabrice M. A. Lawson, Philippe Adjomayi, Moussa Boukari, and Richard G. Taylor. 2018. "Relationships between Rainfall and Groundwater Recharge in Seasonally Humid Benin: A Comparative Analysis of Long-Term Hydrographs in Sedimentary and Crystalline Aquifers." Hydrogeology Journal 27:447-457.

Lal, R. 1976. "No-Tillage Effects on Soil Properties under Different Crops in Western Nigeria." Soil Science Society of America Journal 40(5):762-68.

Lapworth, D. J., D. C. W. Nkhuwa, J. Okotto-Okotto, S. Pedley, M. E. Stuart, M. N. Tijani, and J. Wright. 2017. "Urban Groundwater Quality in Sub-Saharan Africa: Current Status and Implications for Water Security and Public Health." Hydrogeology Journal 25:1093-1116.

Leblanc, Marc, Guillaume Favreau, Sarah Tweed, Christian Leduc, Moumtaz Razack, and Linus Mofor. 2007. "Remote Sensing for Groundwater Modelling in Large Semiarid Areas: Lake Chad Basin, Africa." Hydrogeology Journal 15(1):97-100.

Leblanc, Marc J., Guillaume Favreau, Sylvain Massuel, Sarah O. Tweed, Maud Loireau, and Bernard Cappelaere. 2008. "Land Clearance and Hydrological Change in the Sahel: SW Niger." Global and Planetary Change 61(3-4):135-50.

Leduc, C., G. Favreau, and P. Schroeter. 2001. "Long-Term Rise in a Sahelian Water-Table: The Continental Terminal in South-West Niger." Journal of Hydrology.

Lehner, B., C.Reidy Liermann, C. Revenga, C. Vorosmarty, B. Fekete, P. Crouzet, P. Doll, M. Endejan, K. Frenken, J. Magome, C. Nilsson, J. C. Robertson, R. Rodel, N. Sindorf, and D. Wisser. 2011. "Global Reservoir and Dam Database, Version 1 (GRanDv1): Reservoirs, Revision 01." NASA Socioeconomic Data and Applications Center (SEDAC). Retrieved January 5, 2019 (https://sedac.ciesin.columbia.edu/data/set/grand-v1-dams-rev01).

Lehner, Bernhard and Petra Döll. 2004. "Development and Validation of a Global Database of Lakes, Reservoirs and Wetlands." Journal of Hydrology 296(1-4):1-22.

Leketa, Khahliso, Tamiru Abiye, Silindile Zondi, and Michael Butler. 2019. “Assessing Groundwater Recharge in Crystalline and Karstic Aquifers of the Upper Crocodile River Basin, Johannesburg, South Africa." Groundwater for Sustainable Development 8:31-40.

Lerner, David N. 2002. "Identifying and Quantifying Urban Recharge: A Review." Hydrogeology Journal 10(1):143-52.

M.I, Budyko. 1974. Climate and Life. Academic Press, New York.

MacDonald, A. M., H. C. Bonsor, B. É. Ó. Dochartaigh, and R. G. Taylor. 2012. "Quantitative Maps of Groundwater Resources in Africa.” Environmental Research Letters 7(24009).

Mahmood, Rashid and Shaofeng Jia. 2019. "Assessment of Hydro-Climatic Trends and Causes of Dramatically Declining Stream Flow to Lake Chad, Africa, Using a Hydrological Approach." Science of the Total Environment 675:122-40. 
Markovich, Katherine H., Andrew H. Manning, Laura E. Condon, and Jennifer C. McIntosh. 2019. "Mountain-Block Recharge: A Review of Current Understanding." Water Resources Research 55(11):8278-8304.

Mayaux, Philippe, Etienne Bartholomé, Steffen Fritz, and Alan Belward. 2004. “A New Land-Cover Map of Africa for the Year 2000." Journal of Biogeography 31(6):861-77.

Mayes, Marc T., John F. Mustard, and Jerry M. Melillo. 2015. "Forest Cover Change in Miombo Woodlands: Modeling Land Cover of African Dry Tropical Forests with Linear Spectral Mixture Analysis." Remote Sensing of Environment 165:203-15.

Mazor, E., B.Th Verhagen, J. P. F. Sellschop, M. T. Jones, N. E. Robins, L. Hutton, and C. M. H. Jennings. 1977. "Northern Kalahari Groundwaters: Hydrologic, Istopic and Chemical Studies at Orapa, Botswana.” Journal of Hydrology 34(3-4):203-34.

Mazor, Emanuel. 1982. "Rain Recharge in the Kalahari - A Note on Some Approaches to the Problem." Journal of Hydrology 55(1-4):137-44.

McCartney, M. P. 2000. "The Water Budget of a Headwater Catchment Containing a Dambo." Physics and Chemistry of the Earth, Part B: Hydrology, Oceans and Atmosphere 25(7-8):61116.

McCartney, Matthew, John Butterworth, Patrick Moriarty, and Richard Owen. 1998. "Comparison of the Hydrology of Two Contrasting Headwater Catchments in Zimbabwe." IAHS-AISH Publication 248:515-22.

McFarlane, Margaret Joan. 1970. "Lateritization and Landscape Development in Kyagwe, Uganda." Quarterly Journal of the Geological Society of London 126(1-4):501-34.

Measho, Simon, Baozhang Chen, Yongyut Trisurat, Petri Pellikka, Lifeng Guo, Sunsanee Arunyawat, Venus Tuankrua, Woldeselassie Ogbazghi, and Tecle Yemane. 2019. "Spatio-Temporal Analysis of Vegetation Dynamics as a Response to Climate Variability and Drought Patterns in the Semiarid Region, Eritrea." Remote Sensing 11(6).

Mechal, Abraham, Steffen Birk, Gerfried Winkler, Thomas Wagner, and Aberra Mogessie. 2016. "Characterizing Regional Groundwater Flow in the Ethiopian Rift: A Multimodel Approach Applied to Gidabo River Basin.” Austrian Journal of Earth Sciences 109(1):68-83.

Mechal, Abraham, Thomas Wagner, and Steffen Birk. 2015. "Recharge Variability and Sensitivity to Climate: The Example of Gidabo River Basin, Main Ethiopian Rift." Journal of Hydrology: Regional Studies 4(B):644-60.

Meixner, Thomas, Andrew H. Manning, David A. Stonestrom, Diana M. Allen, Hoori Ajami, Kyle W. Blasch, Andrea E. Brookfield, Christopher L. Castro, Jordan F. Clark, David J. Gochis, Alan L. Flint, Kirstin L. Neff, Rewati Niraula, Matthew Rodell, Bridget R. Scanlon, Kamini Singha, and Michelle A. Walvoord. 2016. "Implications of Projected Climate Change for Groundwater Recharge in the Western United States." Journal of Hydrology 534:124-38.

Melanie A. Harsch, Philip E. Hulme, Matt S. McGlone, and Richard P. Duncan. 2009. "Are Treelines Advancing? A Global Meta-Analysis of Treeline Response to Climate Warming." Ecology Letters 12(10):1040-49.

Miralles, Diego G., John H. Gash, Thomas R. H. Holmes, Richard A. M. De Jeu, and A. J. Dolman. 2010. "Global Canopy Interception from Satellite Observations." Journal of Geophysical Research Atmospheres 115(D16122).

Moeck, Christian, Nicolas Grech-Cumbo, Joel Podgorski, Anja Bretzler, Jason J. Gurdak, Michael Berg, and Mario Schirmer. 2020. "A Global-Scale Dataset of Direct Natural Groundwater Recharge Rates: A Review of Variables, Processes and Relationships." Science of the Total Environment 717(137042). 
Mohan, Chinchu, Andrew W. Western, Yongping Wei, and Margarita Saft. 2018. "Predicting Groundwater Recharge for Varying Land Cover and Climate Conditions-a Global Meta-Study." Hydrology and Earth System Sciences 22(5):2689-2703.

Morin, Efrat, Tamir Grodek, Ofer Dahan, Gerardo Benito, Christoph Kulls, Yael Jacoby, Guido Van Langenhove, Mary Seely, and Yehouda Enzel. 2009. "Flood Routing and Alluvial Aquifer Recharge along the Ephemeral Arid Kuiseb River, Namibia." Journal of Hydrology 368(14):262-75.

Mrabet, Rachid. 2002. "Stratification of Soil Aggregation and Organic Matter under Conservation Tillage Systems in Africa." Soil and Tillage Research 66(2):119-28.

Nash, David J. and Paul A. Shaw. 1998. "Silica and Carbonate Relationships in Silcrete-Calcrete Intergrade Duricrusts from the Kalahari of Botswana and Namibia." Journal of African Earth Sciences 27(1):11-25.

Nash, David J., Paul A. Shaw, and David S. G. Thomas. 1994. "Duricrust Development and Valley Evolution: Process-landform Links in the Kalahari." Earth Surface Processes and Landforms 19(4):299-317.

Nciizah, Adornis D. and Isaiah I. C. Wakindiki. 2015. "Soil Sealing and Crusting Effects on Infiltration Rate: A Critical Review of Shortfalls in Prediction Models and Solutions." Archives of Agronomy and Soil Science 61(9):1211-30.

Ndehedehe, Christopher E., Vagner G. Ferreira, and Nathan O. Agutu. 2019. "Hydrological Controls on Surface Vegetation Dynamics over West and Central Africa." Ecological Indicators 103:494-508.

Ndlovu, M. and M. Demlie. 2016. "Hydrogeological Characterization of the Kosi Bay Lakes System, North-Eastern South Africa." Environmental Earth Sciences 75(1334).

Nicholson, S. E. 2000. "The Nature of Rainfall Variability over Africa on Time Scales of Decades to Millenia." Global and Planetary Change 26(1-3):137-58.

Nicholson, Sharon E. and Jeeyoung Kim. 1997. "The Relationship of the El MNO-Southern Oscillation to African Rainfall." International Journal of Climatology 17(2):117-35.

Nijzink, Remko, Christopher Hutton, Ilias Pechlivanidis, René Capell, Berit Arheimer, Jim Freer, Dawei Han, Thorsten Wagener, Kevin McGuire, Hubert Savenije, and Markus Hrachowitz. 2016. "The Evolution of Root-Zone Moisture Capacities after Deforestation: A Step towards Hydrological Predictions under Change?" Hydrology and Earth System Sciences 20(12):477599.

Nkotagu, Hudson. 1996. "Application of Environmental Isotopes to Groundwater Recharge Studies in a Semi-Arid Fractured Crystalline Basement Area of Dodoma, Tanzania." Journal of African Earth Sciences 22(4):443-57.

NOAA/OAR/ESRL PSD. n.d. “CPC Global Temperature Data.” Retrieved June 10, 2020 (https://psl.noaa.gov/data/gridded/data.cpc.globaltemp.html).

Oades, J. M. 1993. "The Role of Biology in the Formation, Stabilization and Degradation of Soil Structure.” Geoderma 56(1-4):377-400.

Ojiambo, Bwire S., Robert J. Poreda, and W.Berry Lyons. 2001. "Ground Water/surface Water Interactions in Lake Naivasha, Kenya, Using $\delta 18 \mathrm{O}, \delta \mathrm{D}$, and $3 \mathrm{H} / 3 \mathrm{He}$ Age-Dating." Ground Water 39(4):526-33.

Ojiambo, S.Bwire, W.Berry Lyons, Kathy A. Welch, Robert J. Poreda, and Karen H. Johannesson. 2003. "Strontium Isotopes and Rare Earth Elements as Tracers of Groundwater-Lake Water Interactions, Lake Naivasha, Kenya." Applied Geochemistry 18(11):1789-1805. 
Oldeman, L. R., R. T. A. Hakkeling, and W... G. Sombroek. 1990. World Map of the Status of Human-Induced Soil Degradation: An Explanatory Note. Vol. 7.

Osunbitan, J. A., D. J. Oyedele, and K. O. Adekalu. 2005. "Tillage Effects on Bulk Density, Hydraulic Conductivity and Strength of a Loamy Sand Soil in Southwestern Nigeria." Soil and Tillage Research 82(1):57-64.

Oteng Mensah, Felix, Clement Alo, and Sandow Mark Yidana. 2014. "Evaluation of Groundwater Recharge Estimates in a Partially Metamorphosed Sedimentary Basin in a Tropical Environment: Application of Natural Tracers." The Scientific World Journal 2014(419508).

Owor, M., R. G. Taylor, C. Tindimugaya, and D. Mwesigwa. 2009. "Rainfall Intensity and Groundwater Recharge: Empirical Evidence from the Upper Nile Basin.” Environmental Research Letters 4(35009).

Owor, Michael, Richard Taylor, Christine Mukwaya, and Callist Tindimugaya. 2011. "Groundwater/surface-Water Interactions on Deeply Weathered Surfaces of Low Relief: Evidence from Lakes Victoria and Kyoga, Uganda.” Hydrogeology Journal 19(7):1403-20.

Pachur, Hans Joachim and Philipp Hoelzmann. 2000. "Late Quaternary Palæoecology and Palæoclimates of the Eastern Sahara.” Journal of African Earth Sciences 30(4):929-39.

Pekel, Jean François, Andrew Cottam, Noel Gorelick, and Alan S. Belward. 2016. "High-Resolution Mapping of Global Surface Water and Its Long-Term Changes.” Nature 540(7633):418-22.

Ramberg, Lars, Piotr Wolski, and Martin Krah. 2006. "Water Balance and Infiltration in a Seasonal Floodplain in the Okaying Delta Botswana." Wetlands 26(3):677-90.

Randrup, Thomas B. 1997. "Soil Compaction on Construction Sites.” Journal of Arboriculture 23(5):207-10.

Rao Kolusu, Seshagiri, Mohammad Shamsudduha, Martin C. Todd, Richard G. Taylor, David Seddon, Japhet J. Kashaigili, Girma Y. Ebrahim, Mark O. Cuthbert, James P. R. Sorensen, Karen G. Villholth, Alan M. Macdonald, and Dave A. Macleod. 2019. "The El Niño Event of 2015-2016: Climate Anomalies and Their Impact on Groundwater Resources in East and Southern Africa." Hydrology and Earth System Sciences 23(3):1751-62.

Reinhardt, Liam, Douglas Jerolmack, Brad J. Cardinale, Veerle Vanacker, and Justin Wright. 2010. "Dynamic Interactions of Life and Its Landscape: Feedbacks at the Interface of Geomorphology and Ecology." Earth Surface Processes and Landforms 35(1):78-101.

Rueedi, J., M. S. Brennwald, R. Purtschert, U. Beyerle, M. Hofer, and R. Kipfer. 2005. "Estimating Amount and Spatial Distribution of Groundwater Recharge in the Lullemmeden Basin (Niger) Based on 3H, 3He and CFC-11 Measurements." Hydrological Processes 19(17):3285-98.

Saxton, K. E., W. J. Rawls, J. S. Romberger, and R. I. Papendick. 1986. "Estimating Generalized Soil-Water Characteristics from Texture.” Soil Science Society of America Journal 50(4):103136.

Scanlon, Bridget R., Richard W. Healy, and Peter G. Cook. 2002. "Choosing Appropriate Techniques for Quantifying Groundwater Recharge.” Hydrogeology Journal 10:18-39.

Scanlon, Bridget R., Ian Jolly, Marios Sophocleous, and Lu Zhang. 2007. "Global Impacts of Conversions from Natural to Agricultural Ecosystems on Water Resources: Quantity versus Quality." Water Resources Research 43(3).

Scanlon, Bridget R., Kelley E. Keese, Alan L. Flint, Lorraine E. Flint, Cheikh B. Gaye, W.Michael Edmunds, and Ian Simmers. 2006. "Global Synthesis of Groundwater Recharge in Semiarid and Arid Regions.” Hydrological Processes 20(15):3335-70.

Schlesinger, William H. and Scott Jasechko. 2014. "Transpiration in the Global Water Cycle." 
Schmied, Hannes Müller, Linda Adam, Stephanie Eisner, Gabriel Fink, Martina Flörke, Hyungjun Kim, Taikan Oki, Felix Theodor Portmann, Robert Reinecke, Claudia Riedel, Qi Song, Jing Zhang, and Petra Döll. 2016. "Impact of Climate Forcing Uncertainty and Human Water Use on Global and Continental Water Balance Components." Proceedings of the International Association of Hydrological Sciences 374:53-62.

Schwämmle, Veit and Ole Nørregaard Jensen. 2010. "A Simple and Fast Method to Determine the Parameters for Fuzzy c-Means Cluster Analysis." Bioinformatics 26(22):2841-48.

Séguis, L., B. Kamagaté, G. Favreau, M. Descloitres, J. L. Seidel, S. Galle, C. Peugeot, M. Gosset, L. Le Barbé, F. Malinur, S. Van Exter, M. Arjounin, S. Boubkraoui, and M. Wubda. 2011. "Origins of Streamflow in a Crystalline Basement Catchment in a Sub-Humid Sudanian Zone: The Donga Basin (Benin, West Africa). Inter-Annual Variability of Water Budget." Journal of Hydrology 402(1-2):1-13.

Sharp, John M. 2010. "The Impacts of Urbanization on Groundwater Systems and Recharge." Aquamundi 1(may):51-56.

Shiklomanov, I. .. and J. .. Rodda. 2004. "World Water Resources at the Beginning of the TwentyFirst Century." International Hydrology Series, Unesco 41(7):41-4063-41-4063.

Sibanda, Tenant, Johannes C. Nonner, and Stefan Uhlenbrook. 2009. "Comparison of Groundwater Recharge Estimation Methods for the Semi-Arid Nyamandhlovu Area, Zimbabwe." Hydrogeology Journal 17(6):1427-41.

Siebert, S., M. Kummu, M. Porkka, P. Döll, N. Ramankutty, and B. R. Scanlon. 2015. "A Global Data Set of the Extent of Irrigated Land from 1900 to 2005." Hydrology and Earth System Sciences 19(3):1521-45.

Smethurst, David. 2000. "Mountain Geography.” Geographical Review 90(1):35.

Sophocleous, Marios. 2002. "Interactions between Groundwater and Surface Water: The State of the Science." Hydrogeology Journal 10(1):52-67.

Spaan, W. P., A. F. S. Sikking, and W. B. Hoogmoed. 2005. "Vegetation Barrier and Tillage Effects on Runoff and Sediment in an Alley Crop System on a Luvisol in Burkina Faso." Soil and Tillage Research 83(2):194-203.

Stefan, Catalin and Nienke Ansems. 2018. "Web-Based Global Inventory of Managed Aquifer Recharge Applications." Sustainable Water Resources Management 4(2):153-62.

Stein, Lina, Francesca Pianosi, and Ross Woods. 2020. "Event-Based Classification for Global Study of River Flood Generating Processes." Hydrological Processes 34(7):1514-29.

Steward, Alisha L., Daniel Von Schiller, Klement Tockner, Jonathan C. Marshall, and Stuart E. Bunn. 2012. "When the River Runs Dry: Human and Ecological Values of Dry Riverbeds." Frontiers in Ecology and the Environment 10(4):202-9.

Stone, A. E. C. and W. M. Edmunds. 2012. "Sand, Salt and Water in the Stampriet Basin, Namibia: Calculating Unsaturated Zone (Kalahari Dunefield) Recharge Using the Chloride Mass Balance Approach.” Water SA 38(3):367-78.

Strudley, Mark W., Timothy R. Green, and James C. Ascough. 2008. "Tillage Effects on Soil Hydraulic Properties in Space and Time: State of the Science." Soil and Tillage Research 99(1):4-48.

Sturchio, N. C., X. Du, R. Purtschert, B. E. Lehmann, M. Sultan, L. J. Patterson, Z. T. Lu, P. Müller, T. Bigler, K. Bailey, T. P. O'Connor, L. Young, R. Lorenzo, R. Becker, Z. El Alfy, B. El Kaliouby, Y. Dawood, and A. M. A. Abdallah. 2004. "One Million Year Old Groundwater in 
the Sahara Revealed by Krypton-81 and Chlorine-36." Geophysical Research Letters 31(L05503).

Sultan, M., N. C. Sturchio, H. Gheith, Y. Abdel Hady, and M. El Anbeawy. 2000. "Chemical and Isotopic Constraints on the Origin of Wadi El-Tarfa Ground Water, Eastern Desert, Egypt." Ground Water 38(5):743-51.

Sultan, M., E. Yan, N. Sturchio, A. Wagdy, K. Abdel Gelil, R. Becker, N. Manocha, and A. Milewski. 2007. "Natural Discharge: A Key to Sustainable Utilization of Fossil Groundwater." Journal of Hydrology 335(1-2):25-36.

Sultan, Mohamed, Neil Sturchio, Fekri A. Hassan, Mohamed Abdel Rahman Hamdan, Abdel Moneim Mahmood, Zeinhom El Alfy, and Tom Stein. 1997. "Precipitation Source Inferred from Stable Isotopic Composition of Pleistocene Groundwater and Carbonate Deposits in the Western Desert of Egypt." Quaternary Research 48(1):29-37.

Tantawi, M. A., E. El-Sayed, and M. A. Awad. 1998. "Hydrochemical and Stable Isotope Study of Groundwater in the Saint Catherine-Wadi Feiran Area, South Sinai, Egypt." Journal of African Earth Sciences 26(2):277-84.

Tarki, Meriem, Lassaad Dassi, and Younes Jedoui. 2012. "Groundwater Composition and Recharge Origin in the Shallow Aquifer of the Djerid Oases, Southern Tunisia: Implications of Return Flow." Hydrological Sciences Journal 57(4):790-804.

Taylor, Richard G. and Ken W. F. Howard. 1996. "Groundwater Recharge in the Victoria Nile Basin of East Africa: Support for the Soil Moisture Balance Approach Using Stable Isotope Tracers and Flow Modelling." Journal of Hydrology 180(1-4):31-53.

Taylor, Richard G., Martin C. Todd, Lister Kongola, Louise Maurice, Emmanuel Nahozya, Hosea Sanga, and Alan M. Macdonald. 2013. "Evidence of the Dependence of Groundwater Resources on Extreme Rainfall in East Africa." Nature Climate Change 3:374-378.

Thierfelder, Christian, Mulundu Mwila, and Leonard Rusinamhodzi. 2013. "Conservation Agriculture in Eastern and Southern Provinces of Zambia: Long-Term Effects on Soil Quality and Maize Productivity." Soil and Tillage Research 126:246-58.

Thierfelder, Christian and Patrick C. Wall. 2009. "Effects of Conservation Agriculture Techniques on Infiltration and Soil Water Content in Zambia and Zimbabwe." Soil and Tillage Research 105(2):217-27.

Thompson, S. E., C. J. Harman, P. Heine, and G. G. Katul. 2010. "Vegetation-Infiltration Relationships across Climatic and Soil Type Gradients." Journal of Geophysical Research: Biogeosciences 115(G02023).

Tilahun, Seifu A., Debebe L. Yilak, Petra Schmitter, Fasikaw A. Zimale, Simon Langan, Jennie Barron, Jean Yves Parlange, and Tammo S. Steenhuis. 2020. "Establishing Irrigation Potential of a Hillside Aquifer in the African Highlands." Hydrological Processes 34(8):1741-53.

du Toit, G.van N., H. A. Snyman, and P. J. Malan. 2009. "Physical Impact of Grazing by Sheep on Soil Parameters in the Nama Karoo Subshrub/grass Rangeland of South Africa." Journal of Arid Environments 73(9):804-10.

Van Tonder, G. J. and J. Kirchner. 1990. "Estimation of Natural Groundwater Recharge in the Karoo Aquifers of South Africa." Journal of Hydrology 121(1-4):395-419.

Towett, Erick K., Keith D. Shepherd, Jerome E. Tondoh, Leigh A. Winowiecki, Tamene Lulseged, Mercy Nyambura, Andrew Sila, Tor G. Vågen, and Georg Cadisch. 2015. "Total Elemental Composition of Soils in Sub-Saharan Africa and Relationship with Soil Forming Factors." Geoderma Regional 5:157-68. 
Troch, P. A., G. Carrillo, M. Sivapalan, T. Wagener, and K. Sawicz. 2013. "Climate-Vegetation-Soil Interactions and Long-Term Hydrologic Partitioning: Signatures of Catchment Co-Evolution." Hydrology and Earth System Sciences 17(6):2209-17.

Tsendbazar, Nandin Erdene, Sytze de Bruin, and Martin Herold. 2017. "Integrating Global Land Cover Datasets for Deriving User-Specific Maps." International Journal of Digital Earth 10(3):219-37.

Umer, Y. M., V. G. Jetten, and J. Ettema. 2019. "Sensitivity of Flood Dynamics to Different Soil Information Sources in Urbanized Areas.” Journal of Hydrology 577(123945).

UNEP. 2010. “Africa Water Atlas”. Devision of Early Warning and Assessment (DEWA). Nairobi, Kenya.

Været, Lars, Bruce Kelbe, Sylvi Haldorsen, and Richard H. Taylor. 2009. "A Modelling Study of the Effects of Land Management and Climatic Variations on Groundwater Inflow to Lake St Lucia, South Africa." Hydrogeology Journal 17(8):1949-67.

van Vliet, Jasper. 2019. “Direct and Indirect Loss of Natural Area from Urban Expansion.” Nature Sustainability 2(8):755-63.

Vogel, J. C. and H. Van Urk. 1975. "Isotopic Composition of Groundwater in Semi-Arid Regions of Southern Africa." Journal of Hydrology 25(1-2):23-36.

de Vries, J. and A. Gieske. 1990. “A Simple Chloride Balance Routing Method to Regionalize Groundwater Recharge: A Case Study in Semiarid Botswana.” Pp. 81-89 in Regionalization in Hydrolo. he Ljubljan: IAHS Publ. no. 191.

De Vries, J. J., E. T. Selaolo, and H. E. Beekman. 2000. “Groundwater Recharge in the Kalahari, with Reference to Paleo-Hydrologic Conditions." Journal of Hydrology 238(1-2):110-23.

Wada, Yoshihide, L. P. H. Van Beek, and Marc F. P. Bierkens. 2012. "Nonsustainable Groundwater Sustaining Irrigation: A Global Assessment." Water Resources Research 48(1):W00L06.

Wakindiki, I. I. C. and M. Ben-Hur. 2002. "Soil Mineralogy and Texture Effects on Crust Micromorphology, Infiltration, and Erosion." Soil Science Society of America Journal 66(3):897-905.

Walker, David, Magdalena Smigaj, and Nebo Jovanovic. 2019. "Ephemeral Sand River Flow Detection Using Satellite Optical Remote Sensing.” Journal of Arid Environments 168:17-25.

Walraevens, Kristine, Tesfamichael Gebreyohannes Tewolde, Kassa Amare, Abdelwassie Hussein, Gebremedhin Berhane, Ruben Baert, Silke Ronsse, Samuel Kebede, Laure Van Hulle, Jozef Deckers, Kristine Martens, and Marc Van Camp. 2015. "Water Balance Components for Sustainability Assessment of Groundwater-Dependent Agriculture: Example of the Mendae Plain (Tigray, Ethiopia).” Land Degradation and Development 26(7):725-36.

Walraevens, Kristine, Ine Vandecasteele, Kristine Martens, Jan Nyssen, Jan Moeyersons, Tesfamichael Gebreyohannes, Florimond de Smedt, Jean Poesen, Jozef Deckers, and Marc van Camp. 2009. "Groundwater Recharge and Flow in a Small Mountain Catchment in Northern Ethiopia." Hydrological Sciences Journal 54(4):739-53.

Wanke, Heike, Armin Dünkeloh, and Peter Udluft. 2008. "Groundwater Recharge Assessment for the Kalahari Catchment of North-Eastern Namibia and North-Western Botswana with a RegionalScale Water Balance Model.” Water Resources Management 22:1143-1158.

Weitz, J. and M. Demlie. 2015. "Hydrogeological System Analyses of the Lake Sibayi Catchment, North-Eastern South Africa.” South African Journal of Geology 118(1):91-107.

Weitz, Jannie and Molla Demlie. 2014. "Conceptual Modelling of Groundwater-Surface Water Interactions in the Lake Sibayi Catchment, Eastern South Africa.” Journal of African Earth 
Wilson, John L. and Huade Guan. 2004. "Mountain-Block Hydrology and Mountain-Front Recharge." Pp. 113-37 in Groundwater Recharge in a Desert Environment: The Southwestern United States. Vol. 9, edited by J. F. Hogan, F. M. Phillips, and B. R. Scanlon.

Winter, Thomas C., Judson W. Harvey, O.Lehn Franke, and William M. Alley. 1998. Ground Water Surface Water and A Single Resource.

Wirmvem, Mengnjo Jude, Mumbfu Ernestine Mimba, Brice Tchakam Kamtchueng, Engome Regina Wotany, Tasin Godlove Bafon, Asobo Nkengmatia Elvis Asaah, Wilson Yetoh Fantong, Samuel Ndonwi Ayonghe, and Takeshi Ohba. 2015. "Shallow Groundwater Recharge Mechanism and Apparent Age in the Ndop Plain, Northwest Cameroon." Applied Water Science 7(1):489-502.

Wolski, P., H. H. G. Savenije, M. Murray-Hudson, and T. Gumbricht. 2006. "Modelling of the Flooding in the Okavango Delta, Botswana, Using a Hybrid Reservoir-GIS Model." Journal of Hydrology 331(1-2):58-72.

World Bank. 2019. “Urban Developmemt.” Retrieved November 21, 2019 (https://data.worldbank.org/topic/urban-development).

Wösten, J. H. M., Ya A. Pachepsky, and W. J. Rawls. 2001. "Pedotransfer Functions: Bridging the Gap between Available Basic Soil Data and Missing Soil Hydraulic Characteristics." Journal of Hydrology 251(3-4):123-50.

Wright, E. P. 1992. "The Hydrogeology of Crystalline Basement Aquifers in Africa." Geological Society Special Publication 66:1-27.

van Wyk, E., G. van Tonder, and D. Vermeulen. 2012. "Characteristics of Local Groundwater Recharge Cycles in South African Semi-Arid Hard Rock Terrains: Rainfall-Groundwater Interaction." Water SA 38(5):747-54.

Xiong, Jun, Prasad S. Thenkabail, Murali K. Gumma, Pardhasaradhi Teluguntla, Justin Poehnelt, Russell G. Congalton, Kamini Yadav, and David Thau. 2017. "Automated Cropland Mapping of Continental Africa Using Google Earth Engine Cloud Computing." ISPRS Journal of Photogrammetry and Remote Sensing 126:225-44.

Xu, Yongxin and Hans E. Beekman. 2003. Groundwater Recharge Estimation in Southern Africa. Vol. 64.

Yan, Zhongwei and Nicole Petit-Maire. 1994. "The Last $140 \mathrm{Ka}$ in the Afro-Asian Arid/semi-Arid Transitional Zone.” Palaeogeography, Palaeoclimatology, Palaeoecology 110(3-4):217-33.

Yenehun, Alemu, Kristine Walraevens, and Okke Batelaan. 2017. "Spatial and Temporal Variability of Groundwater Recharge in Geba Basin, Northern Ethiopia." Journal of African Earth Sciences 134:198-212.

Yidana, Sandow Mark and Eric Koffie. 2014. "The Groundwater Recharge Regime of Some Slightly Metamorphosed Neoproterozoic Sedimentary Rocks: An Application of Natural Environmental Tracers." Hydrological Processes 28(7):3104-17.

Zarfl, Christiane, Alexander E. Lumsdon, Jürgen Berlekamp, Laura Tydecks, and Klement Tockner. 2014. "A Global Boom in Hydropower Dam Construction." Aquatic Sciences 77(1):161-70.

Zhang, Yongqiang, Jorge L. Peña-Arancibia, Tim R. McVicar, Francis H. S. Chiew, Jai Vaze, Changming Liu, Xingjie Lu, Hongxing Zheng, Yingping Wang, Yi Y. Liu, Diego G. Miralles, and Ming Pan. 2016. "Multi-Decadal Trends in Global Terrestrial Evapotranspiration and Its Components." Scientific Reports 6(19124).

Zheng, Chaolei, Li Jia, Guangcheng Hu, Massimo Menenti, Jing Lu, Jie Zhou, Kun Wang, and Zhansheng Li. 2017. "Assessment of Water Use in Pan-Eurasian and African Continents by 

Environmental Science. Vol. 57.

Zhou, Liming, Yuhong Tian, Ranga B. Myneni, Philippe Ciais, Sassan Saatchi, Yi Y. Liu, Shilong Piao, Haishan Chen, Eric F. Vermote, Conghe Song, and Taehee Hwang. 2014. "Widespread Decline of Congo Rainforest Greenness in the Past Decade." Nature 508(7498):86-90.

Zhou, Yuyu, Steven J. Smith, Kaiguang Zhao, Marc Imhoff, Allison Thomson, Ben Bond-Lamberty, Ghassem R. Asrar, Xuesong Zhang, Chunyang He, and Christopher D. Elvidge. 2015. "A Global Map of Urban Extent from Nightlights." Environmental Research Letters 10(54011).

Zouari, Kamel, Rim Trabelsi, and Najiba Chkir. 2011. "Using Geochemical Indicators to Investigate Groundwater Mixing and Residence Time in the Aquifer System of Djeffara of Medenine (Southeastern Tunisia).” Hydrogeology Journal 19(1):209-19. 